\title{
Geohydrology of North Eastern Province, Kenya
}

\section{GEOLOGICAL SURVEY WATER-SUPPLY PAPER 1757-N}

Prepared in cooperation with the Water Department, Kenya Ministry of Agriculture under the auspices

of the U.S. Agency for International Development

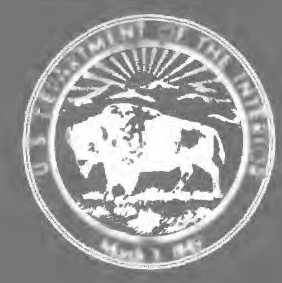




\section{Geohydrology of ${ }^{2} \mathrm{C}^{2}$ ? \\ North Eastern Province,}

\section{Kenya}

By W. V. SWARZENSKI and M. J. MUNDORFF

CONTRIBUTIONS TO THE HYDROLOGY OF AFRICA AND THE MEDITERRANEAN REGION

GEOLOGICAL SURVEY WATER-SUPPLY PAPER 1757-N

Prepared in cooperation with the Water Department, Kenya Ministry of Agriculture under the auspices of the U.S. Agency for International Development

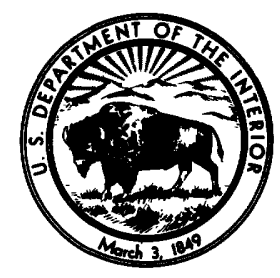


UNITED STATES DEPARTMENT OF THE INTERIOR

GEGIL D. ANDRUS, Secretary

GEOLOGICAL SURVEY

V. E. McKelvey, Director

Library of Congress Cataloging in Publication Data

Swarzenski, Wolfgang Victor, 1917-

Geohydrology of North Eastern Province, Kenya.

(Geological Survey water-supply paper; 1757-N)

Bibliography: p.

Includes index.

Supt. of Docs. no.: I 19.13:1757-N

1. Water, Underground--Kenya--North-Eastern Province. I. Mundorff, Maurice John, 1910- joint author. II. Title. III. Series: United States. Geological Survey. Water-supply paper; 1757-N.

TC801.U2 no. 1757-N [GB1173.K4] 553'.7'0973s [553'.79'0967624] 77-608022

For sale by the Superintendent of Documents, U.S. Government Printing Office Washington; D.C. 20402

Stock Number 024-001-02977-4 


\section{CONTENTS}

\begin{tabular}{|c|c|}
\hline Abstract & $\begin{array}{r}\text { Page } \\
\text { N1 }\end{array}$ \\
\hline troduction & 2 \\
\hline Purpose and scope of project & 3 \\
\hline Previous investigations & 5 \\
\hline Acknowledgments & 5 \\
\hline ographic and cultural features & 6 \\
\hline Location and extent of area & 6 \\
\hline Topography and drainage & 6 \\
\hline Climate & 8 \\
\hline Soils and vegetation & 13 \\
\hline Economic development & 14 \\
\hline drology $-1-0$ & 15 \\
\hline General features & 15 \\
\hline Surface-water storage & 18 \\
\hline ydrogeology & 21 \\
\hline General features & 21 \\
\hline Physical character of rocks and occurrence of ground water & 24 \\
\hline Crystalline rocks (Precambrian or Precambrian(?)) & 24 \\
\hline Mansa Guda Formation (Triassic) & 25 \\
\hline Daua Limestone Series and Mandera Series (Jurassic) & 26 \\
\hline Marehan Series (Cretaceous) & 27 \\
\hline Tertiary and Quaternary deposits, undifferentiated _........ & 28 \\
\hline Merti Beds - & 29 \\
\hline Quaternary deposits & 37 \\
\hline ality of ground water & 41 \\
\hline und-water availability & 42 \\
\hline ture ground-water development & 43 \\
\hline ected references & 44 \\
\hline & 65 \\
\hline
\end{tabular}

\section{ILLUSTRATIONS}

\section{[Plates in pocket]}

Plate 1. Map showing geologic units and potentiometric surface of the Merti aquifer (1973), North Eastern Province and vicinity, Kenya.

2. Map showing distribution of rainfall for four periods during 1971, Mado Gashi-Benane area, North Eastern Province, Kenya.

3. Graphs showing monthly precipitation at Moyale, Mandera, Wajir, and Garissa, Kenya. 
Plate 4. Graphs showing annual departure from average flow and monthly discharge of Ewaso Ng'iro 1949-72, Archers Post, Eastern Province, Kenya.

5. Map showing the location of boreholes and fresh and saline ground-water zones, North Eastern Province and vicinity, north Kenya.

Figure 1. Index map of Kenya showing location of North Eastern Province

2. Map showing mean annual rainfall _..................

3. Graph showing average monthly discharge of Ewaso Ng'iro, 1949-72, Archers Post, Eastern Province, Kenya

\section{TABLES}

TABLE 1. Average annual precipitation at four stations in northeast-

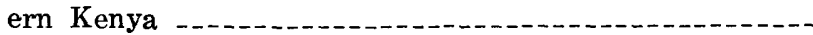

2. Average monthly precipitation at five stations, northeastern

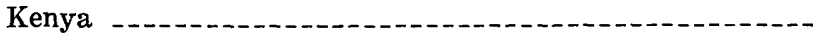

3. Periods of extended drought, Wajir, 1931-72

4. Average annual rainfall, by decade, 1931-60

5. Rainfall at temporary gaging stations, western Mado Gashi area, 1971

6. Specific capacities of boreholes screened in the Merti aquifer

7. Estimated ground-water withdrawals from the Merti aquifer, 1970 and 1973

8. Chemical analyses of waters from boreholes, northeastern Kenya

9. Chemical analyses of waters from shallow dug wells, northeastern Kenya

10. Records of boreholes drilled in Precambrian crystalline rocks, northeastern Kenya

11. Records of boreholes drilled in Mesozoic sedimentary rocks, northeastern Kenya

12. Records of boreholes screened in the Merti aquifer, northeastern Kenya

13. Logs of selected boreholes in northeastern Kenya 


\title{
CONTRIBUTIONS TO THE HYDROLOGY OF AFRICA AND THE MEDITERRANEAN REGION
}

\section{GEOHYDROLOGY OF NORTH EASTERN PROVINCE, KENYA}

\author{
By W. V. Swarzenski and M. J. MundorfF
}

\begin{abstract}
The Government of Kenya, with international assistance, has been engaged since 1968 in a long-term project to develop the livestock resources of the country. Under the first phase of the project, a cooperative agreement between Kenya's Ministry of Agriculture and the U.S. Agency for International Development provided for a survey to evaluate the water resources of the North Eastern Province and for the development of plans for the optimum utilization of range lands and available water resources in selected areas of the province. The present report, largely concerned with ground water, is based on the findings of the water-resources investigation undertaken under Phase I (1968-73) of the project.

The North Eastern Province of Kenya is a perennially water-deficient region of about 127,000 square kilometres. The economy of the province, inhabited by about a quarter of a million nomadic people, predominantly Somali tribesmen, is almost exclusively pastoral, based on the production of livestock. There are no perennial streams within the province, and water supplies for livestock, villages, and small municipalities are obtained from natural ponds, reservoirs, shallow dug wells, and boreholes. During long periods of dry weather, livestock commonly congregate near widely separated permanent watering points and markedly degrade the grass cover within radii of 15 to 20 kilometres. An important aspect of the livestock development project is management of the range to mitigate overgrazing; measures employed are pasture rotation and installation of additional temporary and permanent watering points. In the Mado Gashi-"Kalalut range management pilot study, in an area of 7,300 square kilometres located in the western part of the province, 66 small and large reservoirs individually storing from a few hundred to as much as 40,000 cubic metres of water, and 10 boreholes have been constructed under the project. In addition, the geohydrologic data provided by about 75 boreholes, drilled elsewhere in the province for range management or public supply, provided the basis for delineating zones of fresh and saline ground water and permitted a reconnaissance evaluation of the occurrence of ground water in most of the North Eastern Province.
\end{abstract}


The Merti aquifer, in the northern part of Garissa and the southern part of Wajir Districts, occurs in the semiconsolidated Merti Beds of Pliocene age and constitutes the most important source of ground water in the province. In an area of about 100,000 square kilometres, approximately paralleling the drainageways of the Ewaso Ng'iro and Lak Dera (Lagh Dera) from Habaswein to the Somalia border near Liboi, ground water of excellent quality can be obtained from the Merti aquifer in boreholes drilled to depths of 120 to $\mathbf{1 5 0}$ metres. Moreover, adjacent areas probably exceeding 20,000 square kilometres contain ground water of good to marginal quality that is suitable for use by livestock. Although transmissivities of the aquifer are generally low, there are local areas where properly screened boreholes yield 180 litres per minute or more with drawdowns of 2 to 4 metres.

In the northern part of the province, the results of drilling for water supplies in Precambrian metamorphic or igneous rocks of the basement complex have thus far been disappointing. The majority of boreholes produced less than 9 litres per minute or were dry. The extensive area of Cretaceous sandstone in the eastern part of Mandera District, as yet largely unexplored, seems favorable for future ground-water development. Jurassic sedimentary rocks, found in a large part of Mandera District and in the northern part of Wajir District, have been explored in only a few scattered localities, and in these areas where shale and siltstone predominate. The water-bearing characteristics of the Jurassic limestone are virtually unknown.

\section{INTRODUCTION}

The North Eastern Province (fig. 1) of Kenya is a perennially water-deficient region whose economy is based almost exclusively on the raising of livestock (cattle, camels, sheep, and goats) by nomads, predominantly Somali tribesmen. The Daua ${ }^{1}$ (Daua Parma), a river forming part of Kenya's northern boundary with Ethiopia, carries water perennially except during prolonged droughts; the Tana River, $500 \mathrm{~km}$ (kilometres) to the south, is also a large perennial stream, just $5 \mathrm{~km}$ beyond the southwestern boundary of the province. There are no perennial streams within the North Eastern Province itself, and stock-water supplies are obtained from ponds, pans, and tanks filled during rainy seasons, and from dug wells and boreholes. ${ }^{2}$ Over wide areas water is available only during rainy seasons and for a few weeks thereafter. Because annual dry seasons of 4 to 6 months' duration are the rule, the livestock congregate near the few permanent watering points, greatly damaging or devastating the grass cover within a radius of 15 to $20 \mathrm{~km}$ from permanent water points. In most years, two dry seasons have an aggregate duration of more than 8 or 9 months. Thus, the carrying capacity of the range lands is determined by the availability of water supplies during dry seasons,

\footnotetext{
${ }^{1}$ Geographic names used in this report conform to the usage of the U.S. Board on Geographic Names (1973). Names preceded by asterisk (*) are not verified by BGN.

2 The term "borehole", in Kenya is used synonymously with the term "drilled well."
} 


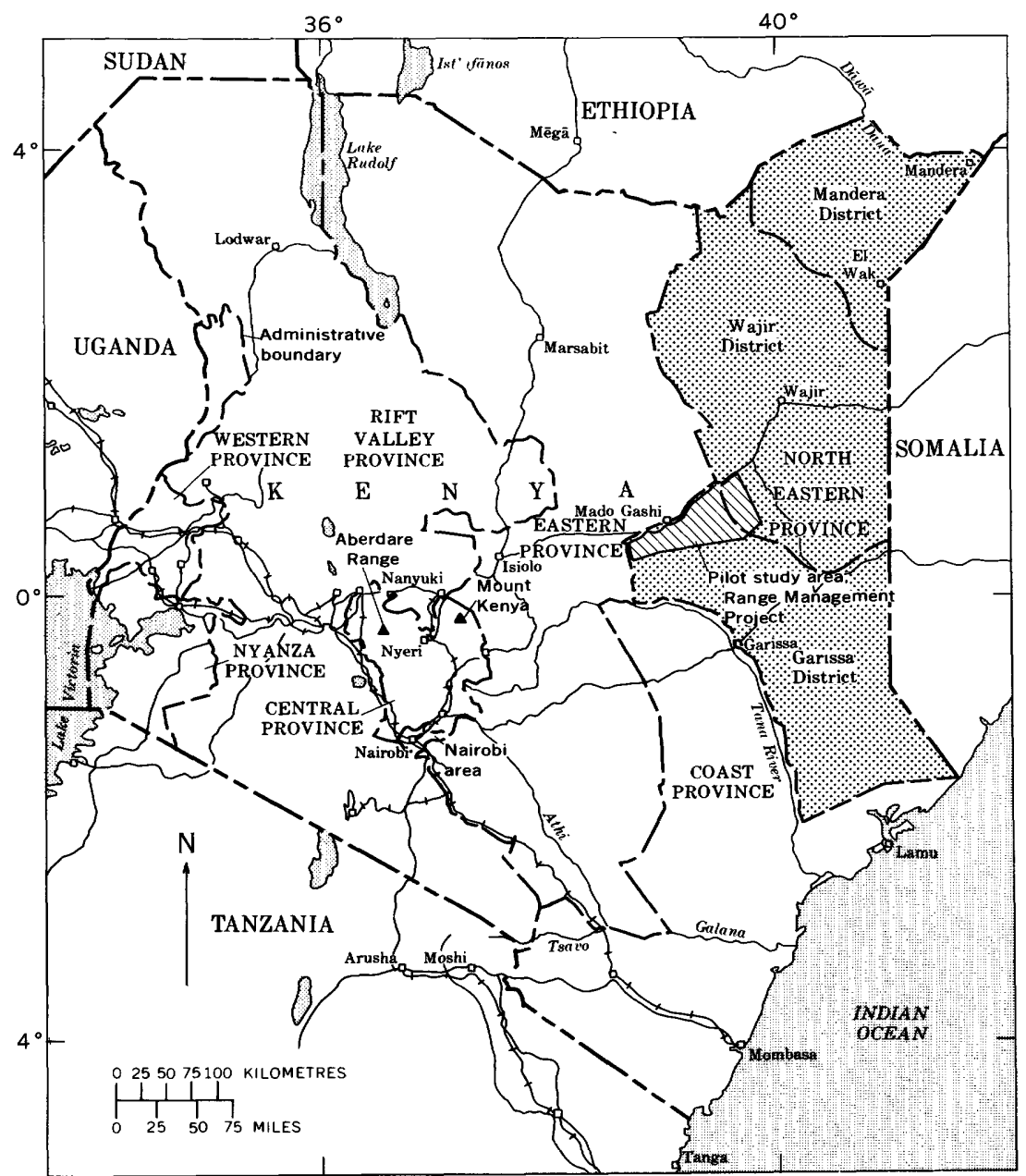

Names and boundary representation are not necessarily authoritative.

Figure 1.-Index map of Kenya showing location of North Eastern Province.

and because of the nonavailability of water supplies, vast areas of good grazing land may remain underutilized.

\section{PURPOSE AND SCOPE OF PROJECT}

The Government of Kenya, with the assistance of loans from the International Development Association, the International Bank for Reconstruction and Development (World Bank), and the Swedish International Development Authority, is engaged in a broad project to develop the livestock resources of the North Eastern Province through extension of dry-season grazing areas by providing additional water points, and through improved mar- 
keting facilities. Under Phase I of the project (Mundorff and others, 1970; Swarzenski and others, 1971) a range management pilot study was undertaken in the Mado Gashi-"Kalalut area of $7,300 \mathrm{~km}^{2}$ (square kilometres) located in the western part of the province. The pilot study emphasized training of personnel, pasture rotation, and construction of stock watering facilities. Physical improvements within the pilot area (fig. 1) included the construction of $1,200 \mathrm{~km}$ of track (roughly graded road), 17 large reservoirs, 49 small reservoirs, and 10 boreholes. The construction of roads, reservoirs, and boreholes was continued in adjacent grazing blocks and also in the Buna area, north of Wajir, during the remaining term of the project. Phase I (1968-73) of the project has now (1973) been completed and is to be followed by Phase II (1974-83), whose goal is increased beef production not only on the communal lands of the North Eastern Province, but also in the Eastern Province and elsewhere in Kenya on commercial and cooperative ranches.

The present investigation of the geohydrology of the North Eastern Province was part of Phase I of the Livestock Development Project, as provided for by an agreement between the governments of Kenya and of the United States of America. The agreement was implemented as a cooperative undertaking of Kenya's Ministry of Agriculture and the U.S. Agency for International Development, and provided for (1) a general survey of the entire province to describe and evaluate the water resources, and (2) detailed studies of selected areas and development of plans for optimum utilization of range lands and available water resources. This report describes the water resources of the province, with particular emphasis on ground water.

In carrying out the geohydrologic studies, consideration was given to needs for supplying water for livestock, stock routes, livestock holding grounds, villages, and larger municipalities. The investigation included: geologic and hydrologic reconnaissance using -maps and aerial photographs; measurement of water levels in boreholes and dug wells; collection and analysis of water samples; and compilation and study of all existing records of boreholes and dug wells. Although no exploratory drilling program was provided under the project, an important element of the investigation was the drilling of 86 boreholes from 1969 to 1973 , largely to meet the immediate needs for stock or village water supplies. The 521st Specialist Team, Royal Engineers, British Army, drilled 18 boreholes, and 68 boreholes were drilled by Crae- 
lius East African Drilling Company within the province, under contract with the Kenya Water Department.

\section{PREVIOUS INVESTIGATIONS}

Ground-water studies in the North Eastern Province, related chiefly to the improvement of existing sources or to the development of local new water supplies, are contained in the files and administrative reports of the Water Department. They include a hydrographical survey of Kenya's Northern Frontier District by Dixey (1944), a report on the geology and hydrology of Wajir District by Bestow (1953), a report on the Lorian Swamp by Arnold (1952) and others. A comprehensive report on the water resources of the Ewaso Ng'iro basin, largely outside of the province, has been published by the Hydraulic Branch, Kenya Ministry of Works (Bestow and others, 1963). Moreover, geological reports by Saggerson and Miller (1957) ; Thompson and Dodson (1958); Joubert (1960); and Walsh (1972) on areas in the northern part of the province, published by the Geological Survey of Kenya, contain borehole $\log _{s}$ and references to the availability of ground water.

\section{ACKNOWLEDGMENTS}

The authors wish to thank E. A. Ngunya, Director, Water Department, Ministry of Agriculture, and officials of the Water Department for their logistic and administrative support in many phases of the investigation. In particular, they wish to thank George A. Classen, former Deputy Director, for his continued support and advice, based on his broad experience in Kenya's northern region, on problems of water supply and range management. Special thanks are due to their friends Simon Wanyeki, Joseph Achieng Onucko, and Haji Ahmed Yusuf of the Water Department, for their assistance in the field under conditions that were always difficult. The Director and staff of USAID provided essential contacts within the ministries and also provided administrative support, which is gratefully acknowledged. Moreover, USAID jointly with the U.S. Geological Survey arranged for the visit of F. J. Pearson, Jr., Geological Survey hydrogeochemist during May 1973, in connection with a program of radiocarbon dating of water samples from the project area, sponsored by both agencies. 


\section{GEOGRAPHIC AND CULTURAL FEATURES}

\section{LOGATION AND EXTENT OF AREA}

The North Eastern Province of Kenya lies between latitude $2^{\circ} 05^{\prime}$ south and $4^{\circ} 16^{\prime}$ north and longitude $38^{\circ} 40^{\prime}$ and $41^{\circ} 52^{\prime}$ east of Greenwich. It contains an area of about $127,000 \mathrm{~km}^{2}$ and is bordered by Ethiopia on the north and Somalia on the east (fig. 1). The maximum extent from east to west is about $260 \mathrm{~km}$ and from north to south is about $710 \mathrm{~km}$. The province comprises the eastern part of the former Northern Frontier District of Kenya and includes three subdivisions, Garissa District $\left(44,000 \mathrm{~km}^{2}\right)$, Wajir District $\left(57,000 \mathrm{~km}^{2}\right)$, and Mandera District $\left(26,000 \mathrm{~km}^{2}\right)$. Each district is named after its principal town, which serves as administrative headquarters. Garissa is headquarters for Garissa District and also the provincial capital. Other important population centers are Dadaab, Liboi, Mado Gashi, Habaswein, Giriftu, Buna, Tarbaj, Takabba, El Wak, "Arabía, and Ramu.

\section{TOPOGRAPHY AND DRAINAGE}

Most of the area of North Eastern Province is virtually level to gently undulating plains rising in altitude to the north where they are interrupted by isolated inselbergs or discontinuous hills and ridges of erosion-resistant rocks. Physiographically, the province can be divided into (1) a northern area of hills and ridges with intervening plains at altitudes ranging from 300 to $1,000 \mathrm{~m}$ (metres) and (2) a southern area of nearly featureless plains, sloping south and southeast from an altitude of about $300 \mathrm{~m}$ to sea level. There is no sharp boundary between these two areas. Moreover, to describe the topography in detail is difficult, because most of the quadrangle sheets (scale 1:250,000) show only form lines and others give only a few spot altitudes.

The northern physiographic area extends to the Ethiopian border in the north and to the Somalia border in the east. Its southern limit extends from the Somalia border approximately along the $2^{\circ}$ north parallel, and the $300-\mathrm{m}$ contour, to Giriftu, northwest of Wajir, thence in a northwesterly direction to the provincial boundary. The broad plains of the northern area are mantled by alluvial sand and silt and reddish sandy soils, underlain at relatively shallow depth by consolidated rock. The plains are interrupted by scattered rocky hills or ridges that have a height ranging from about $75 \mathrm{~m}$ to $750 \mathrm{~m}$ above the general surface of the plains. Approximately the western two-fifths of the northern area consists of Precambrian crystalline rocks of the basement complex (gneiss, 
schist, granite, other metamorphic and igneous rocks) that are buried at shallow depth beneath the plains or that crop out in inselbergs and hill tracts. The eastern three-fifths of the area is underlain chiefly by consolidated sedimentary rocks (shale, siltstone, sandstone, and limestone) of Mesozoic age. These rocks form much more extensive hill tracts than the rocks of the basement complex. Some of these tracts are several kilometres wide and as much as $20 \mathrm{~km}$ long. The hill tracts, particularly in the eastern part of the area, trend northeastward, parallel to the strike of the sedimentary rock strata.

The southern physiographic area includes the rest of the province, from a few kilometres northwest of Wajir to the Indian Ocean near Kiunga (pl. 1). It is a nearly featureless plain, sloping toward the southeast and south from about $300 \mathrm{~m}$ to sea level, at gradients of 0.5 to $0.7 \mathrm{~m} / \mathrm{km}$ (metre per kilometre). Except for a narrow belt of hard Precambrian rocks extending southward from Benane in the western part of the province, the entire area is underlain by semiconsolidated to consolidated deposits of Pliocene to Holocene age. The extensive, nearly level plains are dissected by broad ephemeral drainageways.

The entire province is drained by intermittent streams which generally flow for only a few hours at a time, once or twice a year when rainfall is adequate. 'The drainageways generally are broad and shallow and many are ill defined. A few of the major drainageways are extensive and form fairly well integrated systems that extend entirely across or nearly across the province. These probably were formed during a period of heavier rainfall than today, presumably during the Pleistocene Epoch. During historic time, these drainageways may have carried through-flow perhaps only once in 5- to 10-year intervals. Parts of each drainage, however, may carry some flow during the rainy season.

A small area in the northeast of Mandera District, lying to the north of a line between Fino (Finno) and Derkali, drains eastward and northward to the Daua (Daua Parma). The remainder of Mandera District and Wajir District drain south and east, across the Somalia border. Different segments of the same drainageway are known by names that vary locally. Major southeastward trending drainageways include the Lagh Sure-Lagh Katulo-Lagh Haro, the Laga Badoda (Lagh Badoda), Lak Bor (Lagh Bor), Lagh Bisigh (Lagh Bisiq), the Lagh Bogal, the Lak Dima (Lagh Dima), and the Ewaso Ng'iro-Lak Dera systems.

The boundary between Wajir and Garissa Districts lies along the Ewaso Ng'iro-Lak Dera drainageway, trending in a south- 
easterly direction to near Dadaab, thence in a northeasterly direction toward Liboi, near the Somalia border. The Ewaso Ng'iro is a large river rising on the north flank of the Aberdare Range (fig. 1) and Mount Kenya, but it becomes nonperennial before reaching the North Eastern Province. The Ewaso Ng'iro-Lak Dera drainage includes the Lorian Swamp and other swamps which form a belt generally 6 to $15 \mathrm{~km}$ wide. Only during exceptional floods does water from the Ewaso Ng'iro reach the Somalia border. The northwestern part of Garissa District, south of Benane and Mado Gashi, is drained eastward and northeastward by channels tributary to the Ewaso Ng'iro-Lak Dera system. The drainage of the remainder of Garissa District is not well defined, but is generally to the east and south. A relatively narrow belt, generally 13 to 16 $\mathrm{km}$ wide, paralleling the Tana River, drains south and west to the Tana River.

The Tana River, heading on the south side of Mount Kenya, is the longest perennial stream in Kenya. It flows eastward and southward, discharging into the Indian Ocean south of Lamu. The river lies just outside the province; that is, the provincial boundary has been drawn at a distance of $5 \mathrm{~km}$ north and east of the river except at Garissa, where it reaches the river.

\section{CLIMATE}

The North Eastern Province straddles the equator. Prevailing temperatures throughout the year are generally high, and the climate is semiarid to arid. Mean annual temperatures in most of the province are $28^{\circ}$ to $29^{\circ} \mathrm{C}$, but in the higher areas, along the Ethiopian border and in northern Wajir District, are $6^{\circ}$ to $7^{\circ}$ cooler. Daily temperatures are fairly equitable throughout the year and rarely exceed $40^{\circ} \mathrm{C}$. Over most of the province rainfall is scanty and ranges from 200 to $300 \mathrm{~mm}$ (millimetres) per year, while potential evapotranspiration ranges from 2,200 to more than $2,600 \mathrm{~mm}$ per year. In spite of the great excess of potential evapotranspiration over rainfall (8-10 to 1) there are good stands of grass, moderate to dense bush, considerable internal runoff, and occasional small amounts of ground-water recharge. The fact that excess moisture is available to satisfy these needs is due to the concentration and intensity of storms during some rainy seasons.

Seasonal distribution of rainfall is largely determined by the convergence zone of the northeasterly and southerly monsoons, shifting in response to the movement of high pressure air masses to the north and south. In most of the province, rainfall is concentrated in two seasons, one beginning about the middle of March 
and extending into May, the other beginning in October and extending into December. Precipitation is characterized by extreme variability seasonally and from year to year. In analyzing the precipitation data, records for all stations in the province were utilized, regardless of the period or length of record available. Cumulative rainfall data, from stations for which short-term (8 to 15 years) records are available, were compared with those of the nearest long-term precipitation station (Moyale, Mandera, Wajir, or Garissa). The ratios thus obtained were used to construct an isohyetal map of the province (fig. 2). Relatively ample rainfall, in excess of $500 \mathrm{~mm}$, occurs in a narrow band parallel to the coast and along the Ethiopian escarpment in the vicinity of Moyale. Rainfall decreases toward the centre of the province, most of which has an annual average of 200 to $300 \mathrm{~mm}$. Long-term records are available for three stations within the province; these and data for Moyale, in the Eastern Province, are given in table 1.

Throughout most of the province rain falls almost entirely in the two rainy seasons. In the northern and central parts of the province the period March to May produces the greatest total rainfall, whereas in the southern part maximum rainfall occurs in the period October to December. In the extreme southern part of Garissa District, coastal storms bring heavy rainfall in May and June and some showers during July, August, and September. Average monthly rainfall data for five stations are given in table 2 , which includes the record for Kiunga, characteristic of the coastal belt.

Average annual or monthly data do not adequately portray the nature of rainfall, particularly when extrapolation of scanty data to an area as large as the North Eastern Province is required. Rainfall occurs chiefly in storms of considerable intensity, short duration, and limited areal extent. There are indications that areas that have an altitude above $400 \mathrm{~m}$, as in northern Wajir and Mandera Districts, are favored by higher precipitation. Many typical convectional storms produce rain in areas of only 20 to $50 \mathrm{~km}^{2}$.

TABLE 1.-Average annual precipitation at four stations in northeastern Kenya

\begin{tabular}{|c|c|c|c|}
\hline Station & $\begin{array}{c}\text { Altitude } \\
\text { (metres above } \\
\text { sea level) }\end{array}$ & $\begin{array}{l}\text { Period of } \\
\text { record }\end{array}$ & $\begin{array}{c}\text { Average } \\
\text { annual } \\
\text { precipitation } \\
\text { (millimetres) }\end{array}$ \\
\hline 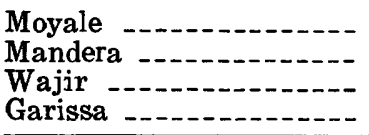 & $\begin{array}{r}1,113 \\
232 \\
265 \\
128\end{array}$ & $\begin{array}{l}1931-72 \\
1937-72 \\
1931-72 \\
1931-72\end{array}$ & $\begin{array}{l}724 \\
247 \\
288 \\
318\end{array}$ \\
\hline
\end{tabular}




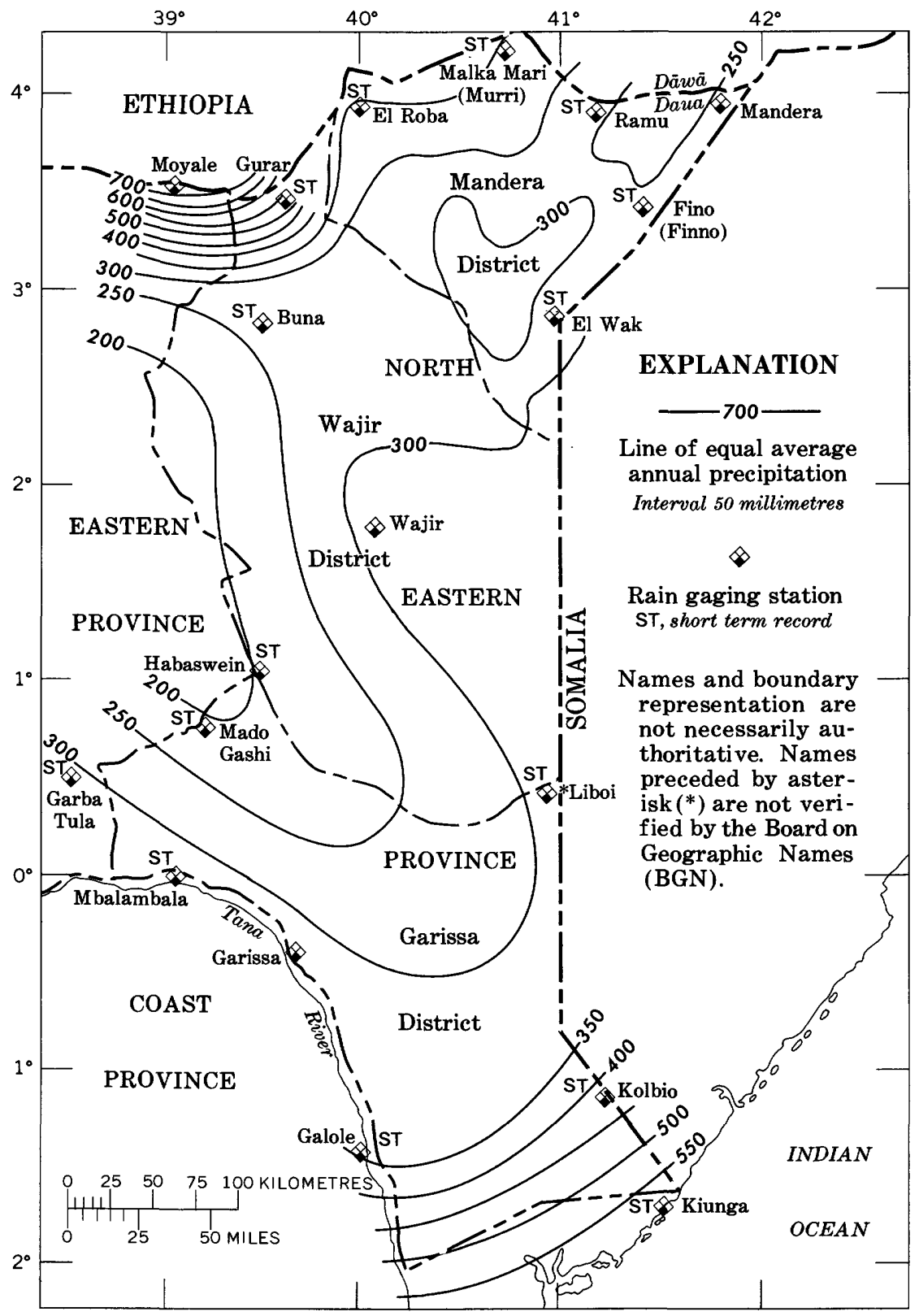

Figure 2.-Mean annual rainfall.

Moreover, more than a dozen of such local storms have been observed from the air at the same time. Thus, even though rainfall is spotty, many areas may receive rainfall from several storms 


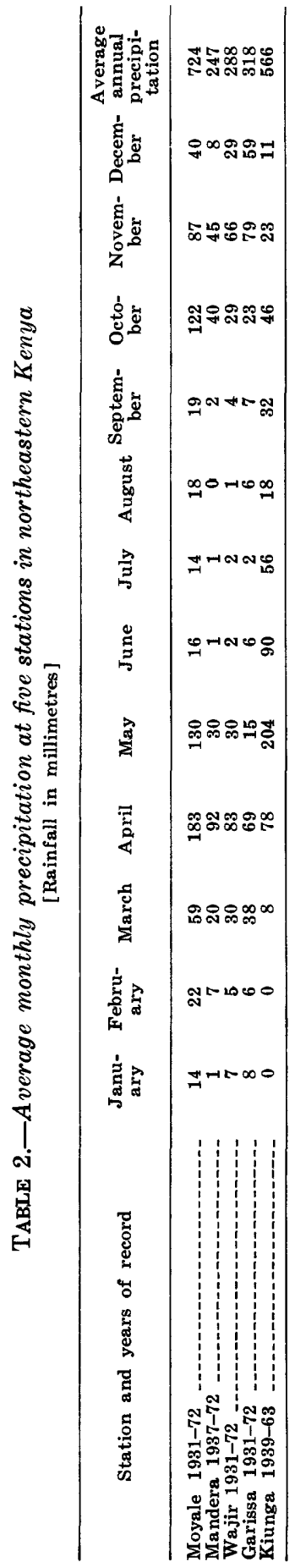


during the course of a season of adequate rainfall. Rainfall produced by individual storms in April and November 1971 was monitored in a relatively small area (pl. 2) of western Garissa District. The data, as related to runoff, are discussed in the section on "Surface-water storage."

Rainfall is extremely variable from year to year, and cycles of several successive dry or wet years are common. This uneven distribution is manifest on the graphs of monthly precipitation at four stations (pl. 3). The graphs show clearly that in many years rainfall in at least one of the rainy seasons is much below average. In some years rains during both wet seasons are much below average. In fact, in some years rains in both wet seasons are so greatly deficient that no runoff is generated for replenishing surface storage. The record at Wajir, centrally located, is probably typical of a large part of the province. Two annual dry seasons are indicated. The longer dry season almost always extends from June through September (4 months) and often includes May and (or) October. The shorter dry season always includes January and February and frequently includes most or all of March. Thus, the normal dry seasons of the year include $21 / 2$ to 3 months at the beginning and about 5 months in the later part of the year. Normal dry seasons and more extended droughts, when the rains failed during one or more successive wet seasons, are shown graphically on plate 3. Extended droughts, of 7 months or longer, at Wajir are listed in table 3 . Months having less than $50 \mathrm{~mm}$ of rain were considered drought months. The table also lists total rainfall during each extended drought. During the period of record, 1931 to 1972, there were three major extended droughts of 22 or 23 months'

TABLE 3.-Periods of extended drought, Wajir, 1931-72

\begin{tabular}{|c|c|c|c|}
\hline Period of drought ${ }^{1}$ & $\begin{array}{l}\text { Duration } \\
\text { (months) }\end{array}$ & $\begin{array}{l}\text { Months } \\
\text { having } \\
25-50 \\
\text { millimetres } \\
\text { rainfall }\end{array}$ & $\begin{array}{c}\text { Total } \\
\text { rainfall } \\
\text { during } \\
\text { period } \\
\text { (millimetres) }\end{array}$ \\
\hline $\begin{array}{l}\text { June 1934-Apr. } 1935 \\
\text { June } 1936-F e b .1937 \\
\text { May 1938-Feb. } 1940 \\
\text { May 1942-Mar. } 1944 \\
\text { May } 1944-A p r .1945 \\
\text { Nov. 1946-Oct. } 1947 \\
\text { Jan. 1949-Mar. } 1950 \\
\text { June 1950-Feb. } 1951 \\
\text { Dec. 1954-Feb. } 1956 \\
\text { May } 1958-F e b .1960 \\
\text { May } 1964-N o v .1964\end{array}$ & $\begin{array}{r}11 \\
8 \\
22 \\
23 \\
12 \\
12 \\
14 \\
9 \\
15 \\
22 \\
7 \\
11\end{array}$ & $\begin{array}{l}1 \\
1 \\
2 \\
3 \\
1 \\
1 \\
1 \\
0 \\
2 \\
2 \\
0 \\
0\end{array}$ & $\begin{array}{r}70 \\
55 \\
233 \\
234 \\
125 \\
76 \\
108 \\
24 \\
125 \\
147 \\
14 \\
123\end{array}$ \\
\hline
\end{tabular}

1 Only periods of 7 months or longer, with monthly rainfall of $50 \mathrm{~mm}$ or less.

Actual drought could have been longer, extending from latter part of preceding month to first part of following month. 
duration; most of the other extended droughts lasted from 11 to 15 months.

It is noteworthy that the longest extended drought at Wajir during the 1960's was about 7 months (table 3). Data available since 1931, exclusive of the years 1940-41, seem to indicate a steady increase in amount of rainfall, decade by decade, at Wajir. Although no clear trend is shown in the record for Garissa, it is obvious that rainfall during 1961-72 was considerably above the 30-year normal given by the East African Meteorological Department for both stations (table 4).

The greatest annual rainfall of record in the province occurred in 1961 and (or) in 1968, when 600 to $920 \mathrm{~mm}$ were measured at many stations. These maxima exceed the amount of least annual rainfall by a factor of 10 to 15 . The fact that rainfall during the 1960's in the North Eastern Province has been greatly above average needs to be taken into account when considering the longterm productiveness of range lands and the quantity of internal runoff available for the development of surface storage.

\section{SOILS AND VEGETATION}

Soils in the province have not been mapped in detail. The geologic maps accompanying the report series of the Geological Survey of Kenya for the Wajir area and farther to the north give some information on the soils in those areas. (See "Selected References.") Soil groups in southern and eastern Garissa District are shown on maps compiled by the British Petroleum Shell Company, which are on file with the Geological Survey of Kenya. In an unpublished report of the Range Management Division, Ministry of Agriculture, Chambers (1969) compiled existing data on soils and, by some field investigation and extrapolation, extended broad soil types into areas previously not mapped.

The different soil types of the area are distinguished on the basis of texture and color. Hard red sandy and clayey soils overlie much of the Precambrian crystalline rocks, north of Wajir. Some of the valleys and broad low-lying plains, however, have gray or brown clayey soils. The Jurassic limestones commonly are over-

TABLE 4.-Average annual rainfall by decade, 1931-60, at Wajir and Garissa [Rainfall, in millimetres]

\begin{tabular}{lccccc}
\hline \multicolumn{1}{c}{ Station } & $1931-40$ & $1941-50$ & $1951-60$ & $\begin{array}{c}\text { 30-year } \\
\text { Normal }\end{array}$ & $1961-72$ \\
\hline Wajir -1 & 200 & 211 & 299 & 237 & 415 \\
Garissa & 313 & 199 & 334 & 282 & 408 \\
\hline
\end{tabular}


lain by gray calcareous silty soils. Almost everywhere within the fine-textured soils are scattered nodules of calcium carbonate. Red sandy soils that transmit water readily generally overlie the sandstones of Cretaceous age, as in parts of Mandera District.

The soils overlying the alluvial deposits west and south of Wajir fall generally into two types, according to source material and subsequent sorting and redeposition: (1) well-drained sandy soils ranging in color from white to red and (2) silty and clayey, poorly drainable soils which are gray to black in color. At places some. of these soils are saline. The gray and black (gray-cotton, blackcotton) soils, where they are not saline, are the most fertile soils in the district and support the best stands of grass.

Typically, most of the province is covered by open or more or less dense bush, alternating with open grassy plains. Large trees, for the most part Acacia species, are found only along drainageways. All vegetation is adapted to survive on a small amount of residual soil moisture or on water obtained from condensation. The vegetation becomes verdant within a week following the rains.

The low and medium bush consists predominantly of species of Acacia and Commiphora, with varying amounts of grass as undergrowth. Where grazing has been heavy the grasses are chiefly annuals and where the grazing has been particularly intense, the undergrowth is chiefly weeds and unpalatable shrubs. Areas remote from permanent water often have a good cover of perennial grasses.

\section{ECONOMIC DEVELOPMENT}

The North Eastern Province, with an area of $127,000 \mathrm{~km}^{2}$, has a population of about 244,000 (Kenya Census, 1969), about 2 people per $\mathrm{km}^{2}$. Population by districts is Garissa, 59,000; Wajir, 90,000 ; and Mandera, 95,000. The town of Garissa, with a population of more than 10,000 , is the largest in the province. It is the provincial capital and also headquarters of Garissa District. Headquarters of the Wajir and Mandera Districts are at Wajir and Mandera, both major towns. Other important settlements and trading centers are: El Wak, Ramu, Takabba, Buna, Gurar, Giriftu, Habaswein, and Mado Gashi.

The economy of the province is almost entirely dependent on the production oi livestock, herded by nomadic tribes. Considerable numbers of milk cows are kept around the major population centers. The cattle population of the province has been estimated at about 600,000 in 1969 (Watson, 1969), with more than one half 
of the total in Garissa District. Of about 290,000 sheep and goats and 180,000 camels, one half are found in Mandera District.

Throughout most of the province rainfall is too scant to permit cultivation of rain-fed crops, and little water is available for irrigation. However, maize, sorghum, and some fruits and vegetables are grown by small-scale irrigation near the Tana River and the Daua, along the southern and northern boundaries of the province, respectively. A few patches of sorghum and maize are also grown at scattered locations elsewhere in the province, but crop failures, even under the most favorable conditions, probably are the rule rather than the exception. Thus, practically all staple foods, except milk and meat, are imported from outside the province.

There is no manufacturing, in the usual sense, within the province. The local inhabitants are ingenious, however, in fabricating many tools and household articles for their own use.

The North Eastern Province has a large population of game animals and birds, which are an important resource for tourist attraction. Moreover, some species of antelope are considered potentially suitable for commercial meat production, as they are resistant to some of the diseases that affect cattle in the province. Little utilization of the wildlife resources has been made in the past, partly because of relative inaccessibility. Undoubtedly, with improvement of roads and with better access by air, much greater use of this resource will be made in the future.

The closest railroad is at Nanyuki, about $220 \mathrm{~km}$ from the nearest point of the province. There are no hard-surfaced roads, and parts of the province are isolated from the rest of Kenya during some rainy seasons. Garissa, Wajir, and Mandera have surfaced airstrips, and there are many other airstrips near villages and police posts that are usually serviceable for small aircraft.

\section{HYDROLOGY}

\section{GENERAL FEATURES}

There are no fully perennial streams in North Eastern Province. The Daua along the Ethiopian border is reported to flow most of the time, except during the most severe droughts. This river is considered a permanent source of supply, as water can usually be obtained by digging in the sandy bed even after surface flow has ceased. The Tana River is a large perennial stream near the southern border of the province. Although it is $5 \mathrm{~km}$ beyond the boundary of North Eastern Province, it is a permanent source of water supply for the people and livestock from the Garissa District. 
The Ewaso Ng'iro, which originates in the high-rainfall regions of Mount Kenya and the Aberdare Range (fig. 1), is perennial as far downstream as Merti. At Archers Post, $150 \mathrm{~km}$ upstream from Merti, the flow has been measured since 1949. Here the runoff averaged 707.8 million $\mathrm{m}^{3}$ (cubic metres) per year from 1949 to 1972. During most of the year, however, monthly discharge is less than 50 million $\mathrm{m}^{3}$, and may decrease to as little as 2 or 3 million $\mathrm{m}^{3}$ in February or March. Periods of high flow are generally April-May and November-December. November is the month of maximum flow, averaging 148.4 million $\mathrm{m}^{3}$ for the 24-year period (fig. 3). In November 1961 the flow was 1,884 million $\mathrm{m}^{3}$, the highest monthly discharge during the period of record. Monthly discharge of the Ewaso Ng'iro and annual departure from average flow at Archers Post are shown on plate 4.

The Ewaso Ng'iro is already an ephemeral stream where it enters the North Eastern Province at Habaswein near the western end of Lorian Swamp. The Ewaso Ng'iro occasionally floods the swamp, which it traverses, and may even sustain temporary downstream flow in the channel of Lak Dera. Flooding of the

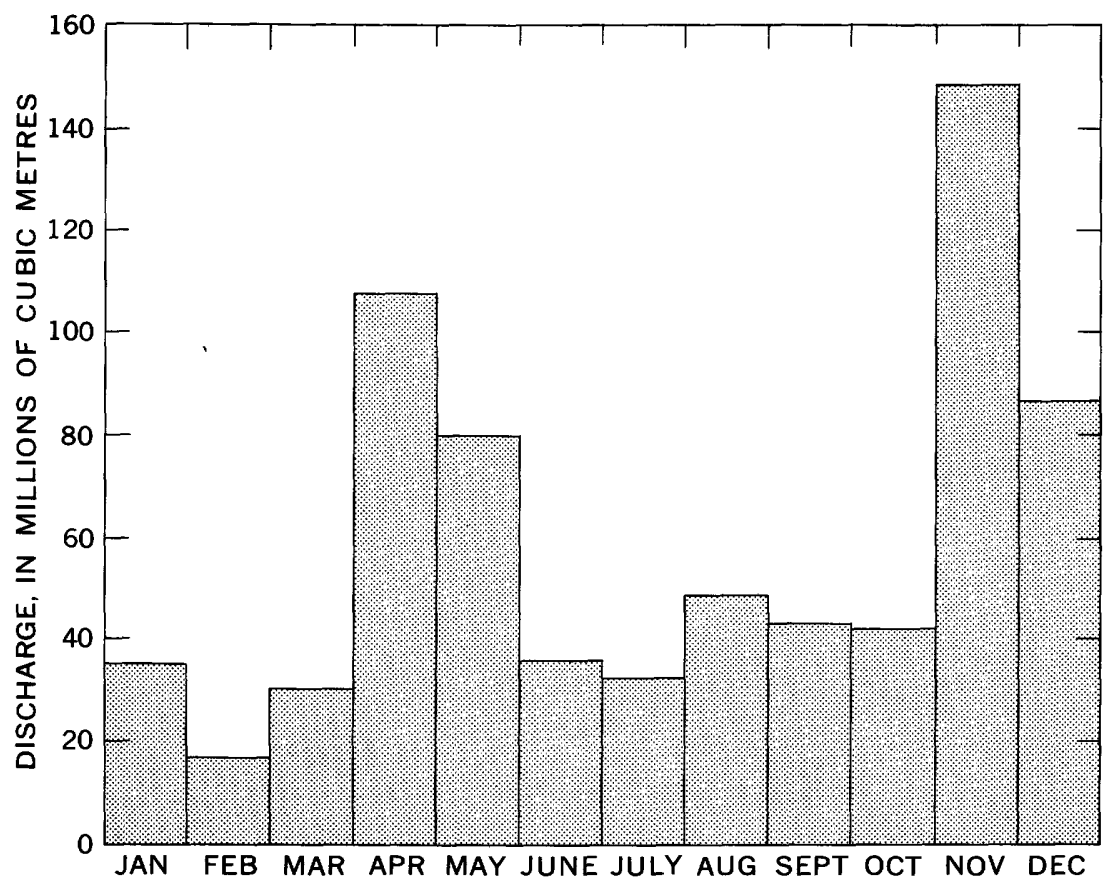

FiguRE 3.-Average monthly discharge of Ewaso Ng'iro, 1949.72 Archers Post, Eastern Province. 
Lorian Swamp and surface flow in the Ewaso Ng'iro as far downstream as Meri was reportedly common prior to 1951 . Flooding became less frequent after 1951, when a shift occurred in the river channel near Merti during a flood. Apparently, the areal extent of the Lorian Swamp is variable, depending on the magnitude and frequency of flooding. Count Wickenburg (1903), who first explored the area in $1901,{ }^{3}$ found the Lorian (meaning "swamp" in the Laigop language). nearly dry and believed that it had no outflow. He also reported no flow in the Ewaso Ng'iro near Sericho, although in some adjacent areas he observed stagnant water. Haywood (1913) estimated the extent of the swamp to be about $150 \mathrm{~km}^{2}$ and noted streamflow in the vicinity of Meri during his journey through the region in $1912 .{ }^{4}$ The extent of the Lorian Swamp apparently has diminished since Haywood's visit. Bestow and others (1963) reported the swamp to cover $101 \mathrm{~km}^{2}$ in 1952 and about $39 \mathrm{~km}^{2}$ in 1959 and 1960 . The Lorian Swamp maintained its swamp vegetation at least until the early 1950's. In recent years (1969-73), however, the vegetation has been indistinguishable from the grassland of adjacent low-lying areas.

Lorian Swamp has been flooded repeatedly since 1951. The record of streamflow at Archers Post, beginning in 1949, is of insufficient length, however, to indicate cycles of high or low flow in the Ewaso Ng'iro that might have affected the Lorian Swamp in the past. Although annual discharge between the peak years of 1951 and 1961 was less than the 24-year average (pl. 4), there were periods of a few days or weeks when flow of the Ewaso Ng'iro reached the Lorian Swamp, as recorded at a temporary gaging station near Habaswein. Flooding was also reported in 1961 and 1968. Streamflow below Habaswein apparently is in response to high rates of discharge at Archers Post, probably in excess of 35 or 40 million $\mathrm{m}^{3}$ per month. Response in flow at Habaswein has been almost instantaneous or considerably delayed, the threshold apparently depending on the volume of antecedent flow.

More recently, flow below Habaswein was observed between September 17 and November 9, 1971. Flow at Habaswein bridge was estimated at about $0.5 \mathrm{~m}^{3} / \mathrm{s}$ (cubic metres per second), diminishing and becoming intermittent after about a week. Flow in a large number of channels and widespread waterlogging were observed upstream from Habaswein, while the area downstream, including the Lorian Swamp, was predominantly water-logged

3 Probably in late September or early October. Authors.

- Probably in mid- or late July. Authors. 
east and west of the main channel, as far south as the area of the Sabena wells, $15 \mathrm{~km}$ from Habaswein (pl. 1). Flow at Habaswein and flooding of the Lorian Swamp, beginning on September 17, 1971, apparently was the result of high rates of flow of the Ewaso Ng'iro from April to August 1971, when monthly. discharge at Archers Post was 37 to 107.3 million $\mathrm{m}^{3}$, the maximum occurring in August. Discharge was 79.5 million $\mathrm{m}^{3}$ in September and remained at about 45 million $\mathrm{m}^{3}$ for the remainder of 1971. Flow at Habaswein virtually ceased, however, in early October 1971, although conditions of water logging persisted downstream.

Other drainageways in North Eastern Province are reported to carry runoff for only a few hours following intense storms. Thus natural and artificial catchments are essential for storage of surface-water supplies in virtually the entire province.

\section{SURFACE-WATER STORAGE}

Several types of surface-water storage are utilized in the province. Hundreds of natural depressions or pans are widely distributed in areas of flat terrain. These usually are formed in areas of clayey and silty soils by wind action (deflation), aided by trampling of animals. Generally, the natural pans are broad and shallow and contain water for no more than a few weeks after rainfall ceases. Dololos are natural depressions in stream channels which hold water for short periods following ephemeral runoff. Artificial reservoirs, locally called tanks, are excavated by hand or machine, generally in natural depressions or drainageways. Dams are constructed across relatively deep and narrow channels, where soil and foundation conditions are favorable. Suitable sites are found in small areas of the northern part of the province. Rock catchments are also utilized in northern areas, where weirs or dams have been constructed across shallow drainageways along the footslopes of bedrock hills or ridges. Rock catchments and dams furnish fairly adequate water supplies at suitable sites in northern Wajir and Mandera Districts, particularly where annual precipitation is relativeiy high $(350-600 \mathrm{~mm})$. In most of the province, however, only reservoirs 6 to $10 \mathrm{~m}$ deep can store sufficient water for use throughout the normal dry season.

The problem of adequate storage for dry-season use, as part of a viable range management plan, has been considered in some detai, by Mundorff and others (1970). In this report R. C. Kornegay estimated the direct runoff from precipitation within the Mado Gashi-*Kalalut range management pilot study area of Garissa District (fig. 1). He concluded that of any rain falling 
within a 5-day period, about $44 \mathrm{~mm}$ would be needed to satisfy antecedent moisture deficiencies and that any excess beyond 44 $\mathrm{mm}$ within a given 5-day period would have the potential for producing runoff. He also concluded that runoff is sufficient during at least one of the two yearly wet seasons to fill proposed reservoirs (the largest of $40,000 \mathrm{~m}^{3}$ capacity) in 8 out of 10 years.

These estimates appear to be realistic when compared to empirical data obtained in Block 1 of the range management pilot study area in 1971. This block, to the west of the Mado GashiGarissa road, has altitudes of 300 to $420 \mathrm{~m}$ and is somewhat favored by its proximity to the crystalline rock hills of the Garba Tula area, having impermeable subsoil, well-integrated drainages, and annual rainfall of 250 to $300 \mathrm{~mm}$. In both rainy seasons of 1971 , rainfall in the area was considerably above average, as recorded at 12 temporary rain-gaging stations.

At station 9 the spring rains, from the end of March to the end of April 1971 produced $258 \mathrm{~mm}$ (table 5). The rains were concentrated in three major storms, one of which produced $169 \mathrm{~mm}$ in a 2 -day period. Individual precipitation records are shown in table 5 ; the location of temporary gages is shown on plate 2. During the storm of April 10 and 11, 1971, only one large reservoir about $5 \mathrm{~km}$ east of station 2 was filled, apparently from runoff produced by about $70 \mathrm{~mm}$ of rain in the immediate vicinity of the reservoir (pl. 2A). A large reservoir $12.8 \mathrm{~km}$ upstream along the same drainageway, Lak Tuglub (Lagh Tugloob), about halfway between stations 1 and 2 remained empty when rainfall in the upper part of the watershed was 29 to $50 \mathrm{~mm}$, or possibly more. The same reservoir, however, filled to about one-quarter of capacity during the storm of April 26, 1971, when about 60 to $78 \mathrm{~mm}$ of rain fell on the watershed (pl. $2 B$ ). During both storms, only a few of the small reservoirs (capacity 450 to $1,000 \mathrm{~m}^{3}$ ) filled wholly or in part. Apparently the spring rains of 1971 were rather localized, as can be seen in table 5 and plate 2 ; perhaps even more localized than suggested by the records of stations that are 8 to $15 \mathrm{~km}$ apart. Table 5 also shows precipitation on April 19 to 21, 1971, when 2 to $45 \mathrm{~mm}$ were recorded. That storm was preceded by 7 dry days and did not produce significant runoff in the area. The total rainfall during March and April 1971 is shown on plate $2 C$.

The rains of November 1971 were ample and concentrated within the week of November 23 to 29. They were more uniformly distributed over the area than the rains of April 1971. Most of the area received from 142 to more than $160 \mathrm{~mm}$ of rain in that week. The record indicates a slight decrease toward the north and west, 


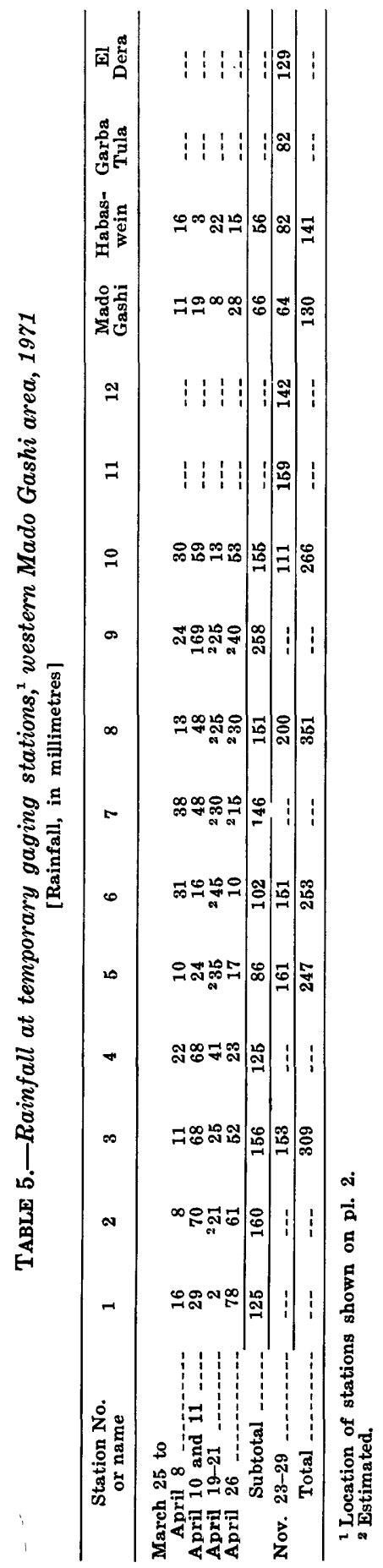


where the upper part of the watersheds received probably between 100 and $120 \mathrm{~mm}$ (table 5). A maximum of $200 \mathrm{~mm}$ was recorded at station 8, about $11 \mathrm{~km}$ southeast of El Dera (table 5). The intense storms of that week, mostly on November 23, 24, and 28, caused runoff to fill all small reservoirs and four of the large reservoirs, while two others, downstream, were partly filled as shown on plate $2 D$.

No actual study of rainfall-runoff relations has been made in the North Eastern Province. Obviously, many other factors are involved in addition to total rainfall. Such factors include storm intensity, distribution of rainfall with time, size of reservoir, character of the soil, antecedent soil moisture conditions, size and slopes of the watershed, vegetation, and others. Obviously, it would be of great benefit if some research were initiated in the North Eastern Province on the rainfall-runoff relationships and on the amount of rainfall required to generate useful storage under various conditions prevailing in the province.

On the basis of present estimates it seems probable that reasonably "permanent" storage would need to provide for at least one deficient wet season; that is, a storage reservoir should hold enough water to last at least 10 or 11 months. Allowances need to be made for evaporation from the reservoir, which probably is at the rate of 200 to $250 \mathrm{~mm}$ per month over much of the province. Moreover, seepage losses need to be considered. Although no actual information is available, such losses may be as high as 50 to $100 \mathrm{~mm}$ per month in areas of sandy soils. Thus, to maintain storage through one deficient wet season, would require provision for a water loss of 3 to $4 \mathrm{~m}$. If the reservoir is to hold sufficient water to carry through two successive wet-season failures, that is for 16 to 18 months, a loss of 5 to $6 \mathrm{~m}$ would have to be assumed.

\section{HYDROGEOLOGY}

\section{GENERAL FEATURES}

The areal distribution of the principal geologic units in the North Eastern Province is shown on plate 1. The oldest rocks consist of metamorphosed sedimentary and igneous rocks of Precambrian age. They include gneiss, schist, quartzite, amphibolite, and granulite. Together with granite, gabbro, and other salic to ultramafic intrusive rocks, they form a basement complex that lies beneath a thin veneer of alluvium and soils in the northwestern part of the province, or protrudes through the veneer in rounded inselbergs or elongated hills and ridges. Although most geologic re- 
ports indicate a Precambrian or Precambrian (?) age for the intrusive rocks, some of these show no evidence of metamorphism, as for example the granite at Takabba, and may have been intruded during the Paleozoic Era.

No sedimentary rocks of positive Paleozoic age have been identified anywhere in the North Eastern Province and that era of approximately 345 million years is recorded in the province only by tectonic events, erosion, and possibly the emplacement of some intrusive rocks. Carboniferous and Permian sedimentary rocks lie between Precambrian rocks in Coast Province and Eastern Province (pl. 1), but their northward extension is concealed by overlying Quaternary and Tertiary deposits.

The Triassic, Jurassic, and Cretaceous sediments were deposited successively in a subsiding basin lying in the northeastern corner of Kenya, the southeastern corner of Ethiopia, and in western Somalia. The center of the basin of Mesozoic rocks lies near El Wak (pl. 1). The strata dip generally at angles of $1^{\circ}$ to $3^{\circ}$ toward the center and subsequent erosion has bevelled the tilted beds, exposing successively older strata at progressively greater distances from the center. Locally, folding and faulting have modified the basically simple pattern of the structural basin. Rocks of Triassic age are represented in the North Eastern Province by the Mansa Guda Formation, which crops out in a narrow band trending north from Tarbaj village to Bur Mayo village. Surface exposures of the formation consist of unfossiliferous sandstone and conglomerate. Drilling at several sites, however, indicates that thick beds of shale and mudstone are an important part of the formation. The Mansa Guda Formation directly overlies rocks of the basement complex and extends southward at least as far as Wajir, where it is overlain by about $120 \mathrm{~m}$ of Tertiary and younger deposits. The Triassic rocks range in thickness from a feather edge to more than 240 m near Tarbaj village.

In the northeastern part of the province, strata of Jurassic age overlie the Mansa Guda Formation. At least two series, the Mandera Series and underlying Daua Limestone Series, and about 10 formations have been described (Joubert, 1960; Ayers, 1952). The Jurassic rocks include limestone, mudstone, shale, and sandstone, lithologies indicative of deposition in a marine or lagoonal environment. Their aggregate thickness was estimated by Ayers (1952) to range from a feather edge to about $2,400 \mathrm{~m}$. The sequence of Jurassic sedimentary rocks covers the largest area and is the thickest of the three sequences of Mesozoic rocks in the 
North Eastern Province. The outcrop area extends $275 \mathrm{~km}$, from east of Wajir northward into Mandera District.

Sandstone, shale, siltstone, and limestone of Cretaceous age are exposed in a semicircular region in Mandera District. These rocks, the Marehan Series, consist of the lower Danissa Beds and an upper sandstone, siltstone, and shale unit representing a complete change in depositional environment from marine in the lower section to continental in the upper section. These strata unconformably overlie Jurassic rocks.

The Tertiary System in the North Eastern Province apparently is represented only by deposits of Pliocene age. Strata of Miocene age, which are not exposed, have been reported, however, from deep test drilling in Garissa District. Pliocene deposits correlated with the Merti Beds crop out in the Benane area and in a strip bordering the Tana River. Elsewhere, Pliocene strata are overlain by a relatively thin veneer of soils or Quaternary alluvium. The Merti Beds or their equivalent, extend southward from Giriftu and Tarbaj village through southern Wajir District and apparently through most of Garissa District. The strata generally consist of interbedded clay, sand, and weathered gravel in a clayey matrix, largely derived from erosion of the basement rocks to the west.

Tertiary or Quaternary volcanic rocks, consisting of two lava flows of olivine basalt crop out extensively in the eastern part of the Eastern Province from about $25 \mathrm{~km}$ south of Moyale south to the latitude of Wajir. These flows also extend a short distance into the extreme western part of Wajir District (pl. 1). Because the older flow seems to rest on the late Tertiary erosional surface of the region, it has been referred to the Pleistocene by Walsh (1972), who considers the younger flow to be also of Pleistocene or possibly Holocene age. Two similar lava flows capping the Merti Beds at Merti, in the Eastern Province, are considered to be of late Pliocene age by Matheson (1971). It seems likely, however, that the lava flows in both localities are of the same age. The lava flows capping the Merti Beds are probably related to volcanism in the Nyambeni Range, northeast of Mount Kenya, during the Pleistocene.

The Quaternary System is represented by deposits of both Pleistocene and Holocene age. Pleistocene deposits are widespread in the northern area of the province. In the vicinity of Wajir they include surface deposits of arenaceous limestone, calcareous sandstone, marl, and gypsum. Limestone and gypsum of Pleistocene age occur near the surface in a circular area surrounding El Wak. The Wajir and El Wak Beds were deposited in an arid to semi- 
arid environment by shallow streams or in playas and lakes, and they reflect climatic variations during the Pleistocene, including periods of rainfall greater than at present. Terraces along the Tana River and the Daua and some of the calcretes overlying the Merti Beds may also be of Pleistocene age.

Alluvial sand, silt, and clay, probably ranging in age from late Pleistocene to the Holocene, occur along many of the present drainageways. The most important of these are the Ewaso Ng'iro, Daua, Tana River, Galana Gof, Lak Bor, and Lagh Katulo. Probably 90 to 95 percent of the province has soil cover of a few centimetres to several metres, ranging from red sandy soils to black or gray clayey soils. Some of the soils have developed by weathering of the older rocks, but most have developed on Pliocene or younger deposits.

Because of the extensive soil cover it was not possible to map the Merti Beds separately from the younger Quaternary deposits; consequently they are shown together on plate 1 as undifferentiated Quaternary and Tertiary deposits.

\section{PHYSICAL GHARACTER OF ROGKS AND OCGURRENGE OF GROUND WATER}

\section{CRYSTALLINE ROCKS (PRECAMBRIAN OR PRECAMBRIAN(?))}

Crystalline rocks of a basement complex of Precambrian age or Precambrian(?) occur in the hills and ridges in the north and west of the North Eastern Province or at shallow depths beneath surficial deposits in the areas north and northwest of Giriftu (pl. 1 ). They are predominantly granite, granite gneiss, and biotite schist, with minor occurrences of other igneous or metamorphic rocks. Small quantities of ground water are obtained at favorable sites from joints and fractures in granitic rocks or from cleavage planes in metamorphic rocks. Successful boreholes, yielding 25 to more than $100 \mathrm{l} / \mathrm{min}$ (litres per minute) generally tap zones of weathered rock that may be as much as 50 to $100 \mathrm{~m}$ thick. Favorable sites are upgradient from faults or buried ridges, as borehole C-3541 near Halati (Helati) (pl. 5), or in areas where the potential for recharge from runoff down adjacent hill slopes is high. While careful siting of boreholes, perhaps aided by geophysical exploration, could reduce the number of failures, the degree of permeability of the weathered zone is a fortuitous element that controls individual borehole yields. Yields of 50 and $150 \mathrm{l} / \mathrm{min}$ from two of the most productive holes (C-3541, C-3899) apparently are due to the presence of calcareous concretionary zones 
within the upper part of the zone of weathering; permeability in these zones presumably is enhanced by solution cavities.

The results of drilling for water supplies in most of the crystalline rocks of the basement complex have been generally disappointing. Of 30 boreholes drilled since 1968, 22 have yielded less than $9 \mathrm{l} / \mathrm{min}$ or were dry. The yields of eight boreholes ranged from 14 to $150 \mathrm{l} / \mathrm{min}$, but two of these failed during periods of prolonged drought. The great variability of yield and water quality within short distances is indicative of localized recharge. Although there are isolated pockets of salty water, most of the boreholes drilled in the crystalline rocks yield water that is satisfactory for stock use. Records of boreholes drilled in these rocks are shown in table 10 ; chemical analyses are given in table 8; and selected geologic $\log$ in table 13. The location of boreholes is shown on plate 5 .

\section{MANSA GUDA FORMATION (TRIASSIC)}

The Mansa Guda Formation has been described by Ayers (1952) as sandstone and conglomerate that underlie a Jurassic succession of limestones. The formation was assigned a Triassic age by Thompson and Dodson (1960) because of resemblance to similar rocks of Triassic age in Ethiopia and Somalia. Consolidated quartzose conglomerate and sandstone of the Mansa Guda Formation are well exposed in the hills of Mansa Guda and Tarbaj and crop out in a narrow band extending northward from Tarbaj village to Bur Mayo village, on the Wajir-Takabba road. In the area south of Tarbaj village the Mansa Guda Formation is mantled by soils or covered by younger rocks. The Mansa Guda Formation was also penetrated in borehole C-3918 $29 \mathrm{~km}$ northeast of Giriftu at a depth of $7 \mathrm{~m}$ and apparently is present at relatively shallow depth as far south as Wajir. Two boreholes (C-3155 and C-3306), drilled in Wajir during the early 1960's to depths of 186.4 and $263 \mathrm{~m}$, respectively, penetrated shale, siltstone, and sandstone, beginning at a depth of $120 \mathrm{~m}$; this part of the section appears to be part of the Mansa Guda Formation. These boreholes yielded, respectively, only 17 and $22 \mathrm{l} / \mathrm{min}$ of water and were abandoned. An attempt to tap a downdip extension of the permeable beds exposed in Tarbaj Hill was made in borehole C-3569 (Selby, 1969) but failed to find water at $113 \mathrm{~m}$. More recent drilling near Tarbaj village and Mansa Guda village has revealed that siltstone and shale predominate within the depths penetrated, which were $182 \mathrm{~m}$ at Mansa Guda (C-3690) and $241 \mathrm{~m}$ at $\mathrm{C}-3668,5 \mathrm{~km}$ northeast of Tarbaj. The latter borehole was dry, although it bottomed at 
$120 \mathrm{~m}$ above sea level, which is considerably below the expectable water level in the area.

Most of the boreholes thus far drilled in the Mansa Guda Formation have been dry. The deep boreholes drilled in Wajir, previously mentioned, and one south of Dambas yielded small amounts of moderately mineralized water of sodium chloride type (tables 8 and 11). Exploration of the water-bearing potential of the Mansa Guda Formation has been hampered by the lack of access roads for drilling rigs and by the difficult terrain to the east of the Tarbaj-Takabba road. No boreholes have yet (1973) been drilled within the entire area of Triassic rocks north of Mansa Guda village.

Chemical analyses of water from boreholes drilled in Triassic rocks are included in table 8 . Records of boreholes in Triassic rocks are given in table 11 .

\section{DAUA LIMESTONE SERIES AND MANDERA SERIES (JURASSIC)}

Sedimentary rocks of Jurassic age that directly underlie the surface of a large part of Mandera and the northern part of Wajir Districts include the Daua Limestone Series and the overlying Mandera Series (pl. 1). The aggregate thickness of the Jurassic rocks is estimated by Ayers (1952) to be about 2,400 m. The Daua Limestone Series includes fossiliferous well-bedded to massive limestone of gray, buff, or brown color with intercalated argillaceous limestone and shale. The rocks of the overlying Mandera Series are similar, but contain a larger proportion of sandstone. Both series include variegated gypsiferous shales. The Jurassic strata are in contact with conglomerate of the Triassic Mansa Guda Formation at Didimtu (Didimtu Hill), about $8 \mathrm{~km}$ south of Bur Mayo and are believed to overlie the Triassic to the east of the contact shown on plate 1 . The Jurassic rocks dip gently east, southeast, south, and southwest at angles of $2^{\circ}$ to $3^{\circ}$ toward the center of the structural basin in Mesozoic rocks at El Wak (pl. 1).

The ground-water potential in the large outcrop area of Jurassic rocks is not well known. In boreholes drilled at six widely scattered localities the rocks were predominantly shale with minor amounts of limestone and sandstone. One borehole (C-3686) at Aus Manduli yielded $17 \mathrm{l} / \mathrm{min}$ from siltstone and shale; another (P-160) yielded less than $6 \mathrm{l} / \mathrm{min}$ from limestone. Boreholes at Wajir Bor, Wel Garas (Wal Giris), and east of Takabba (P-146, C-3828, C-3507, table 11) penetrated limestone and shale of the Daua Limestone Series. These boreholes were reported dry or of a yield insufficient to merit completion. Borehole $\mathrm{C}-3574$ north of Fino 
penetrated siltstone of the Mandera Series. Bailer tests indicated that the yield of the borehole may be as high as 50 to $75 \mathrm{l} / \mathrm{min}$. Lithology and water-bearing characteristics of the Jurassic rocks, like those of the Triassic rocks, are only known from a few isolated drill sites, and large areas remain yet (1973) to be explored by further drilling.

Chemical analyses of waters from boreholes tapping Jurassic rocks are given in table 8 . Records of boreholes in Jurassic rocks are given in table 11 .

\section{MAREHAN SERIES (CRETAGEOUS)}

Sandstone, shale, and siltstone of Cretaceous age occupy the central part of the structural basin in Mesozoic rocks centered at El Wak and are prominently exposed where they cap the hills and ridges of eastern Mandera District. These rocks, which commonly weather to a reddish color, are of continental origin; they belong to the upper part of the Marehan Series, whose lower part is known as the Danissa Beds (Saggerson and Miller, 1957). Lying unconformably on the Jurassic, the Danissa Beds mark a regression of the Jurassic seas. Their lithologic character is variable, indicating a change from marine to estuarine, to deltaic, and to terrestrial conditions. The Danissa Beds consist generally of lenses of interbedded limestone, shale, siltstone, and sandstone. Joubert (1960) reports the Danissa Beds are about $116 \mathrm{~m}$ thick, whereas the overlying sandstone, shale, and siltstone unit of the Marehan Series is about $107 \mathrm{~m}$ thick. Rocks of the Marehan Series generally $\operatorname{dip} 2^{\circ}$ to $3^{\circ}$ to the east, southeast, south, and southwest toward El Wak, but dips are variable and may locally be much steeper as the result of folding and faulting.

Ground water of acceptable quality and from comparatively shallow depth has been obtained in three areas from rocks of the Marehan Series. Boreholes producing the highest yields are in the Fino area, along the road from El Wak to Mandera. They yield from 40 to $90 \mathrm{l} / \mathrm{min}$, apparently from upper sandstone unit of the Marehan Series. The sandstone from the boreholes is white, pink, and reddish in color, of fairly well-rounded quartz grains, and friable, fine- to medium-grained texture. This sandstone also seems to be a promising aquifer in other areas (Mundorff and Swarzenski, 1969). Boreholes drilled at *Asahaba and War Gedud (Wergedud) yield from 14 to $50 \mathrm{l} / \mathrm{min}$ apparently from finegrained siltstone and shale that may be correlated with the Danissa Beds of the Marehan Series. Geologic maps that include the *Asahaba and War Gedud areas (Joubert, 1960; Saggerson and 
Miller, 1957) indicate faults which may at places affect the distribution of aquifers and impede or facilitate movement of ground water.

Of 20 boreholes drilled in Cretaceous sandstone and siltstone, 10 yielded individually more than $13 \mathrm{l} / \mathrm{min}$. Two other boreholes apparently were not drilled deep enough to tap saturated sandstone. Extensive areas of Cretaceous sandstone in eastern Mandera District, as yet largely unexplored, seem favorable for future ground-water development.

Chemical analyses for waters from boreholes tapping Cretaceous rocks are given in table 8. Records of boreholes in Cretaceous rocks are given in table 11 .

\section{TERTIARY AND QUATERNARY DEPOSITS, UNDIFFERENTIATED}

The Merti Beds of late Pliocene age extend beneath the plains of southern Wajir District and most of Garissa District and constitute the major stratigraphic unit of North Eastern Province. Named from their outcrops at Merti, in the Eastern Province, the Merti Beds have been described in outcrop and mapped in a comparatively small area north and south of Garba Tula by Matheson (1971). Other exposures of the Merti Beds are rare, but the upper part of the Merti Beds can be seen in bluffs near Mado Gashi, in the banks of the Galana Gof and other drainage channels, and at many reservoir sites southeast of Habaswein, where thin overburden has been removed during construction. Much information concerning the Merti Beds has been obtained from well logs and core samples taken during recent drilling; it appears that the Merti Beds or equivalent strata underlie virtually all of the southern and southeastern part of the province. Also the unconsolidated valley fill of some of the northern plains near the Ethiopian border that include gravel and lateritic horizons, may be of late Pliocene age.

Deposits of Quaternary age include Pleistocene lacustrine sediments in the vicinity of Wajir, and around El Wak as well as Pleistocene (?) and Holocene alluvial sediments in the channels of the major watercourses of the province and in narrow adjacent flood plains. Because of similar lithology, thick soil cover, and low relief, it was not feasible to distinguish the Tertiary and Quaternary deposits in mapping. Consequently on plate 1, they are shown together as undifferentiated Quaternary and Tertiary deposits.

Tertiary or Quaternary basalt flows which are exposed in the northwestern part of North Eastern Province may be water bearing, but their potential is unknown. Their limited extent and 
presumably shallow depth suggest that they are unlikely to be important aquifers in the province.

\section{MERTI BEDS}

The late Pliocene Merti Beds of red, white, gray, or tan color include friable to semiconsolidated gravel, grit, sand, silt, and clay, generally intercalated in lenticular beds. Their variable thickness, extent, and lithologic character suggest rapid deposition of detrital materials derived from the erosion of adjacent areas of older rocks. In the western part of Garissa District for example, the gravel may be derived from crystalline rocks, or the source rock may be Jurassic limestone, as in the Khot Khot and lower Lak Dera areas. The gravel commonly occurs in a clayey matrix and pebbles show evidence of in situ weathering. There are also scattered concretionary zones, commonly less than $1 \mathrm{~m}$ thick, of silt, sand, and gravel cemented by calcium carbonate. Although the bulk of the deposits is rather impermeable, appreciable amounts of fresh to brackish ground water can be obtained from boreholes screened in the more permeable zones of the Merti Beds. This unit contains the principal and most productive aquifer of North Eastern Province.

The Merti aquifer extends from northeast of Habaswein to the Somalia border at Liboi and beyond into Somalia; it is approximately in line with the drainageways of the Ewaso Ng'iro and Lak. Dera. Its lateral boundaries are not well defined at present (1973) but coincide approximately with the edge of adjacent saltwater bodies, as indicated by the $10,000 \mathrm{mg} / \mathrm{l}$ (milligrams per litre) line of equal dissolved solids shown on plate 5 . Beyond the limits indicated, the Merti Beds are predominantly clayey, yielding little or no water. Such water as can be obtained from the clayey beds generally is salty, containing from 10,000 to 15,000 $\mathrm{mg} / \mathrm{l}$ of dissolved solids. To the southwest, the source of the extensive clays in the Merti Beds is chiefly disintegrated crystalline rocks of the basement complex, whereas to the northeast the source presumably is weathered shales, a major component of the Triassic and Jurassic rocks east and northeast of Wajir. The clayey and sandier zones within the Merti Beds, and their inferred relation to bedrock are shown on plate 1, a geohydrological profile from Garba Tula to Aus Manduli. Plate 5 also illustrates, schematically, the position of the fresh ground-water zone near Habaswein, centrally located in an area where the Merti Beds include a relatively large proportion of sand. 
The extensive fresh-water zone of the Merti aquifer that has water containing less than $1,000 \mathrm{mg} / \mathrm{l}$ of dissolved solids follows approximately the alinement of the Ewaso Ng'iro and Lak Dera channelways. It includes the Lorian Swamp area, but also part of the adjacent higher areas to the northwest. This zone is about 200 $\mathrm{km}$ long, extending southeastward from Habaswein to Liboi. Its width ranges from about 20 to $90 \mathrm{~km}$ and it is widest at the Kenya border with Somalia, near Liboi ( $\mathrm{pl} .5$ ). Thus, in an area of approximately $10,000 \mathrm{~km}^{2}$ water of good quality can be obtained from properly constructed boreholes. Moreover, adjacent areas probably exceeding $20,000 \mathrm{~km}^{2}$ are underlain by water of good to marginal quality that is suitable for use by cattle. The ground water contained in the Merti Beds is one of the chief economic assets of the North Eastern Province.

In the area of the Merti aquifer, ground water is found at rather uniform depths of about $90 \mathrm{~m}$ in the low-lying areas, and at depths of as great as $140 \mathrm{~m}$ in areas of higher altitude. Successful boreholes tap the more permeable zones of the Merti Beds, commonly between depths of 105 to $150 \mathrm{~m}$ below land surface. The ground water is generally confined, and potentiometric heads may be several metres higher than the top of the saturated sand beds. Boreholes screened in fine silty sand commonly yield 30 to 75 $1 /$ min, with considerable drawdown. Many of the boreholes, however, yield 100 to $180 \mathrm{l} / \mathrm{min}$, with comparatively little drawdown $(2-4 \mathrm{~m})$, as in the Habaswein and Liboi areas, where the aquifer consists of sand and gravel. In these and other areas withdrawal rates were limited by the capacity of piston-type pumps, set in 152-mm casing, that were available for testing. Higher yields could have been obtained with electric submersible or turbine pumps. Specific capacities of boreholes tapping the Merti aquifer range from about 2 to $90(1 / \mathrm{min}) / \mathrm{m}$ (litres per minute per metre of drawdown), as shown in table 6 .

Commonly, the beds of water-bearing sand and gravel in the Merti aquifer are 10 to $15 \mathrm{~m}$ thick and apparently are of limited lateral extent. Transmissivities of the aquifer can be estimated from specific capacity data of boreholes. They range from about 6 to $120 \mathrm{~m}^{2} / \mathrm{d}$ (metres squared per day). Hydraulic conductivities, similarly estimated, are in agreement with the very fine to medium grain sizes of much of the aquifer material and range from 0.25 to $4.0 \mathrm{~m} / \mathrm{d}$ (metres per day). In areas where the aquifer material is coarse sand and gravel, hydraulic conductivities may be as high as $12 \mathrm{~m} / \mathrm{d}$. 
TABLE 6.-Specific capacities of selected boreholes screened in the Merti aquifer

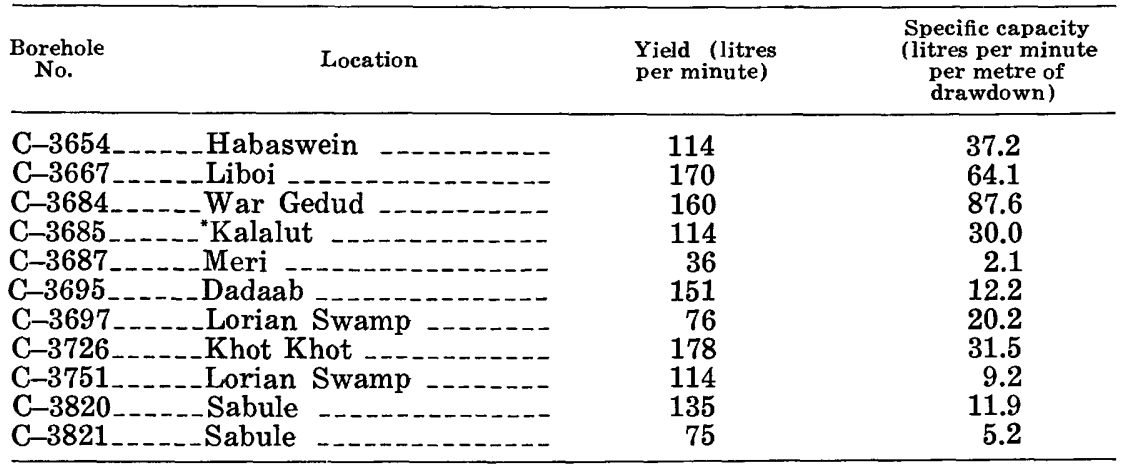

The potentiometric surface of the Merti aquifer shown on plate 1 is based on altitudes determined by barometer, using the refer ence datum of $198.12 \mathrm{~m}$ at the bridge crossing the Ewaso Ng'iro about $3 \mathrm{~km}$ southwest of Habaswein. Thus contours are approximate only. The contours indicate that the fresh ground water moves toward the southeast at gradients of $0.4: 1,000$ to $1: 1,000$, the lowest gradient prevailing near the Somalia border. Along the Lorian Swamp-Lak Dera trend the contours are generally convex to the northwest. Contours above $100 \mathrm{~m}$ are not well defined by existing data. There are, however, indications of considerably higher heads and steeper gradients in the adjacent salt-water zones, as evidenced by heads of $148 \mathrm{~m}$ in borehole C-3822 south of Sericho and $267 \mathrm{~m}$ in borehole C-96 at El Dera. Analogous conditions are believed to exist in the salty ground-water zone northeast of Lagh Bogal (pl. 5). If the spatial distribution of hydraulic conductivity of the system were isotropic, ground-water flow would be in the direction of the steepest gradient; under these conditions saline ground water to the northeast and southwest would be moving toward the fresh water in the Lorian SwampLak Dera region. Hydraulic conductivities in the fresh-water zone of the Merti aquifer probably exceed those of the clays in the Merti Beds by a factor of $\mathbf{1 0 0}$ or more. It can thus be assumed that the salty ground water flanking the fresh-water zone is essentially stagnant under present conditions and that the higher heads found in the saline zones reflect differences in hydraulic conductivity.

The velocity of fresh water moving southeastward in the Merti aquifer can be determined from the gradients indicated on plate 1 $(0.4: 1,000$ to $1: 1,000)$ and from hydraulic conductivities that may have average values of 3 to $10 \mathrm{~m} / \mathrm{d}$. Thus velocities of 2 to $12 \mathrm{~m}$ per year are indicated throughout the area of the aquifer. 
The 15-m contour (pl. 1) virtually parallels the Somalia border, indicating ground-water underflow toward Somalia at low gradients. The thickness of saturated sediments in the area is not known, as boreholes at and near Liboi penetrated only the uppermost few metres of sand and gravel. As water levels in the area are only 12 to $15 \mathrm{~m}$ above sea level, the saturated thickness may not be great, perhaps 40 to $60 \mathrm{~m}$. The amount of fresh water leaving the area can be calculated by the formula $Q=P I A$, assuming the average hydraulic conductivity, $P$, to be $5 \mathrm{~m} / \mathrm{d}$, the gradient, $I$, to be $0.4: 1,000$; and the area of discharge, $A$, to be $40 \mathrm{~m}$ $\times 90,000 \mathrm{~m}$. Thus, the amount of underflow near Liboi, across the $90-\mathrm{km}$ width of the fresh-water zone, would be $7,200 \mathrm{~m}^{3} / \mathrm{d}$ (cubic metres per day). If a saturated thickness of $60 \mathrm{~m}$ is assumed, it would be $10,800 \mathrm{~m}^{3} / \mathrm{d}$. Another small amount should be added to these estimates of underflow to allow for brackish water that moves also eastward from adjoining areas.

The low altitude of the potentiometric surface of the Merti aquifer near Liboi and very low gradients that apparently decrease in the border area and beyond are puzzling in view of the fact that Liboi is about $180 \mathrm{~km}$ distant from the Indian Ocean. In Liboi the depth to water in the main aquifer is $91 \mathrm{~m}$, and there are no zones of perched or semiperched water above this level. The depth to water decreases toward the east, in Somalia, presumably to a point where ground-water discharge by evapotranspiration is the dominant feature of the system. Moreover, there may be reversed ground-water gradients from the coastal zone toward the drier interior lowlands, which would also contribute ground water to the postulated discharge area or areas. These would be characterized by saline ground water and by gradients that have substantial vertical components. Thus, large amounts of ground water may be intercepted in sink areas before reaching the Indian Ocean. These discharge areas may have their own controlling base levels, independent of sea level. It is interesting to note that water levels which appear to be several metres below sea level have been reported in abandoned boreholes in the Kolbio area in southern Garissa District near the Somalia border (pl. 5; C-2718, C-2719, table 12). This report, however, could not be verified.

The question as to whether and at what rate fresh ground water in the Merti aquifer is being replenished under present climatic conditions cannot be answered adequately on the basis of existing data. In view of the low permeability of most of the deposits underlying the area, recharge by direct percolation of rainfall is probably small or negligible. Available data are sparse 
and do not include water-level records that might be indicative of periodic fluctuations or trends. Infiltration from runoff in streams tributary to the Lorian Swamp-Lak Dera drainageways, possibly augmented in small measure by underflow from the northwest, is the most likely source of recharge, consonant with observable facts.

Infiltration of rainfall can only occur after moisture deficiencies in the soil have been met by a succession of rainy days. The amount required to meet the deficiencies varies with antecedent conditions, but it is probably close to $40 \mathrm{~mm}$. Only the amount of rainfall in excess of about $40 \mathrm{~mm}$ in any rainy period has the potential of providing recharge. Bestow, in his study of the Wajir area (1953), assumed a limit of $32.5 \mathrm{~mm}$ and calculated recharge to the shallow water-table aquifer only from the days on which rainfall exceeded that amount. His study from 1942 to 1951, a period of deficient rainfall, indicated potential recharge on only 11 days during the 10-year period. Although these estimates may be low, long-term rainfall data show that there are many years when total monthly precipitation during the rainy season is little more than $50 \mathrm{~mm}$, and the small amount of rainfall during these years probably precludes any possibility of recharge. No doubt the potential for infiltration is high during periods of prolonged and intense rainfall, such as have occurred several times between 1961 and 1972 (pl. 3). It is not known, however, to what extent these rains may have provided recharge to the Merti aquifer through 90 to $100 \mathrm{~m}$ of rather impermeable materials. The only indication of changes in water level was found in a borehole at Habaswein, $\mathrm{C}-3218$, where the water levels measured in 1970 and 1973 were $1.2 \mathrm{~m}$ higher than those locally reported in 1963. Replacement boreholes drilled in 1972 and 1973 at Hagadera, Alinjugul, and Liboi indicated that water levels or the depths to the first water encountered were essentially the same as those reported in the initial installations of 1940 and 1957.

Seepage losses from the Ewaso Ng'iro, upstream from Sericho, where it normally goes dry, have been considered a major source of recharge to the Merti aquifer. H. Humphries and Sons (1958) in a report to the Government of Kenya estimated losses for different reaches of the river from *Melka Bulfayo, near Merti, where it leaves its bedrock channel, to Habaswein. The estimated losses were heaviest in the upstream area and averaged about $180,000 \mathrm{~m}^{3} / \mathrm{d}$, or about $1,000\left(\mathrm{~m}^{3} / \mathrm{d}\right) / \mathrm{km}$ (cubic metres per day per kilometre) of stream channel. Large though this estimate ap- 
pears, the observed losses can be accounted for readily by the evapotranspiration potential of the wide flood plains adjacent to the river, particularly near and upstream from Sericho. Moreover, recent drilling at Sericho has revealed saline ground-water bodies at the river and in areas several kilometres to the north and south of the river. These bodies are apparently continuous with saline ground water of the Mado Gashi area (C-3805, C-3814, C-3822, C-3830, pl. 5, table 8). Thus, seepage from the present channel or even from former channels to the south of the Ewaso Ng'iro is not a primary contributor to fresh-water recharge of the aquifer. Any recharge by underflow, if it occurs at all, would have to be confined to a narrow area, perhaps 10 to $12 \mathrm{~km}$ wide, to the west of Hadado. That is, the water-level and water-quality data suggest that the source of any underflow would be ground-water inflow from Isiolo and Marsabit Districts of the Eastern Province, northwest of Hadado. That area, almost entirely unexplored, apparently is underlain to some extent by the Merti Beds, or their equivalent. Access is difficult, as much of the area is covered by surficial volcanic debris and lava flows.

The possibility should not be discounted that the Merti aquifer receives recharge from rare heavy storms by percolation of rainfall in areas where permeable volcanic rocks directly overlie the Merti Beds,

The relatively small seasonal surface flow of the Ewaso Ng'iro in its main channel below Sericho and Habaswein is accompanied by widespread water-logging of its flood plains, former channels, oxbows, and other adjacent low-lying areas, such as the Lorian Swamp. This condition is caused by the widespread occurrence of hard gray or brownish-gray clays that were noted in many auger holes in the Lorian Swamp and also reported in boreholes C-3805 and C-3814 (table 13) near Sericho. In the Lorian Swamp area, the clays are found 0.5 to $1.0 \mathrm{~m}$ below land surface and are 3 or 4 $m$ thick. They are part of the Quaternary alluvial deposits that may have a thickness of 30 to 50 m near the Ewaso Ng'iro.

Most of the floodwater that covers the Lorian Swamp area intermittently is lost by evapotranspiration. A small amount may seep down to deeper clay zones where it may remain perched for a relatively short time. The deeper clays are apparently rather localized and occur at depths ranging from about 7 to $20 \mathrm{~m}$. They may sustain temporary bodies of perched water, tapped by dug wells, such as those at Sabena. These bodies generally last for several weeks or months following flooding or unusually heavy rains in the area. A perched water body at a depth of about $20 \mathrm{~m}$ 
was tapped in 1940 near an abandoned channel of the Ewaso Ng'iro, about $10 \mathrm{~km}$ southwest of Habaswein (SA 19, C-100, table 12). The water supply, however, began to fail soon after its discovery. Subsequent drilling in $\mathbf{1 9 5 5}$ failed to locate any water down to a depth of $61 \mathrm{~m}$ (C-2511). Drilling at the same site (C-3645) in 1970 again failed to locate shallow ground water, even though rainfall in 1968 had been at a record high. During the recent drilling operations (1969-72), indications of shallow ground water were found at only one site $(\mathrm{C}-3853)$, near the Ewaso Ng'iro, about $27 \mathrm{~km}$ upstream from Merti. The amount of water, however, was too small to be developed. At C-3821, near Sabule, the first water body found was perched above a clay layer between 82 and $95 \mathrm{~m}$. The borehole, however, was completed in the Merti aquifer at a depth of $148 \mathrm{~m}$, where water was found to be confined. At all other drill sites the Merti Beds and the overlying alluvium, where present, were unsaturated to about $90 \mathrm{~m}$ below ground level.

Although recharge to the Merti aquifer cannot be demonstrated, it seems that the volume of floodwater reaching the Lorian Swamp-Lak Dera area may be of such proportions at times as to effect recharge. Floodwater of the Ewaso Ng'iro itself would be a contributing factor, and there are other stream channels entering the Lorian Swamp-Lak Dera drainageway, particularly from the southwest, which may carry large amounts of water intermittently. Some of these are 50 to $70 \mathrm{~km}$ long and drain an area of about $7,500 \mathrm{~km}^{2}$ between Habaswein and Dadaab. These include the Galana Gof, Lak Telangor (Lagh Telangor), Lak Tuglub (Lagh Tugloob), and Lak Afwein (Lagh Afwein) (pl. 1). Their channels are well defined in the west, where relief is somewhat higher. Typically, the streambed deposits are medium to coarse sand, with some gravel, 2 to $10 \mathrm{~m}$ thick, resting on the rather impermeable clays of the Merti Beds. Much of the floodflow in these channels will penetrate the alluvial deposits, but some of it reaches the edge of the Lorian Swamp-Lak Dera lowlands. Some alluvial fans in these areas can be recognized on aerial photographs. It can be assumed that there are other fan or deltaic deposits, now covered by clays, where tributaries debouched in the past. Relatively clean sand, noted at some auger sites at and upstream from Meri between depths of 2 and $7 \mathrm{~m}$, may correspond to deltaic deposits. If these deposits are contiguous with present alluvial channel fill, they may constitute potential sites for recharge.

Intermittent flooding of parts of the area, resulting in recharge to the Merti aquifer, would cause local temporary mounds of fresh 
water and other irregularities on the potentiometric surface that may exist but are difficult to delineate on the basis of presently available data. A residual ground-water mound may be present in the *Kalalut area near borehole $\mathrm{C}-3685$, where heads are 7 to $8 \mathrm{~m}$ higher than at Habaswein, located $21 \mathrm{~km}$ up gradient. The groundwater mound near *Kalalut is suggested by the 100 -metre contour shown on plate 1 . Water-quality data also point to the intermittent, localized nature of recharge. Chloride concentrations do not increase down gradient, as would be expected in a homogenous flow system. The least mineralized ground water, containing 380 to $520 \mathrm{mg} / 1$ of dissolved solids, is found in isolated areas near Meri, north of Dadaab, and at *Darken, in the central and lower parts of the system (C-3687, C-3695, C-3240, table 8).

In an attempt to clarify the question of recharge to the Merti aquifer, water samples from 20 boreholes were collected for radiocarbon and tritium determinations in the laboratories of the U.S. Geological Survey. All samples contained less than 1 tritium unit. Thus not only do they contain no bomb tritium, but even prebomb tritium has decayed to below the analytical detection limit. They must, therefore, have been recharged at least 35 years ago. The radiocarbon analyses cannot be interpreted as absolute ages. Although some analytical work is still in progress, preliminary findings indicate that the water samples fall into four groups, each possibly representing in its alinement a discrete recharge event of major proportions. Preliminary data also suggest that these events may be hundreds to a few thousand years apart (Pearson and Swarzenski, 1974).

Ground-water withdrawals by boreholes in the area of the Merti aquifer were insignificant prior to 1957 and are still (1973) comparatively low. Estimated pumpage shown in table 7 indicates an increase from $28,900 \mathrm{~m}^{3}$ in 1970 to $69,500 \mathrm{~m}^{3}$ in 1973 .

As new boreholes are equipped with pumping plants in coming years, it will be necessary to monitor total withdrawals, water levels, and water quality of the Merti aquifer on a regular basis. Existing boreholes are generally from 110 to $140 \mathrm{~m}$ deep, and a very few reach $180 \mathrm{~m}$. Drilling thus far has been limited to the depth necessary to obtain amounts of water adequate for livestock or village use. Thus the ground-water reservoir is presently (1973) defined chiefly in two dimensions. There are indications that the Merti Beds below about $180 \mathrm{~m}$ are predominantly clay and presumably contain saline ground water, as suggested on plate 1 ,

\footnotetext{
51 tritium atom per $10^{18}$ hydrogen atoms, which is the limit of detection of most laboratories.
} 
TABLE 7.-Estimated ground-water withdrawals from the Merti aquifer, 1970 and 1973

\begin{tabular}{|c|c|c|c|}
\hline \multirow{2}{*}{ Location } & \multirow{2}{*}{$\begin{array}{c}\text { Borehole } \\
\text { No. }\end{array}$} & \multicolumn{2}{|c|}{$\begin{array}{c}\text { Estimated pumpage } \\
\text { (cubic metres per year) }\end{array}$} \\
\hline & & 1970 & 1973 \\
\hline "Darken _. & $\mathrm{C}-3240$ & 4,500 & 4,500 \\
\hline Dadaab & $\mathrm{C}-2485$ & 6,800 & 8,100 \\
\hline Liboi & C-2685 & 5,400 & 1,800 \\
\hline Do & C-3667 & & 10,000 \\
\hline Wel Merer & C-3085 & & 6,300 \\
\hline Alinjugul _-_- & C-2686 & 5,400 & \\
\hline Do & C-3831 & & 8,100 \\
\hline Habaswein -- & C-3218 & 6,800 & 200 \\
\hline Do & $\mathrm{C}-3654$ & ... & 9,100 \\
\hline Do & $\mathrm{C}-3655$ & $\begin{array}{ll}--- \\
--1\end{array}$ & 5,800 \\
\hline *Kalalut _. & C-3685 & -..- & 4,400 \\
\hline Meri & C-3727 & -..- & 4,400 \\
\hline Lorian Swamp & C-3751 & ---- & 2,700 \\
\hline Do & $\mathrm{C}-3752$ & $-\ldots$ & 1,400 \\
\hline Do & $\mathrm{C}-3697$ & $\cdots$ & 2,700 \\
\hline Total & $\ldots \ldots$ & 28,900 & 69,500 \\
\hline
\end{tabular}

$A-A^{\prime}$ and $B-B^{\prime}$. No boreholes in the Lorian Swamp area have reached very salty water, which is believed to occur at greater depths there than in adjacent areas. Ground water containing $10,000 \mathrm{mg} / \mathrm{l}$ or more of dissolved solids is found in adjacent areas, however, and it appears likely that very saline water also underlies the Lorian Swamp. Plate $1, B-B^{\prime}$, indicates very salty ground water at a depth of about $-50 \mathrm{~m}$ below sea level in the Lorian Swamp-*Kalalut area; this depth is based on data from three boreholes which are representative of the shallowest and deepest parts of the Merti aquifer thus far developed in the region. Moreover, some measure of control of the lines of equal dissolved solids, shown on plate $1, B-B^{\prime}$, is afforded by data from adjacent boreholes that reached saline water at Mado Gashi (C-3636) and near Lagh Bogal (C-3041).

Increasing development of the Merti aquifer may induce lateral and vertical movement of saline water. Exploration of the deeper part of the aquifer, to say 250 or $300 \mathrm{~m}$, would reveal where and to what extent a threat of salt-water encroachment from depth is present.

\section{QUATERNARY DEPOSITS}

Deposits of Pleistocene age are important in the Wajir and E1 Wak areas, where they are a source of permanent ground water at relatively shallow depth, accessible to dug wells. The Wajir Beds described by Joubert (1963) apparently can be correlated with the El Wak Beds in Mandera District (Baker and Saggerson, 
1958), in that both are characterized by limestone and gypsum beds, a combination indicative of evaporation, probably from intermittent shallow lakes that must have been fairly widespread in the region during the Pleistocene. There are other local occurrences of lacustrine limestones elsewhere in the province, which may also be of Pleistocene age. These limestones are, in general, not associated with water-bearing substrata. In the Banissa area, to the north of Derkali, about $20 \mathrm{~m}$ of claystones and conglomerates overlying the Jurassic limestones (pl. 1) may be of Pleistocene age, as suggested by Ayers (1952). The water-bearing properties of the Banissa Beds are unknown. Terrace deposits found along the major rivers and alluvial deposits underlying the Ewaso Ng'iro are also probably of Pleistocene age, whereas the alluvium in the other drainageways is largely of Holocene age. Because of low relief, similar lithology, and generally thick soil cover, the Quaternary deposits have not been distinguished from the older Merti Beds, and the unit shown on plate 1 is designated as undifferentiated deposits of Quaternary and Tertiary age.

The Wajir Beds form a discontinuous shallow-water aquifer within a radius of about $15 \mathrm{~km}$ from Wajir, particularly toward the northwest, west, and south. In this area, water can be obtained from wells dug to depths of 10 to $20 \mathrm{~m}$, wherever the clayey and silty sands underlying the limestones are sufficiently permeable. The succession of strata is highly variable and includes arenaceous limestone, 2 to $4 \mathrm{~m}$ thick, that is characterized by calcium carbonate concretions and solution cavities; calcareous silty and clayey sand; clay; marl; and gypsum. The total thickness is about 20 to $25 \mathrm{~m}$ in the Wajir area, where underlying clay, sand, and grit are believed to be part of the Merti Beds. In the Riba and Wajir Bor areas, to the northeast the Wajir Beds directly overlie limestone of Jurassic age.

There are about 300 shallow dug wells in the Wajir area that are used intermittently, and many others that have been abandoned in the past. The wells are commonly concentrated in groups of a dozen or more where water can be obtained readily. The shallow wells of the Wajir area have provided the only source of water for a large part of the district during droughts; thus the area is severely overgrazed. In seasons of adequate rainfall, a relatively small number of wells may be in use, while cattle are kept in distant pastures. During droughts, however, concentration of cattle occurs in Wajir, and the draft on water supplies is heavy; some wells are used constantly. Water is lifted by leather bucket to the surface, commonly from a depth of 3 to $10 \mathrm{~m}$. Water 
levels, yields, and water quality are highly variable, even within a single group of wells, as a result of local variations in the character of the water-bearing material. Most of the wells individually yield about 40 to $801 / \mathrm{min}$, but the best may yield $1501 / \mathrm{min}$ or more. In some cases, the yield obtained may be limited by the depth to which excavation below the water table is feasible.

Recharge to the shallow water table in the Wajir area apparently is largely by the infiltration of rain. It may be augmented in some degree by overland runoff from the north. The Merti Beds and older formations underlying the area north of Wajir are rather impermeable and contain water that is considerably more saline than the deeper ground water at Wajir. Bestow $(1953$, p. 30$)$ calculated recharge from rains at the rate of 14,800 $\mathrm{m}^{3} / \mathrm{km}^{2}$ (cubic metres per square kilometer) per year and considered that amount sufficient to sustain considerable southward underflow and also to sustain annual withdrawals of about 1 million $\mathrm{m}^{3}$ from the wells of the Wajir area. Total withdrawals from the wells are difficult to estimate, but may be as high as 4,500 $\mathrm{m}^{3} / \mathrm{d}$ during droughts.

A detailed description of the Wajir wells and their history is given by Bestow (1953). Unfortunately, individual wells that were measured or sampled in the course of his study could not be identified and related to present findings. Water levels fluctuate widely and rapidly with precipitation. Wells at Wag Halla (Wag Hala) were dry in 1952, and water was found only after deepening an existing well to $17 \mathrm{~m}$ (Bestow, 1953, p. 22). In recent years (1969-73), the water levels at Wag Halla have ranged from 11 to $15 \mathrm{~m}$ below land surface. Although water levels in Wag Halla rose about $3 \mathrm{~m}$ in response to the ample rains of 1971, water levels there and in three observation wells in the Wajir area were about $1 \mathrm{~m}$ lower in 1973 than they were in 1969.

Water from dug wells in the Wajir area is moderately mineralized, containing from 1,000 to $3,000 \mathrm{mg} / 1$ of dissolved solids. The water generally contains large amounts of calcium, magnesium, and sulfate, and is commonly very hard. Within the township of Wajir, a nitrate concentration of about $80 \mathrm{mg} / \mathrm{l}$ to more than $200 \mathrm{mg} / \mathrm{l}$ is excessive (table 9), and is probably indicative of pollution from surface sources.

In the area surrounding El Wak, gypsum and limestone occupy the center of a structural basin formed in rocks of Mesozoic age. El Wak Beds are considered to be of Pleistocene age (Baker and Saggerson 1958). They are about $25 \mathrm{~m}$ thick and overlie claystone and limestone of Cretaceous age that contain highly saline 
water (C-3850, tables 8, 11, and 13). El Wak Beds contain shallow ground water, apparently as a result of intermittent overland runoff into the center of the basin. Wells dug into the gypsiferous limestones at and near El Wak are the sole source of permanent water within a radius of about $50 \mathrm{~km}$ of the town. The wells are 18 to $24 \mathrm{~m}$ deep, and the water level was generally at 17 or $18 \mathrm{~m}$ below land surface during 1969-73. The wells yield individually about 40 to $80 \mathrm{l} / \mathrm{min}$ of rather unpalatable water, containing 2,500 to $4,000 \mathrm{mg} / \mathrm{l}$ of dissolved salts, largely calcium sulfate.

Alluvial deposits of Pleistocene (?) and Holocene age are intermittent and local sources of water supply in several localities in North Eastern Province. Following periods of ample rain and floodflow, water can be obtained from wells dug in the channel fill of many river courses at depths of 2 to $12 \mathrm{~m}$. These supplies commonly are limited to a few weeks or months. The Galana Gof, however, contains water in the deepest part of its alluvial channel fill that fails only after prolonged droughts. From the bedrock area between Garba Tula and Benane underflow persists along most of the Galana Gof, commonly as far as 15 or $20 \mathrm{~km}$ downstream from Mado Gashi (pl. 1). The intermittent nature of perched water in the Lorian Swamp area has been discussed previously. Although wells dug as deep as $20 \mathrm{~m}$ may yield a small amount of water following flooding or rains in the area, these supplies diminish and are exhausted rather rapidly. The sporadic distribution of clay that supports perched water, the regular distribution of water-bearing silt and sand, and the absence of an extensive perched-water level in the area of the Sabena wells were noted by Arnold (1952) in his investigation of ground water in the Lorian Swamp.

The flood-plain deposits adjacent to the Tana River, the Daua, and the Ewaso Ng'iro are generally fine textured, but probably in places contain zones where fresh-water supplies can be developed from shallow gravel-packed boreholes. Along the central reach of the Tana River, fresh ground water apparently is limited to the uppermost 8 to $12 \mathrm{~m}$ of alluvial silt and sand in the active flood plain. The underlying Merti Beds contain highly saline water that is not in hydraulic continuity with the river. Similarly, fresh water along the Daua is probably limited to the alluvial deposits of the present flood plain, as ground water in adjacent Jurassic rocks is known to be saline near Mandera. Near the Ewaso Ng'iro, saline ground water was found in Merti Beds near the river at Sericho and also to the north and south of the river. Holocene and Pleistocene deposits, extending to depth of about $53 \mathrm{~m}$ along the 
river in this vicinity, are largely impermeable, but contain sand and gravel at their base. Judicious exploration of the area may reveal permeable beds at shallower depth that are hydraulically continuous with river channel deposits. In an analogous situation, a very permeable fresh ground-water zone, close to the Ewaso Ng'iro, was found at a depth of $30 \mathrm{~m}$ at Merti in borehole C-3864.

\section{QUALITY OF GROUND WATER}

The fresh ground water in the Merti aquifer, containing less than $1,000 \mathrm{mg} / 1$ (milligrams per liter) of dissolved solids, is generally of the sodium bicarbonate type. This water is of good quality and is soft. Its $\mathrm{pH}$ is commonly between 7.2 and 7.8. Moreover, its concentration of fluoride and nitrate is, with very few exceptions, below the recommended limits for public supplies, of $0.8 \mathrm{mg} / \mathrm{l}$, fluoride and $45 \mathrm{mg} / \mathrm{l}$, nitrate (U.S. Public Health Service, 1962). To the northeast and southwest of the fresh-water zone shown on plate 5 , the ground water gradually becomes more mineralized with increased amounts of sodium, chloride, and bicarbonate and, to a lesser degree, sulfate. Characteristically, the moderately mineralized ground water of the Lorian Swamp-Lak Dera area and also the saline water of the area northwest of Habaswein, and at Sericho and Merti, contains less than $20 \mathrm{mg} / 1$ each of calcium and magnesium. It contains substantial amounts of bicarbonate, in all cases, and is either of the sodium bicarbonate chloride or of the sodium chloride bicarbonate type with $\mathrm{pH}$ values as high as 9.1 (pl. 5; table 8 ). Locally, concentrations of fluoride are excessive. For example, the salty ground water in the Merti-Sericho area contains from 12 to $37 \mathrm{mg} / \mathrm{l}$ fluoride (C-3805, C-3822, C-3853, table 8) which is possibly related to volcanism in the Merti area. The temperature of water from the principal aquifer ranges from $34.0^{\circ}$ to $39.2^{\circ} \mathrm{C}$, but it is commonly $36^{\circ}$ to $37^{\circ} \mathrm{C}$. The temperatures prevailing throughout the aquifer are rather higher than might be expected in view of the depths of the wells in which the temperatures were measured. They exceed average annual air temperatures by $8^{\circ}$ to $9^{\circ} \mathrm{C}$.

Ground water from boreholes tapping Precambrian crystalline rocks or consolidated sedimentary rocks of Mesozoic age commonly contains 2,000 to $4,000 \mathrm{mg} / 1$ of dissolved solids, which is marginally suitable for human consumption. There are, however, isolated areas where the dissolved-solids concentration is as much as $15,000 \mathrm{mg} / 1$. The ground water of the northern areas of the province is generally of sodium chloride type. The water also contains relatively large amounts of calcium and magnesium and is mod- 
erately hard to very hard. Locally, excessive nitrate concentrations, as high as $440 \mathrm{mg} / \mathrm{l}$, have been reported from widely separated areas, at *Asahaba, north of Fino, and from the area of Precambrian crystalline rocks north of Wajir (C-3569, C-3572, C-3899, C-3881, table 8). The high nitrate concentration of water from boreholes in these areas evidently is not due to surficial pollution. Rather, it is possible that the source lies in the buried soil zones, perhaps of late Tertiary or Pleistocene age, where nitrates may have been concentrated by ancient leguminous vegetation. Similarly, the high nitrate concentration ( 80 to $200 \mathrm{mg} / 1$ ) of shallow water in Wajir may also be related to paleosols. The Wajir wells, however, are contaminated to some extent by surface wastes. Nitrate concentrations in excess of $45 \mathrm{mg} / 1$ are considered to be harmful to infants (U.S. Public Health Service, 1962).

\section{GROUND-WATER AVAILABILITY}

Zones of fresh and saline ground water in the area of the Merti aquifer are delineated on plate 5 . Adjacent to the fresh-water zone (containing less than $1,000 \mathrm{mg} / \mathrm{l}$ of dissolved solids), are large unexplored areas, particularly toward the northeast, where mineralization apparently increases gradually and where ground water in sufficient quantity and of suitable chemical quality for livestock use could be obtained from boreholes.

Prospects for additional ground-water development seem favorable from the Cretaceous rocks of eastern Mandera District (pl. 5). Also, the large area underlain by Jurassic rocks is largely unexplored. Drilling in the past has been limited to areas where the Jurassic rocks are predominantly shales. Future drilling may disclose limestone beds in the Jurassic sequence where permeability is enhanced by solution cavities, or it may reveal permeable zones between weathered basement rock and overlying Triassic or Jurassic strata that may yield adequate amounts of water to boreholes. The Precambrian metamorphic and igneous rocks of the basement complex, even where fracture zones are encountered, generally yield very small quantities of water. Modest yields, of 25 to $100 \mathrm{l} / \mathrm{min}$, have been obtained only from boreholes that tap water in extensive weathered zones.

The area extending southeast from Garissa to the Indian Ocean appears to be underlain predominantly by saline ground water, as deduced from a few boreholes drilled in the course of oil exploration. There may be small local bodies of fresh ground water, fed by surface runoff, in lenticular zones overlying saline water. Fresh water was reported in a borehole C-3120 (pl. 5; table 8) south- 
east of Bata. Water obtained at Bata in borehole C-3070 (pl. 5; table 8), although containing $9,515 \mathrm{mg} / 1$ of dissolved salts, is substantially less mineralized than water to the north and south and may be indicative of a zone of diffusion between relatively fresh and saline ground water in that area. If other fresh-water lenses, albeit of small local extent, are present, they could augment water supplies in an area that presently depends exclusively on surface-water storage. Electrical resistivity surveys may be useful tools in the exploration for shallow ground-water lenses in the southern part of Garissa District.

\section{FUTURE GROUND-WATER DEVELOPMENT}

Fresh ground water contained in the Merti aquifer is probably the major economic asset of the North Eastern Province. Because of the general inaccessibility of the area and because of shortcomings in logistic support in the past, it was not possible to explore this resource as fully as might have been desirable. The increasing need to develop the aquifer in the future will bring a corresponding need for systematic and continuous monitoring of changes in ground-water levels and water quality. The extent of the Merti aquifer is practically known in only two dimensions, and it will be necessary to explore the deeper parts of the aquifer, to 250 cr $300 \mathrm{~m}$, in order to ascertain whether and to what extent the danger of salt-water intrusion is present in the Lorian SwampLak Dera area. Also research will be needed to determine the mechanism by which recharge to the aquifer, through $90 \mathrm{~m}$ or more of unsaturated sediments, can be effected under the given climatic conditions. Possibly a series of piezometers, installed at different depths in areas where recharge is likely to occur, would yield relevant data. Moreover, the hydraulic properties of the aquifer are not well known, and additional data can be obtained from properly controlled aquifer tests, after the installation of electric pumps in some of the boreholes that have potentially high yields. It may also be advisable to perform aquifer tests on boreholes of experimental design, having 204-mm or larger casing and fully penetrating screens.

Ground-water exploration to shallow depth $(50$ to $70 \mathrm{~m})$ could be undertaken by the Water Department in such areas as southern Garissa District or along the course of the Ewaso Ng'iro. Available auger-type drills have proved inadequate in the past to penetrate concretionary zones that are common almost everywhere. A small truck-mounted hydraulic rotary drilling rig would be able to overcome these difficulties and would permit rapid ex- 
ploration of areas where a large number of test holes might be required.

\section{SELECTED REFERENCES}

Arnold, R. T., 1952, Lorian Swamp Ground Water Investigation, 1952: Public Works Department, Nairobi, Kenya, unpub. report.

Ayers, F. M., 1952, Geology of the Wajir-Mandera District, North-east Kenya: Geol. Survey Kenya, Rept. 22, 31 p.

Baker, B. H., and Saggerson, E. P., 1958, Geology of the El Wak-Aus Manduli Area: Geol. Survey Kenya, Rept. 44, 48 p.

Bestow, T. T., 1953, Report on the geology and hydrology of Wajir District: Public Works Department, Nairobi, Kenya, unpub. report.

Bestow, T. T., and others, 1963, An investigation into the water resources of the Ewaso Ng'iro Basin, Kenya: Ministry of Works, Hydraulic Branch, Rept. No. 5, 50 p.

Chambers, R. H. J., 1969, Report on social and administrative aspects of range management development in the Northeastern Province, Kenya: Ministry of Agriculture, Range Management Division, unpub. report.

Classen, G. A., 1951, Engineer Geologist's report on the surface and shallow water supplies in the Districts of Moyale, Wajir, Garissa and Isiolo, Northern Frontier Province (Kenya): Office for African Land Utilization and Settlement, unpub. report.

Dixey, F., 1944, Hydrographical Survey of the Northern Frontier District, Kenya: Public Works Department, Nairobi, Kenya, unpub. report.

Edwards, D. C., 1943, Report on the grazing areas of the Northern Frontier District of Kenya: Department of Agriculture, unpub. report, $32 \mathrm{p}$.

Haywood, C. H., 1913, The Lorian Swamp: Geogr. Journal, 41, p. 463-468.

Humphries and Sons, Howard, 1958, The Northern Frontier Province and Samburu District Water Development Scheme, 1950-1958: A report of the Government of Kenya (Ministry of Agriculture) by the Consulting Engineer.

Joubert, P., 1960, Geology of the Mandera-Damassa Area: Geol. Survey Kenya, Rept. 48, 65 p.

- 1963, Geology of the Wajir-Wajir Bor Area: Geol. Survey Kenya, Rept. 57, $34 \mathrm{p}$.

Matheson, F. J., 1971, Geology of the Garba Tula Area: Geol. Survey Kenya, Rept. 88, $30 \mathrm{p}$.

Mundorff, M. J., and Swarzenski, W. V., 1969, Report on drilling in the North Eastern Province by the 521st Specialist Team, R. E., Phase II, Mandera District: Water Devel. Div., Kenya Ministry of Agriculture and USAID, unpub. report , 9 p., 3 figs., 2 tables.

Mundorff, M. J., Swarzenski, W. V., Kornegay, R. C., and Mass, F. H., 1970, Development plan and feasibility study of a Pilot Range Development Project North Eastern Province, Kenya: Kenya Ministry of Agriculture and USAID, unpub. report.

Pearson, F. J., Jr., and Swarzenski, W. V., 1974, Carbon-14 evidence for the origin of arid region ground water: Internat. Atomic Energy Agency, Vienna, Paper IAEA/SM-182-22, 14 p. 
Saggerson, E. P., and Miller, J. M., 1957, Geology of the Takabba-Wergedud Area, Mandera District: Geol. Survey Kenya, Rept. 40, 42 p.

Selby, J., 1969, 521st Specialist Team, R. E. Well Drilling, Phase I-Wajir District, Hydrogeological Rept: Water Dev. Div., Ministry of Agriculture, unpub. report.

Swarzenski, W. V., Kornegay, R. C., and Mass, F. H., 1971, Supplementary report to Development plan and feasibility study on a Pilot Range Development Project, North Eastern Province, Kenya: Kenya Ministry of Agriculture and USAID, unpub. report.

Thompson, A. O., and Dodson, R. G., 1958, Geology of the Derkali-Melka Murri Area: Geol. Survey Kenya, Rept. 43, 35 p.

1960, Geology of the Bur Mayo-Turbaj area: Geol. Survey Kenya, Rept. 47, 49 p.

U.S. Public Health Service, 1961, Drinking water standards: Public Health Service Pub. 956, 61 p.

Walsh, J., 1972, Geology of the Moyale area: Geol. Survey Kenya, Rept. 89, $33 \mathrm{p}$.

Watson, R. M., 1969, North Eastern Province livestock census: Ministry of Agriculture, Range Management Div., unpub. rept.

Wickenburg, Eduard, Count, 1903, Von Dschibuti bis Lamu: Petermann's Mitteilungen, v. 49, p. 193-199.

Williams, S. A. J., and Matheson, F. J. (Publication pending) Geological map of the Buna area: Geol. Survey Kenya; to accompany Rept. 95, in preparation. 

TABLES 8-13 


\section{N48 HYDROLOGY OF AFRICA AND THE MEDITERRANEAN REGION}

TABLE 8.-Chemical analyses of waters [Results in milligrams per litre except as indicated. T, trace; Pres, present; <0.1, less than 0.1 ;

Borehole: Serial numbers are assigned by the Kenya Water Department to all boreholes in Kenya. The prefix, C--, should be added to all serial numbers listed in this table.

Date of collection: Month, day, and year of collection of sample.

Depth: In metres below land surface.

Temperature: Temperature of water, in degrees Celsius.

Specific conductance: In micromhos at $25^{\circ} \mathrm{C}$.

\begin{tabular}{|c|c|c|c|c|c|c|c|c|c|c|c|}
\hline $\begin{array}{l}\text { Bore- } \\
\text { hole }\end{array}$ & $\begin{array}{l}\text { Date } \\
\text { of } \\
\text { collec- } \\
\text { tion }\end{array}$ & Depth & $\begin{array}{l}\text { Tem- } \\
\text { pera- } \\
\text { ture }\end{array}$ & pH & $\begin{array}{l}\text { Spe- } \\
\text { cific } \\
\text { con- } \\
\text { duct- } \\
\text { ance }\end{array}$ & $\begin{array}{l}\text { Dis- } \\
\text { solved } \\
\text { solids }\end{array}$ & $\begin{array}{l}\text { Silica } \\
\left(\mathrm{SiO}_{2}\right)\end{array}$ & $\begin{array}{l}\text { Iron } \\
(\mathrm{Fe})\end{array}$ & $\begin{array}{c}\text { Man- } \\
\text { ga- } \\
\text { nese } \\
(\mathbf{M n})\end{array}$ & $\begin{array}{l}\text { Cal- } \\
\text { cium } \\
\text { (Ca) }\end{array}$ & $\begin{array}{c}\text { Mag- } \\
\text { ne- } \\
\text { sium } \\
(\mathrm{Mg})\end{array}$ \\
\hline \multicolumn{12}{|c|}{ Mandera District } \\
\hline $\begin{array}{l}2570 \\
2570 \\
2571 \\
2616 \\
3297 \\
3569 \\
3571 \\
3572 \\
3696 \\
3850 \\
3851 \\
3861 \\
3865 \\
\end{array}$ & $\begin{array}{r}9-6-56 \\
9-26-61 \\
11-13-56 \\
12-28-56 \\
6-24-64 \\
3--69 \\
4-\quad-69 \\
4-\quad-69 \\
10-10-70 \\
8-5-72 \\
9-19-72 \\
9-15-72 \\
11-21-72 \\
\end{array}$ & $\begin{array}{r}41.5 \\
41.5 \\
41.8 \\
91.5 \\
45.7 \\
84.5 \\
125.0 \\
125.0 \\
122.0 \\
133.6 \\
76.2 \\
88.7 \\
244.0 \\
\end{array}$ & $\begin{array}{l}-- \\
--- \\
--- \\
--- \\
--- \\
--- \\
--- \\
--- \\
--- \\
30.0 \\
30.5 \\
--- \\
\end{array}$ & $\begin{array}{l}8.7 \\
7.3 \\
6.9 \\
7 .- \\
7.3 \\
7.7 \\
7.9 \\
7.7 \\
7.7 \\
7.7 \\
7.6 \\
7.7 \\
7.7 \\
\end{array}$ & $\begin{array}{r}\overline{5,300} \\
-\cdots- \\
7,500 \\
4,500 \\
5,100 \\
4,900 \\
4,100 \\
13,800 \\
3,800 \\
4,250 \\
3,200 \\
\end{array}$ & $\begin{array}{r}3,280 \\
4,080 \\
2,730 \\
4,070 \\
4,870 \\
2,810 \\
2,990 \\
2,830 \\
2,870 \\
11,900 \\
2,840 \\
2,980 \\
2,550 \\
\end{array}$ & $\begin{array}{r}13 \\
25 \\
24 \\
36 \\
25 \\
90 \\
10 \\
30 \\
100 \\
20 \\
60 \\
60 \\
30 \\
\end{array}$ & $\begin{array}{l}0.20 \\
.10 \\
.40 \\
T \\
0 \\
>.1 \\
>.1 \\
>.1 \\
0.20 \\
.20 \\
.20 \\
.30 \\
.10 \\
\end{array}$ & $\begin{array}{l}--- \\
--- \\
--- \\
--- \\
--- \\
--- \\
--- \\
-\cdots \\
--- \\
--- \\
0.10 \\
\end{array}$ & $\begin{array}{r}184 \\
186 \\
174 \\
314 \\
189 \\
170 \\
213 \\
98 \\
194 \\
628 \\
192 \\
211 \\
120 \\
\end{array}$ & $\begin{array}{r}4 \\
-152 \\
255 \\
188 \\
145 \\
209 \\
164 \\
136 \\
475 \\
122 \\
144 \\
64 \\
\end{array}$ \\
\hline \multicolumn{12}{|c|}{ Wajir District } \\
\hline $\begin{array}{l}2643 \\
3041 \\
3110 \\
3155 \\
3218 \\
3218 \\
3306 \\
3306 \\
3306 \\
3527 \\
3541 \\
3549 \\
3654 \\
3655 \\
3656 \\
3657 \\
3658 \\
3685 \\
3686 \\
3687 \\
3715 \\
3726 \\
3727 \\
3769 \\
3788 \\
3792 \\
3811 \\
3820 \\
3821 \\
3828 \\
3880 \\
3881 \\
3891 \\
3893 \\
3899 \\
3914 \\
3915 \\
3917 \\
3918 \\
3931 \\
\end{array}$ & $\begin{array}{r}2-4-57 \\
7-1-60 \\
2-14-61 \\
8-30-63 \\
3-13-63 \\
9-7-71 \\
8-12-64 \\
8-12-64 \\
9-18-64 \\
12-18-68 \\
5-22-72 \\
4-20-70 \\
8-25-71 \\
5-23-70 \\
1-31-70 \\
1-4-70 \\
3-19-70 \\
8-6-70 \\
8-6-70 \\
8-26-70 \\
2-20-71 \\
7-11-72 \\
5-26-71 \\
8-25-71 \\
2-9-72 \\
3-19-72 \\
4-1-72 \\
5-28-72 \\
6-6-72 \\
6-26-72 \\
2-19-73 \\
3-17-73 \\
2-24-73 \\
5-10-73 \\
5-8-73 \\
5-23-73 \\
6-10-73 \\
6-22-73 \\
6-12-73 \\
8-21-73 \\
\end{array}$ & $\begin{array}{r}122.0 \\
175.4 \\
140.3 \\
186.4 \\
143.9 \\
143.9 \\
119.0 \\
145.5 \\
263.0 \\
32.0 \\
45.7 \\
45.7 \\
134.2 \\
120.2 \\
20.4 \\
61.0 \\
61.0 \\
108.3 \\
183.0 \\
121.7 \\
136.9 \\
140.0 \\
144.3 \\
132.1 \\
119.5 \\
112.8 \\
128.7 \\
128.7 \\
147.9 \\
224.2 \\
76.2 \\
94.8 \\
32.9 \\
205.1 \\
84.0 \\
149.3 \\
117.0 \\
205.3 \\
158.0 \\
152.0 \\
\end{array}$ & 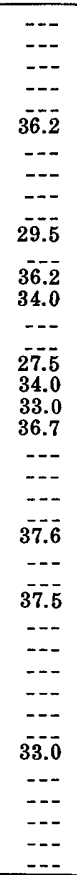 & $\begin{array}{l}7.8 \\
8.1 \\
7.1 \\
9.1 \\
7.5 \\
7.9 \\
7.5 \\
7.5 \\
7.9 \\
7.3 \\
8.3 \\
7.8 \\
8.4 \\
7.7 \\
7.8 \\
7.7 \\
7.8 \\
7.8 \\
7.8 \\
8.0 \\
7.7 \\
9.0 \\
7.7 \\
7.5 \\
8.3 \\
7.7 \\
7.5 \\
7.4 \\
7.3 \\
7.7 \\
7.3 \\
7.5 \\
8.4 \\
8.2 \\
7.7 \\
6.9 \\
7.8 \\
7.8 \\
8.4 \\
7.3\end{array}$ & \begin{tabular}{r}
---- \\
1,150 \\
2,600 \\
1,100 \\
1,080 \\
2,400 \\
2,400 \\
$-\cdot-$ \\
\hdashline 1,360 \\
1,200 \\
1,080 \\
1,000 \\
650 \\
1,200 \\
1,000 \\
1,200 \\
2,600 \\
700 \\
700 \\
2,050 \\
750 \\
4,500 \\
710 \\
1,220 \\
15,500 \\
820 \\
1,550 \\
12,600 \\
20,600 \\
4,400 \\
1,240 \\
2,550 \\
6,200 \\
5,500 \\
6,500 \\
9,500 \\
9,100 \\
4,200
\end{tabular} & $\begin{array}{r}15,100 \\
11.400 \\
730 \\
1,450 \\
765 \\
720 \\
1,480 \\
1,540 \\
3,750 \\
4,250 \\
720 \\
1,460 \\
740 \\
795 \\
472 \\
870 \\
764 \\
920 \\
1,700 \\
420 \\
480 \\
1,290 \\
545 \\
2,750 \\
460 \\
740 \\
11,000 \\
535 \\
830 \\
10,800 \\
15,800 \\
2,960 \\
824 \\
1,500 \\
3,660 \\
3,190 \\
\mathbf{5 , 0 0 0} \\
8,800 \\
6,190 \\
2,650\end{array}$ & $\begin{array}{r}9 \\
25 \\
45 \\
1 \\
35 \\
50 \\
10 \\
10 \\
- \\
8 \\
60 \\
60 \\
50 \\
35 \\
110 \\
40 \\
35 \\
60 \\
20 \\
25 \\
40 \\
5 \\
20 \\
30 \\
40 \\
50 \\
15 \\
30 \\
35 \\
10 \\
50 \\
60 \\
50 \\
30 \\
80 \\
10 \\
70 \\
20 \\
50 \\
20\end{array}$ & $\begin{array}{l}0.70 \\
T \\
<.1 \\
0 .- \\
.20 \\
0 \\
0 \\
0 \\
T \\
0 \\
.40 \\
.40 \\
.40 \\
>.1 \\
0 \\
0 \\
>.01 \\
0 \\
.15 \\
.20 \\
.40 \\
.40 \\
0 \\
.10 \\
0 \\
.10 \\
0 \\
0 \\
.20 \\
0 \\
-50 \\
.10 \\
.10 \\
.30 \\
.10 \\
0 \\
0 \\
.5 \\
.20 \\
\end{array}$ & 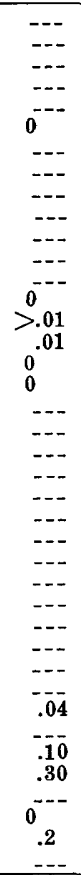 & $\begin{array}{r}495 \\
428 \\
70 \\
9 \\
27 \\
27 \\
82 \\
90 \\
309 \\
135 \\
36 \\
29 \\
25 \\
31 \\
15 \\
61 \\
31 \\
19 \\
264 \\
22 \\
39 \\
2 \\
17 \\
12 \\
30 \\
40 \\
200 \\
30 \\
105 \\
560 \\
1,780 \\
260 \\
48 \\
7 \\
208 \\
110 \\
56 \\
285 \\
144 \\
326 \\
\end{array}$ & $\begin{array}{r}501 \\
-47 \\
--- \\
18 \\
58 \\
67 \\
118 \\
--- \\
38 \\
93 \\
39 \\
17 \\
57 \\
42 \\
34 \\
25 \\
85 \\
7 \\
25 \\
0 \\
11 \\
31 \\
25 \\
43 \\
390 \\
14 \\
51 \\
324 \\
1,330 \\
300 \\
53 \\
6 \\
50 \\
10 \\
65 \\
410 \\
168 \\
81 \\
\end{array}$ \\
\hline \multicolumn{12}{|c|}{ Garissa District } \\
\hline $\begin{array}{l}2485 \\
2685 \\
2686 \\
2687 \\
2718 \\
2719 \\
3033 \\
3038 \\
3070 \\
3085 \\
3120\end{array}$ & $\begin{array}{r}8-6-55 \\
6-18-57 \\
6-18-57 \\
7-1-57 \\
8-24-57 \\
2-14-61 \\
7-26-60 \\
7-26-60 \\
10-12-60 \\
12-12-60 \\
3-13-61\end{array}$ & $\begin{array}{r}128.4 \\
93.9 \\
109.2 \\
54.9 \\
78.1 \\
79.3 \\
134.2 \\
101.5 \\
97.6 \\
128.1 \\
70.4\end{array}$ & $\begin{array}{l}--- \\
--- \\
--- \\
---\end{array}$ & $\begin{array}{l}8.1 \\
7.1 \\
8.1 \\
8.1 \\
7.5 \\
6.9 \\
7.9 \\
7.3 \\
7.3 \\
7.5 \\
7.1\end{array}$ & $\begin{array}{r}-\cdots \\
-\cdots, 00 \\
33,000 \\
-13,300 \\
1,550 \\
1,430\end{array}$ & $\begin{array}{r}720 \\
710 \\
805 \\
22,100 \\
35,400 \\
25,900 \\
6,910 \\
12,800 \\
9,520 \\
1,040 \\
1,200\end{array}$ & $\begin{array}{r}4 \\
26 \\
13 \\
10 \\
12 \\
30 \\
25 \\
40 \\
25 \\
25 \\
35\end{array}$ & $\begin{array}{l}0.3 \\
1.5 \\
1.5 \\
.8 \\
.7 \\
0 \\
0 \\
.2 \\
0.3 \\
0\end{array}$ & $\begin{array}{l}--- \\
--- \\
--- \\
--- \\
--- \\
--- \\
--- \\
--- \\
--- \\
---\end{array}$ & $\begin{array}{r}-\overline{71} \\
--- \\
\overline{3} \overline{15} \\
392 \\
22 \\
126 \\
214 \\
\overline{15} \overline{7}\end{array}$ & \begin{tabular}{c}
$-\overline{45}$ \\
--- \\
$\overline{437}$ \\
$-\cdots-$ \\
\hdashline$\overline{16 \overline{4}}$ \\
$\overline{62}$
\end{tabular} \\
\hline
\end{tabular}


from boreholes, northeastern Kenya

$>0.1$; more than 0.1 Analyses by Kenya Government Chemist's Department, Nairobi, except indicated]

Dissolved solids: Residue on evaporation at $180^{\circ} \mathrm{C}$

Aquifer: A, alluvial deposits of Quaternary age; $P$, semi-consolidated deposits (Merti Beds) of Pliocene age: $M$, consolidated sedimentary rocks of Mesozoic age; $C$, crystalline rocks of Precambrian age.

Remarks: S, analysis by British Petroleum-Shell Co., Ltd.

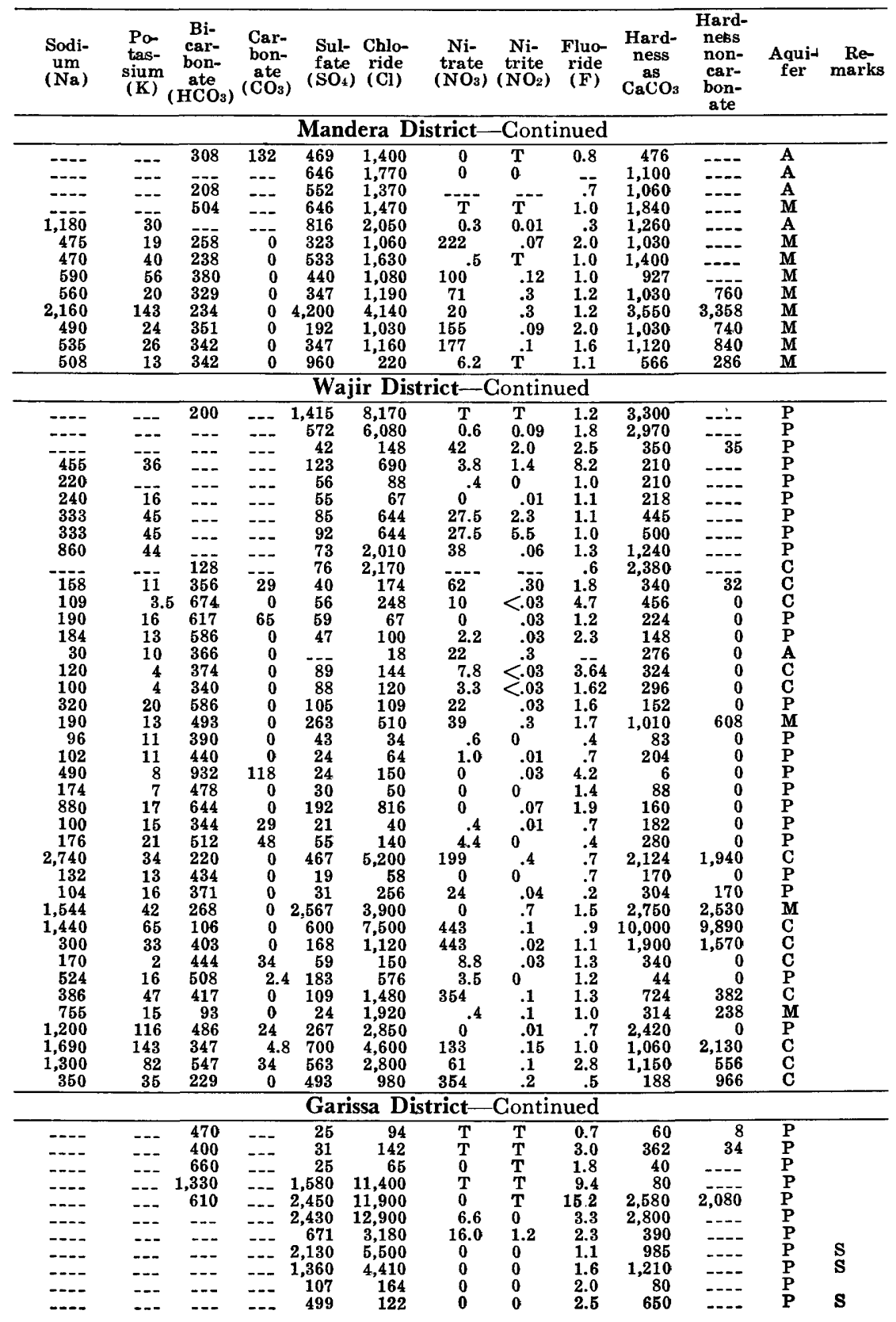


TABLE 8.-Chemical analyses of waters from

\begin{tabular}{|c|c|c|c|c|c|c|c|c|c|c|c|}
\hline $\begin{array}{c}\text { Bore- } \\
\text { hole }\end{array}$ & $\begin{array}{l}\text { Date } \\
\text { of } \\
\text { collec- } \\
\text { tion }\end{array}$ & Depth & $\begin{array}{l}\text { Tem- } \\
\text { pera- } \\
\text { ture }\end{array}$ & $\mathbf{p H}$ & $\begin{array}{l}\text { Spe- } \\
\text { cific } \\
\text { con- } \\
\text { duct- } \\
\text { ance }\end{array}$ & $\begin{array}{l}\text { Dis- } \\
\text { solved } \\
\text { solids }\end{array}$ & $\begin{array}{l}\text { Silica } \\
\left(\mathrm{SiO}_{2}\right)\end{array}$ & $\begin{array}{l}\text { Iron } \\
(\mathrm{Fe})\end{array}$ & $\begin{array}{c}\text { Man- } \\
\text { ga- } \\
\text { nese } \\
(\mathrm{Mn})\end{array}$ & $\underset{(\mathrm{Ca})}{\text { Cal- }}$ & $\begin{array}{c}\text { Mag- } \\
\text { ne- } \\
\text { sium } \\
(\mathrm{Mg})\end{array}$ \\
\hline \multicolumn{12}{|c|}{ Garissa District-Continued } \\
\hline $\begin{array}{l}3224 \\
3240 \\
3411 \\
3591 \\
3635 \\
3667 \\
3684 \\
3695 \\
3697 \\
3751 \\
3752 \\
3753 \\
\mathbf{3 7 7 0} \\
3781 \\
3804 \\
3831 \\
3852 \\
3860 \\
3877 \\
\mathbf{3 9 0 2} \\
\end{array}$ & $\begin{array}{r}8-28-62 \\
6-24-63 \\
6-29-66 \\
1-30-68 \\
9-30-69 \\
5-28-70 \\
7-5-70 \\
10-1-70 \\
11-21-70 \\
7-20-71 \\
3-7-71 \\
10-2-71 \\
10-13-71 \\
1-29-72 \\
4-11-72 \\
7-29-72 \\
9-14-72 \\
11-11-72 \\
2-24-73 \\
4-5-73 \\
\end{array}$ & $\begin{array}{r}123.5 \\
139.7 \\
139.4 \\
231.8 \\
7.0 \\
99.7 \\
119.2 \\
130.8 \\
122.9 \\
133.6 \\
151.6 \\
113.7 \\
165.3 \\
122.9 \\
158.6 \\
134.8 \\
146.7 \\
134.8 \\
128.1 \\
101.1\end{array}$ & 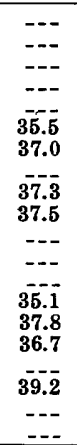 & $\begin{array}{l}\mathbf{7 . 5} \\
8.5 \\
7.1 \\
8.5 \\
7.7 \\
7.4 \\
7.5 \\
7.8 \\
8.1 \\
7.7 \\
7.8 \\
7.9 \\
8.7 \\
7.7 \\
7.8 \\
8.0 \\
8.6 \\
7.5 \\
7.6 \\
7.3\end{array}$ & $\begin{array}{r}\mathbf{1 5 , 5 0 0} \\
\mathbf{5 4 0} \\
-\times-. \\
-\mathbf{6 5 0} \\
950 \\
1,800 \\
\mathbf{7 1 0} \\
\mathbf{1 , 8 0 0} \\
1,760 \\
\mathbf{1 , 7 5 0} \\
1,530 \\
11,800 \\
1,550 \\
10,200 \\
1,200 \\
930 \\
750 \\
850 \\
1,040\end{array}$ & $\begin{array}{r}\mathbf{1 5 , 5 4 0} \\
\mathbf{3 8 0} \\
\mathbf{1 3 , 4 0 0} \\
\mathbf{5 , 7 8 0} \\
\mathbf{4 6 6} \\
\mathbf{7 1 6} \\
\mathbf{1 , 1 8 0} \\
\mathbf{5 2 0} \\
\mathbf{1 , 2 0 0} \\
\mathbf{1 , 0 8 0} \\
\mathbf{1 , 1 9 0} \\
\mathbf{1 , 0 1 0} \\
\mathbf{8 , 3 7 0} \\
\mathbf{1 , 1 3 0} \\
\mathbf{7 , 6 0 0} \\
\mathbf{7 2 5} \\
\mathbf{7 0 0} \\
\mathbf{5 2 5} \\
\mathbf{5 0 5} \\
\mathbf{6 7 5}\end{array}$ & $\begin{array}{l}25 \\
25 \\
35 \\
-- \\
90 \\
60 \\
35 \\
60 \\
25 \\
20 \\
20 \\
30 \\
4 \\
30 \\
25 \\
25 \\
20 \\
35 \\
35 \\
70\end{array}$ & $\begin{array}{l}0 \\
0 \\
0 \\
-.2 \\
.0 \\
0 \\
0 \\
.05 \\
.3 \\
.04 \\
.8 \\
.8 \\
.2 \\
.6 \\
.2 \\
.1 \\
.1 \\
.5 \\
.1 \\
\end{array}$ & $\begin{array}{l}--- \\
--- \\
--- \\
--- \\
-05 \\
--- \\
--- \\
--- \\
--- \\
--- \\
--- \\
--- \\
--- \\
--- \\
--- \\
0 \\
0\end{array}$ & $\begin{array}{c}852 \\
16 \\
560 \\
-56 \\
56 \\
70.5 \\
34 \\
10 \\
20 \\
4 \\
19 \\
10 \\
12 \\
17 \\
8 \\
9 \\
30 \\
32 \\
85 \\
\end{array}$ & $\begin{array}{l}635 \\
10 \\
170 \\
-7 \overline{14} \\
46 \\
62.5 \\
29 \\
46 \\
17 \\
6 \\
8 \\
13 \\
9 \\
19 \\
7.7 \\
6.5 \\
16 \\
21 \\
40 \\
\end{array}$ \\
\hline \multicolumn{12}{|c|}{ Isiolo District } \\
\hline $\begin{array}{r}100 \\
\mathbf{3 6 3 6} \\
\mathbf{3 8 0 5} \\
\mathbf{3 8 1 4} \\
\mathbf{3 8 2 2} \\
\mathbf{3 8 3 0} \\
\mathbf{3 8 5 3} \\
\mathbf{3 8 6 4}\end{array}$ & $\begin{array}{r}9-7-40 \\
11-24-69 \\
2-22-72 \\
3-23-72 \\
7-24-72 \\
9-11-72 \\
11-9-72 \\
10-13-72\end{array}$ & $\begin{array}{r}22.3 \\
188.2 \\
91.5 \\
51.8 \\
125.0 \\
129.0 \\
67.1 \\
30.8\end{array}$ & $\begin{array}{l}-- \\
--- \\
--- \\
--- \\
--- \\
--- \\
--\end{array}$ & $\begin{array}{l}7.5 \\
8.7 \\
9.1 \\
8.6 \\
8.5 \\
8.4 \\
8.6 \\
7.9\end{array}$ & $\begin{array}{r}17,000 \\
8,100 \\
14,000 \\
10,400 \\
10,000 \\
26,400 \\
870\end{array}$ & $\begin{array}{r}1,410 \\
10,600 \\
5,660 \\
10,000 \\
7,970 \\
8,080 \\
20,300 \\
470\end{array}$ & $\begin{array}{l}20 \\
2.0 \\
20 \\
15 \\
25 \\
30 \\
30\end{array}$ & $\begin{array}{l}0.10 \\
.2 \\
.80 \\
.30 \\
.6 \\
.30\end{array}$ & $\begin{array}{l}--- \\
-- \\
--- \\
--- \\
--- \\
---\end{array}$ & $\begin{array}{c}-50 \\
2.5 \\
16 \\
3 \\
8 \\
14.5 \\
41\end{array}$ & $\begin{array}{c}-5 \\
1.0 \\
0 \\
1 \\
3 \\
4 \\
32\end{array}$ \\
\hline
\end{tabular}

TABLE 9.-Chemical analyses of waters from [Results in milligrams per litre, except as indicated. Analyses Location: Name of town or village in or near which corresponding well is located. Well: Serial numbers assigned by Kenya Water Department in 1969.

Date of collection: Month, day, and year of collection of samples.

\begin{tabular}{|c|c|c|c|c|c|c|c|c|c|c|}
\hline Location & Well & $\begin{array}{l}\text { Date } \\
\text { of } \\
\text { collec- } \\
\text { tion }\end{array}$ & Depth & $\mathbf{p H}$ & $\begin{array}{l}\text { Spe- } \\
\text { cific } \\
\text { con- } \\
\text { duct- } \\
\text { ance }\end{array}$ & $\begin{array}{l}\text { Dis- } \\
\text { solved } \\
\text { solids }\end{array}$ & $\begin{array}{r}\text { Silica } \\
\left(\mathrm{SiO}_{2}\right)\end{array}$ & $\begin{array}{l}\text { Iron } \\
(\mathrm{Fe})\end{array}$ & $\underset{\text { ganese }}{\text { Man- }}$ & $\begin{array}{l}\text { Cal- } \\
\text { cium }\end{array}$ \\
\hline \multicolumn{11}{|c|}{ Wajir Township } \\
\hline $\begin{array}{l}\text { Primary School --- } \\
\text { Primary School } \\
\text { Primary School } \\
\text { Primary School } \\
\text { Secondary School -- } \\
\text { Kenya Army } \\
\text { Kenya Army } \\
\text { Game Department- } \\
\text { Consolata Mission - } \\
\text { Consolata Mission - } \\
\text { Livestock Market- } \\
\text { ing Division. }\end{array}$ & $\begin{array}{r}17 \\
34 \\
35 \\
35 \\
29 \\
6 \\
13 \\
38 \\
39 \\
8 \\
41\end{array}$ & $\begin{array}{l}7-12-73 \\
7-11-73 \\
7-8-72 \\
7-11-73 \\
7-8-73 \\
7-11-73 \\
7-11-73 \\
7-7-73 \\
7-7-73 \\
7-13-73 \\
7-13-73\end{array}$ & $\begin{array}{r}10 \\
8 \\
9 \\
9 \\
8 \\
15 \\
13 \\
8 \\
7 \\
11 \\
6\end{array}$ & $\begin{array}{l}\mathbf{7 . 6} \\
\mathbf{7 . 8} \\
\mathbf{7 . 5} \\
\mathbf{7 . 6} \\
\mathbf{7 . 4} \\
\mathbf{7 . 3} \\
\mathbf{7 . 7} \\
\mathbf{7 . 2} \\
\mathbf{7 . 5} \\
\mathbf{7 . 6} \\
\mathbf{7 . 5}\end{array}$ & $\begin{array}{l}2,500 \\
1,780 \\
2,050 \\
1,700 \\
1,900 \\
3,850 \\
4,510 \\
2,450 \\
2,000 \\
1,820 \\
1,900\end{array}$ & $\begin{array}{l}1,640 \\
1,240 \\
1,390 \\
1,120 \\
1,300 \\
2,890 \\
3,200 \\
1,700 \\
1,270 \\
1,000 \\
1,250\end{array}$ & $\begin{array}{l}100 \\
110 \\
100 \\
100 \\
100 \\
120 \\
120 \\
110 \\
110 \\
80 \\
100\end{array}$ & $\begin{array}{l}0.3 \\
0 \\
0 \\
0 \\
0 \\
.1 \\
0 \\
.1 \\
0 \\
.4 \\
.1\end{array}$ & $\begin{array}{l}0 \\
0 \\
\overline{0} \\
0 \\
\overline{0} \\
0 \\
0 \\
0 \\
0\end{array}$ & $\begin{array}{l}162 \\
143 \\
178 \\
143 \\
128 \\
218 \\
272 \\
192 \\
128 \\
117 \\
128\end{array}$ \\
\hline \multicolumn{11}{|c|}{ Wajir District } \\
\hline $\begin{array}{l}\text { "Gl Nur } \\
\text { Kanyuri } \\
\text { Wag Hala } \\
\text { Wajir Bor } \\
\text { Giriftu, Govern- } \\
\text { ment well. }\end{array}$ & $\begin{array}{l}-- \\
\overline{5} \overline{0} \\
-- \\
--\end{array}$ & $\begin{array}{l}7-1-72 \\
7-4-72 \\
7-3-72 \\
7-1-72 \\
7-7-72\end{array}$ & $\begin{array}{r}12 \\
4 \\
16 \\
6 \\
18\end{array}$ & $\begin{array}{l}7.4 \\
7.5 \\
7.5 \\
7.1 \\
7.8\end{array}$ & $\begin{array}{l}3,700 \\
4,400 \\
2,200 \\
2,800 \\
1,020\end{array}$ & $\begin{array}{r}\mathbf{2 , 4 9 0} \\
\mathbf{2 , 5 9 0} \\
1,320 \\
\mathbf{2 , 7 0 0} \\
\mathbf{7 0 5}\end{array}$ & $\begin{array}{l}55 \\
70 \\
40 \\
20 \\
80\end{array}$ & $\begin{array}{l}0 \\
0 \\
.2 \\
.1 \\
.2\end{array}$ & $\begin{array}{l}- \\
- \\
- \\
-\end{array}$ & $\begin{array}{r}228 \\
181 \\
87 \\
630 \\
16\end{array}$ \\
\hline $\begin{array}{l}\text { El Ben } \\
\text { Tarbaj } \\
\text { Buna, Sgt. Adan } \\
\text { Well. }\end{array}$ & $\begin{array}{l}-- \\
--\end{array}$ & $\begin{array}{l}7-7-72 \\
7-4-72 \\
7-6-72\end{array}$ & $\begin{array}{r}25 \\
8 \\
17\end{array}$ & $\begin{array}{l}7.5 \\
7.5 \\
7.9\end{array}$ & $\begin{array}{r}930 \\
1,100 \\
2,100\end{array}$ & $\begin{array}{r}690 \\
720 \\
1,440\end{array}$ & $\begin{array}{r}60 \\
80 \\
100\end{array}$ & 0.1 & $\begin{array}{l}- \\
-\end{array}$ & $\begin{array}{r}88 \\
132 \\
53\end{array}$ \\
\hline \multicolumn{11}{|c|}{ El Wak Township } \\
\hline $\begin{array}{l}\text { Primary School } \\
\text { "El Hachi } \\
\text { "El Kalo }\end{array}$ & $\begin{array}{l}\overline{54} \\
55\end{array}$ & $\begin{array}{l}7-4-72 \\
7-3-72 \\
7-3-72\end{array}$ & $\begin{array}{l}21 \\
21 \\
18\end{array}$ & $\begin{array}{l}\mathbf{7 . 3} \\
7.3 \\
7.3\end{array}$ & $\begin{array}{l}3,300 \\
4,000 \\
4,000\end{array}$ & $\begin{array}{l}2,500 \\
3,690 \\
3,670\end{array}$ & $\begin{array}{l}50 \\
40 \\
35\end{array}$ & $\begin{array}{l}0 \\
.1 \\
.1\end{array}$ & $\begin{array}{l}- \\
-\end{array}$ & $\begin{array}{l}683 \\
674 \\
659\end{array}$ \\
\hline
\end{tabular}


boreholes, northeastern Kenya-Continued

\begin{tabular}{|c|c|c|c|c|c|c|c|c|c|c|c|c|}
\hline Sodi- & $\begin{array}{l}\text { Po- } \\
\text { tas- } \\
\text { sium } \\
(\mathrm{K})\end{array}$ & $\begin{array}{c}\text { Bi- } \\
\text { car- } \\
\text { bon- } \\
\text { ate } \\
\left(\mathrm{HCO}_{3}\right)\end{array}$ & $\begin{array}{c}\text { Car- } \\
\text { bon- } \\
\text { ate } \\
\text { (CO3) }\end{array}$ & $\begin{array}{c}\text { Sul- } \\
\text { fate } \\
\left(\mathrm{SO}_{4}\right)\end{array}$ & $\begin{array}{l}\text { Chlo- } \\
\text { ride } \\
\text { (Cl) }\end{array}$ & $\begin{array}{c}\mathrm{Ni}- \\
\text { trate } \\
\left(\mathrm{NO}_{3}\right)\end{array}$ & $\begin{array}{c}\mathrm{Ni}- \\
\text { trite } \\
\left(\mathrm{NO}_{2}\right)\end{array}$ & $\begin{array}{l}\text { Fluo- } \\
\text { ride } \\
\text { (F) }\end{array}$ & $\begin{array}{c}\text { Hard- } \\
\text { ness } \\
\text { as } \\
\mathrm{CaCO}\end{array}$ & $\begin{array}{c}\text { Hard- } \\
\text { ness } \\
\text { non- } \\
\text { car- } \\
\text { bon- } \\
\text { ate }\end{array}$ & Aqui- & $\underset{\text { marks }}{\mathbf{R e}}$ \\
\hline \multicolumn{13}{|c|}{ Garissa District-Continued } \\
\hline $\begin{array}{r}3,927 \\
118\end{array}$ & $\begin{array}{r}78 \\
9\end{array}$ & -- & --- & $\begin{array}{r}3,910 \\
23\end{array}$ & $\begin{array}{r}5,900 \\
28\end{array}$ & $\begin{array}{l}2.2 \\
0\end{array}$ & $\begin{array}{l}0 \\
0\end{array}$ & $\begin{array}{r}3.2 \\
.5\end{array}$ & $\begin{array}{r}4,320 \\
.80\end{array}$ & --- & $\mathbf{P}$ & $\mathbf{S}$ \\
\hline 3,620 & 43 & $\overline{460}$ & & 4,800 & 3,570 & 0 & 0 & 1.0 & 2,070 & --- & $\mathbf{P}$ & $\mathbf{S}$ \\
\hline$\therefore$ & $\ldots$ & 338 & 48 & 1,440 & 1,880 & $\ldots$ & & & 160 & - & $\mathbf{P}$ & $\tilde{\mathbf{S}}$ \\
\hline 70 & 8 & 373 &.- & 60 & 50 & 0 & 0 & $\overline{1.0}$ & 200 & 0 & A & \\
\hline 62 & 15 & 396 & $\cdots$ & 51 & 140 & 5.3 & $<.03$ & 1.18 & 324 & 32 & $\mathbf{P}$ & \\
\hline 240 & 20 & 390 & 0 & 59 & 336 & 67 & $<.03$ & .54 & 436 & & $\mathbf{P}$ & \\
\hline 80 & 14 & 476 & 0 & 41 & 38 & 5.0 & .03 & .7 & 206 & 0 & $\mathbf{P}$ & \\
\hline 520 & 4.5 & 854 & 0 & 87 & 150 & 2.7 & .03 & 2.2 & 214 & 0 & $\mathbf{P}$ & \\
\hline 368 & 11 & 573 & 0 & 56 & 278 & .04 & .02 & .6 & 120 & 0 & $\mathbf{P}$ & \\
\hline 456 & 6 & 776 & 0 & 77 & 182 & .09 & .03 & .8 & 35 & 0 & $\mathbf{P}$ & \\
\hline 338 & 46 & 744 & 0 & 73 & 130 & 0 & .01 & 3.0 & 80 & 0 & $\mathbf{P}$ & \\
\hline 5,275 & 18 & 994 & 152,5 & 5933 & 3,650 & 1.7 & 1.4 & 5.2 & 80 & 0 & $\mathbf{P}$ & \\
\hline 425 & 7 & 847 & 0 & 83 & 136 & 1.1 & .03 & 1.5 & 76 & 0 & $\mathbf{P}$ & \\
\hline 2,540 & 13 & 1,698 & 98 & 850 & 2,700 & 2.8 & 2.9 & 6.7 & 94 & 0 & $\mathbf{P}$ & \\
\hline 245 & 9 & 569 & 0 & 60 & 82 & 0 & 0 & 1.3 & 52 & 0 & $\mathbf{P}$ & \\
\hline 236 & 8 & 508 & 24 & 133 & 49 & 1.3 & .01 & .9 & 50 & 0 & $\mathbf{P}$ & \\
\hline 123 & 15 & 359 & 31 & 17 & 69 & 4.4 & $\mathbf{T}$ & .2 & 142 & 0 & $\overrightarrow{\mathbf{P}}$ & \\
\hline 120 & 15 & 485 & 0 & 8 & 36 & 2.6 & $\mathbf{T}$ & .4 & 168 & 0 & $\mathbf{P}$ & \\
\hline 76 & 14 & 434 & & 61 & 124 & 8.0 & 0 & .7 & 35 & 18 & $\mathbf{P}$ & \\
\hline \multicolumn{13}{|c|}{ Isiolo District-Continued } \\
\hline & & 1,050 & & 126 & 135 & Pres & Pres & & 193 & & $\mathbf{A}$ & \\
\hline $\mathbf{3 , 6 0 0}$ & 13 & 3,100 & 422 & 1,630 & 3,100 & 57 & 3.3 & $2 . \overrightarrow{0}$ & 66 & 0 & $\mathbf{P}$ & \\
\hline 2,200 & 7.8 & 2,050 & 552 & 827 & 1,080 & 0 & .6 & 20 & 10 & & A & \\
\hline 3,860 & 18 & 2,430 & 996 & 973 & $\mathbf{2 , 5 5 0}$ & 4.4 & .7 & 12 & 40 & 0 & $\mathbf{A}$ & \\
\hline 2,860 & 26 & 2,920 & 312 & 800 & $\mathbf{2 , 4 7 0}$ & 1.3 & .1 & 37 & 14 & 0 & $\mathbf{P}$ & \\
\hline 2,900 & 32 & 1,680 & 312 & 1,230 & 2,720 & 4.4 & .13 & 7.6 & 32 & 0 & $\mathbf{P}$ & \\
\hline 7,560 & 24 & 2,640 & 504 & $\mathbf{3 , 4 7 0}$ & 8,150 & $\ldots$ & .13 & 12.5 & 52 & 0 & $\mathbf{P}$ & \\
\hline & 15 & 03 & & 15 & 20 & 0 & .08 & 0.4 & 234 & 0 & A & \\
\hline
\end{tabular}

shallow dug wells, northeastern Kenya

by Kenya Government Chemist's Department, Nairobi]

Depth: In metres below land surface.

Specific conductance: In micromhos at $25^{\circ} \mathrm{C}$.

Dissolved solids: Residue on evaporation at $180^{\circ} \mathrm{C}$.

\begin{tabular}{|c|c|c|c|c|c|c|c|c|c|c|c|}
\hline$\underset{\text { nesium }}{\text { Mags- }}$ & $\underset{(\mathrm{Na})}{\text { Sodium }}$ & $\begin{array}{l}\text { Potas- } \\
\text { sium } \\
\text { (K) }\end{array}$ & $\begin{array}{c}\text { Bicar- } \\
\text { bonate } \\
\text { (HCOs) }\end{array}$ & $\begin{array}{c}\text { Car- } \\
\text { bonate } \\
\left(\mathrm{CO}_{3}\right)\end{array}$ & $\begin{array}{c}\text { Sul- } \\
\text { fate } \\
\text { (SOA) }\end{array}$ & $\begin{array}{l}\text { Chlo- } \\
\text { ride } \\
\text { (Cl) }\end{array}$ & $\begin{array}{c}\mathrm{Ni}- \\
\text { trate } \\
\left(\mathrm{NO}_{3}\right)\end{array}$ & $\begin{array}{c}\mathrm{Ni}- \\
\text { trite } \\
\left(\mathrm{NO}_{2}\right)\end{array}$ & $\begin{array}{c}\text { Fluo- } \\
\text { ride } \\
\text { (F) }\end{array}$ & $\begin{array}{c}\text { Hard- } \\
\text { ness, } \\
\text { as } \\
\mathrm{CaCO}^{2}\end{array}$ & $\begin{array}{c}\text { Hard- } \\
\text { ness, } \\
\text { non- } \\
\text { car- } \\
\text { bonate } \\
\end{array}$ \\
\hline \multicolumn{12}{|c|}{ Wajir Township-Continued } \\
\hline $\begin{array}{r}\mathbf{6 7} \\
\mathbf{5 3} \\
25 \\
61 \\
\mathbf{5 3} \\
131 \\
\mathbf{1 5 8} \\
89 \\
61 \\
47 \\
60\end{array}$ & $\begin{array}{r}190 \\
100 \\
126 \\
80 \\
115 \\
280 \\
300 \\
200 \\
170 \\
140 \\
125\end{array}$ & $\begin{array}{l}29 \\
39 \\
68 \\
78 \\
91 \\
40 \\
40 \\
23 \\
23 \\
20 \\
20\end{array}$ & $\begin{array}{l}297 \\
286 \\
140 \\
315 \\
281 \\
344 \\
356 \\
349 \\
312 \\
261 \\
254\end{array}$ & $\begin{array}{l}7.0 \\
0 \\
0 \\
0 \\
0 \\
0 \\
0 \\
0 \\
0 \\
4.8 \\
0\end{array}$ & $\begin{array}{r}127 \\
107 \\
93 \\
103 \\
187 \\
280 \\
180 \\
125 \\
90 \\
103 \\
100\end{array}$ & $\begin{array}{r}\mathbf{5 6 0} \\
320 \\
330 \\
340 \\
240 \\
910 \\
\mathbf{1 , 1 2 0} \\
620 \\
340 \\
300 \\
290\end{array}$ & $\begin{array}{r}177 \\
177 \\
212 \\
89 \\
122 \\
177 \\
222 \\
78 \\
78 \\
199 \\
222\end{array}$ & $\begin{array}{l}0.01 \\
.01 \\
.01 \\
.20 \\
.01 \\
.01 \\
.01 \\
.01 \\
.01 \\
.01 \\
.05\end{array}$ & $\begin{array}{l}0.6 \\
.5 \\
.4 \\
.3 \\
.5 \\
.7 \\
.6 \\
.5 \\
.7 \\
.7 \\
.7\end{array}$ & $\begin{array}{r}\mathbf{6 8 4} \\
\mathbf{5 8 0} \\
\mathbf{5 4 7} \\
\mathbf{6 0 8} \\
\mathbf{5 4 0} \\
\mathbf{1 , 0 9 0} \\
\mathbf{1 , 3 4 0} \\
\mathbf{8 5 2} \\
\mathbf{5 7 6} \\
\mathbf{4 8 4} \\
\mathbf{5 6 8}\end{array}$ & $\begin{array}{r}440 \\
346 \\
453 \\
286 \\
310 \\
806 \\
1,048 \\
566 \\
320 \\
262 \\
360\end{array}$ \\
\hline \multicolumn{12}{|c|}{ Wajir District-Continued } \\
\hline $\begin{array}{r}116 \\
123 \\
64 \\
23 \\
61\end{array}$ & $\begin{array}{r}3 \overline{39} \\
232 \\
96 \\
130\end{array}$ & $\begin{array}{l}46 \\
75 \\
47 \\
39 \\
31\end{array}$ & $\begin{array}{l}275 \\
226 \\
262 \\
220 \\
500\end{array}$ & $\begin{array}{l}0 \\
0 \\
0 \\
0 \\
0\end{array}$ & $\begin{array}{r}140 \\
200 \\
133 \\
1,600 \\
57\end{array}$ & $\begin{array}{r}870 \\
880 \\
404 \\
111 \\
70\end{array}$ & $\begin{array}{c}214 \\
2.2 \\
106 \\
1.7 \\
5.5\end{array}$ & $\begin{array}{l}.10 \\
.20 \\
.03 \\
.60 \\
.01\end{array}$ & $\begin{array}{l}1.1 \\
.9 \\
1.8 \\
.7 \\
2.5\end{array}$ & $\begin{array}{r}1,050 \\
964 \\
483 \\
1,670 \\
292\end{array}$ & $\begin{array}{r}827 \\
779 \\
268 \\
1,490 \\
0\end{array}$ \\
\hline $\begin{array}{l}21 \\
31 \\
72\end{array}$ & $\begin{array}{r}53 \\
22 \\
338\end{array}$ & $\begin{array}{l}24 \\
66 \\
10\end{array}$ & $\begin{array}{l}299 \\
567 \\
580\end{array}$ & $\begin{array}{l}0 \\
0 \\
0\end{array}$ & $\begin{array}{r}112 \\
17 \\
160\end{array}$ & $\begin{array}{r}71 \\
29 \\
298\end{array}$ & $\begin{array}{c}13.3 \\
0 \\
17.7\end{array}$ & $\begin{array}{l}.01 \\
.70 \\
.10\end{array}$ & $\begin{array}{r}.7 \\
1.7 \\
3.5\end{array}$ & $\begin{array}{l}306 \\
458 \\
432\end{array}$ & $\begin{array}{r}163 \\
0 \\
0\end{array}$ \\
\hline \multicolumn{12}{|c|}{ El Wak Township-Continued } \\
\hline $\begin{array}{l}62 \\
74 \\
33\end{array}$ & $\begin{array}{r}88 \\
164 \\
198\end{array}$ & $\begin{array}{r}73 \\
104 \\
120\end{array}$ & $\begin{array}{l}134 \\
220 \\
110\end{array}$ & $\begin{array}{l}0 \\
0 \\
0\end{array}$ & $\begin{array}{l}1,570 \\
1,630 \\
1,870\end{array}$ & $\begin{array}{l}198 \\
330 \\
321\end{array}$ & $\begin{array}{l}26.6 \\
26.6 \\
11.1\end{array}$ & $\begin{array}{l}.01 \\
.01 \\
.01\end{array}$ & $\begin{array}{l}1.3 \\
1.5 \\
1.4\end{array}$ & $\begin{array}{l}1,970 \\
2,000 \\
1,780\end{array}$ & $\begin{array}{l}1,858 \\
1,815 \\
1,694\end{array}$ \\
\hline
\end{tabular}


TABLE 10.-Records of boreholes drilled in Precambrian Borehole: Serial numbers are assigned by Kenya Water Department to all boreholes in Kenya. The prefix, C-, should be added to all serial numbers listed in this table. Location: Name of town or village in or near which corresponding borehole is located. Approximate altitude: Measured by aneroid barometer, in metres above sea level.

Total depth of borehole: In metres below land surface.

Casing: Mild steel casing used to case most boreholes. Diameter, in millimetres. Bottom setting, in metres below land surface.

\begin{tabular}{|c|c|c|c|c|}
\hline Borehole & Location & $\begin{array}{c}\text { Year } \\
\text { completed }\end{array}$ & $\begin{array}{c}\text { Approximate } \\
\text { altitude }\end{array}$ & $\begin{array}{l}\text { Total } \\
\text { depth of } \\
\text { borehole }\end{array}$ \\
\hline 2440 & Buna & 1955 & 488 & 17.4 \\
\hline 2441 & Dibe & 1955 & 634 & 36.6 \\
\hline 2569 & Kiliwihiri _. & 1956 & 778 & 61.0 \\
\hline 3476 & Takabba & 1967 & 625 & 122.0 \\
\hline 3484 & L ando do & 1968 & 625 & 91.8 \\
\hline 3503 & do & 1968 & 622 & 64.0 \\
\hline 3515 & Gurar & 1968 & 778 & 122.2 \\
\hline 3527 & - _ do & 1968 & 900 & 32.0 \\
\hline 3528 & Takabba & 1968 & 625 & 91.5 \\
\hline 3541 & Helati & 1968 & 424 & 45.7 \\
\hline 3542 & Buna & 1968 & 488 & 18.3 \\
\hline 3543 & do & 1968 & 488 & 17.4 \\
\hline 3544 & - do & 1968 & 488 & 14.9 \\
\hline 3545 & do & 1968 & 488 & 9.2 \\
\hline 3549 & Buna & 1969 & 488 & 45.7 \\
\hline 3657 & Bute No. 1 & 1970 & 787 & 61.0 \\
\hline 3658 & Bute No. 2 & 1970 & 785 & 61.0 \\
\hline 3714 & Takabba & 1970 & 567 & 106.7 \\
\hline 3811 & Giriftu & 1972 & 299 & 128.7 \\
\hline 3829 & Aden Awale & 1972 & 386 & 91.5 \\
\hline 3848 & do - do & 1972 & 424 & 99.4 \\
\hline 3849 & Buna, northwest of & 1972 & 483 & 139.3 \\
\hline 3866 & Tuli Roba & 1972 & 509 & 152.4 \\
\hline 3872 & Ajao Hill & 1972 & 564 & 92.7 \\
\hline 3879 & Helati, southwest of & 1972 & 409 & 91.4 \\
\hline 3880 & Helati, northwest of & 1972 & 448 & 76.2 \\
\hline 3881 & Ali Gollo Hill & 1972 & 512 & 94.8 \\
\hline 3891 & Bute No. 3 & 1973 & 790 & 32.9 \\
\hline 3899 & Dambas & 1973 & 397 & 84.0 \\
\hline 3917 & Girfitu, northwest of & 1973 & 326 & 205.3 \\
\hline 3918 & do & 1973 & 351 & 158.0 \\
\hline 3931 & Bur Beit & 1973 & 458 & 152.0 \\
\hline
\end{tabular}


crystalline rocks, northeastern Kenya

Water-bearing zone: Position of first water-bearing zone encountered by the drill, in metres below land surface.

Static water level: In metres below land surface at time of completion. Owing to inconsistencies in measuring points, early data may be accurate only to 0.5 metres.

Pumping water level: ln metres below land surface.

Yield: In litres per minute at time of completion of well. $<6$, less than 6 .

Remarks: A, abandoned; B, brackish water; C, chemical analysis in table 8; D, dry; E, failed in 1973; $F$, fresh water; $S$, saline water; $U$, usable.

\begin{tabular}{|c|c|c|c|c|c|c|}
\hline \multicolumn{2}{|c|}{ Casing } & \multirow{2}{*}{$\begin{array}{c}\text { Water- } \\
\text { bearing } \\
\text { zone }\end{array}$} & \multirow{2}{*}{$\begin{array}{l}\text { Static } \\
\text { water } \\
\text { level }\end{array}$} & \multirow{2}{*}{$\begin{array}{c}\text { Pumping } \\
\text { water } \\
\text { level }\end{array}$} & \multirow[b]{2}{*}{ Yield } & \multirow[b]{2}{*}{ Remarks } \\
\hline Diameter & $\begin{array}{l}\text { Bottom } \\
\text { setting }\end{array}$ & & & & & \\
\hline 152 & 1.5 & 13.1 & 10.4 & -- & 48 & \\
\hline 152 & 100 & & & & $-\bar{c}$ & $\underset{C}{D}$ \\
\hline $204, \begin{array}{r}152 \\
152\end{array}$ & 19.2 & 52.4 & 52.4 & 61.0 & $<6$ & $\mathbf{S}$ \\
\hline 152 & -- & 75.0 & 72.0 & -- & $<0$ & D \\
\hline 152 & $\cdots$ & $-\cdots$ & -- & -- & $\cdots$ & D \\
\hline 152 & 50.3 & 103.7 & 97.6 & $-\ldots$ & $<6$ & \\
\hline 152 & 16.1 & 15.2 & 6.1 & -- & 9 & $\mathbf{B}, \mathbf{C}, \mathrm{U}$ \\
\hline 152 & -- & 18.0 & 16.8 & 17.7 & 49 & $\mathrm{~F}, \mathrm{C}$ \\
\hline 102 & --- & ---- & --- & --- & -.- & D \\
\hline 102 & -.- & & & --- & $\ldots$ & D \\
\hline 204 & -- & 12.8 & 10.1 & --- & $<6$ & 5 \\
\hline 102 & & & & -- & - & D \\
\hline 152 & 15.2 & 17.4 & 12.8 & --- & 53 & $\mathrm{~B}, \mathrm{C}, \mathrm{U}$ \\
\hline 152 & & 22.3 & 18.6 & -.- & 18 & $\mathrm{~F}, \mathrm{C}$ \\
\hline 152 & 19.2 & 20.1 & 17.1 & --- & 22 & $\mathbf{E}$ \\
\hline 152 & -- & & & -- & & D \\
\hline 152 & --- & 71.7 & 70.1 & --- & 6 & $\mathbf{S}, \mathbf{A}$ \\
\hline 152 & $\ldots$ & &.-- & $\ldots$ & & D \\
\hline 152 & --- & 57.9 & 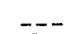 & $\ldots$ & 6 & A \\
\hline 152 & -.- & 54.9 & 38.7 & $\ldots$ & 6 & $A$ \\
\hline 152 & --- & 80.8 & 54.9 & $\ldots$ & 6 & A \\
\hline 152 & -- & -- & -- & --- & $\ldots$ & D \\
\hline 152 & --- & -.-- & --- & --- & -- & D \\
\hline 152 & 4.0 & 35.1 & 28.7 & $\ldots$ & 6 & S, C \\
\hline 152 & 11.6 & & 36.0 & $\ldots$ & 31 & $B, C, U$ \\
\hline 152 & 23.8 & 21.4 & 21.1 & 31.5 & 23 & $\mathrm{~F}, \mathrm{C}$ \\
\hline 152 & 11.6 & 31.4 & 31.1 & $\ldots$ & 151 & S, C \\
\hline 152 & -.. & 68.0 & 65.9 & -.- & 14 & S, C, U \\
\hline 152 & -- & 67.1 & 57.9 & $-\ldots$ & 6 & S, C \\
\hline 152 & --- & 116.0 & 85.0 & -.- & 6 & $\mathrm{~B}, \mathrm{C}, \mathrm{U}$ \\
\hline
\end{tabular}


TABLE 11.-Records of boreholes drilled in

Borehole: Serial numbers are assigned by Kenya Water Department to all boreholes in Kenya. The prefix, $P_{-}$, should be added to the first three serial numbers in this table and the prefix, C-, to the rest.

Location: Name of town or village in or near which corresponding borehole is located.

Approximate altitude: Measured by aneroid barometer, in metres above sea level.

Total depth of borehole: In metres below land surface.

Casing: Mild steel casing used to case most boreholes. Diameter, in millimetres. Bottom setting, in metres below land surface.

Water-bearing zone: Position of first water-bearing zone encountered by the drill, in metres below land surface.

\begin{tabular}{|c|c|c|c|c|}
\hline Borehole & Location & $\begin{array}{l}\text { Year } \\
\text { com- } \\
\text { pleted }\end{array}$ & $\begin{array}{c}\text { Approxi- } \\
\text { mate } \\
\text { attitude }\end{array}$ & $\begin{array}{l}\text { Total } \\
\text { depth of } \\
\text { borehole }\end{array}$ \\
\hline 146 & Wajir Bor & 1931 & 204 & 124.4 \\
\hline 160 & Aus Manduli & 1931 & 357 & 109.8 \\
\hline 184 & War Gedud . & 1934 & 549 & 164.7 \\
\hline 2615 & "Bur Mansa & 1956 & 488 & 100.6 \\
\hline 2616 & Finno & 1956 & 458 & 91.5 \\
\hline 3155 & Wajir & 1964 & 265 & 186.4 \\
\hline 3306 & - & 1964 & 265 & 263.0 \\
\hline 3307 & Takabba - & 1968 & 618 & 169.3 \\
\hline 3539 & Tarbaj _-- & 1968 & 397 & 113.4 \\
\hline 3566 & Ileli Dika & 1968 & 596 & 167.7 \\
\hline 3567 & War Gedud & 1968 & 537 & 129.0 \\
\hline 3568 & - & 1969 & 567 & 86.6 \\
\hline 3569 & - $1-2-1-2-1-2-1$ & 1969 & 604 & 84.5 \\
\hline 3570 & - - - - - & 1969 & 473 & 126.6 \\
\hline 3571 & - - & 1969 & 445 & 125.0 \\
\hline 3572 & - - - - & 1969 & 393 & 125.0 \\
\hline 3573 & - & 1969 & 418 & 85.4 \\
\hline 3574 & - - do & 1969 & 323 & 76.2 \\
\hline 3668 & 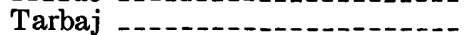 & 1970 & 389 & 241.0 \\
\hline 3669 & do & 1970 & 380 & 61.0 \\
\hline 3686 & Aus Manduli & 1970 & 404 & 183.0 \\
\hline 3690 & Mansa Guda & 1970 & 519 & 183.0 \\
\hline 3696 & Asahaba & 1970 & 604 & 122.0 \\
\hline 3828 & 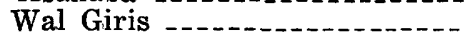 & 1972 & 175 & 224.2 \\
\hline 3850 & El Wak & 1972 & 445 & 133.6 \\
\hline 3851 & "Asahaba & 1972 & 604 & 76.2 \\
\hline 3861 & - do & 1972 & 604 & 88.7 \\
\hline 3865 & War Gedud & 1972 & 543 & 244.0 \\
\hline 3914 & Dambas, south of & 1973 & 381 & 149.3 \\
\hline
\end{tabular}


Mesozoic sedimentary rocks, northeastern Kenya

Aquifer: K, Cretaceous sedimentary rocks; J, Jurassic sedimentary rocks; $K$, Triassic sedimentary rocks.

Static water level: In metres below land surface at time of completion. Owing to inconsistencies in measuring points, early data may be accurate only to 0.5 metres.

Pumping water level: In metres below land surface.

Yield: In litres per minute at time of completion. $<6$, less than 6 .

Remarks: A, abandoned; B, brackish water; C, chemical analysis in table 8; D, dry; E, casing slotted 98.5 to 110.7 metres; G, polyvinyl chloride screen from 47.3 to 76.2 metres; S, saline water.

\begin{tabular}{|c|c|c|c|c|c|c|c|}
\hline \multicolumn{2}{|c|}{ Casing } & \multirow{2}{*}{$\begin{array}{c}\text { Water- } \\
\text { bearing } \\
\text { zone }\end{array}$} & \multirow[b]{2}{*}{ Aquifer } & \multirow{2}{*}{$\begin{array}{l}\text { Static } \\
\text { water } \\
\text { level }\end{array}$} & \multirow{2}{*}{$\begin{array}{c}\text { Pumping } \\
\text { water } \\
\text { level }\end{array}$} & \multirow[b]{2}{*}{ Xield } & \multirow[b]{2}{*}{ Remarks } \\
\hline Diameter & $\begin{array}{l}\text { Bottom } \\
\text { setting }\end{array}$ & & & & & & \\
\hline & & & $\mathbf{J}$ & & & & D \\
\hline \multirow{3}{*}{$\begin{array}{l}158 \\
152 \\
152\end{array}$} & 2.0 & \multirow{4}{*}{$\begin{array}{r}106.7 \\
146.4 \\
90.9 \\
79.3\end{array}$} & J & 79.3 & $-\ldots$ & 6 & \\
\hline & $\ldots$ & & $\mathrm{K}$ & & -..- & 15 & \\
\hline & & & $\bar{K}$ & 90.9 & -..- & $<6$ & B \\
\hline 204 & 13.7 & & $\mathrm{~K}$ & 57.9 & --- & 65 & $\mathrm{~B}, \mathrm{C}$ \\
\hline 204 & 125.3 & ---- & 下 & 13.7 & ---- & 17 & $B, C$ \\
\hline 204 & 114.4 & -.-- & E & 14.6 & --.- & 22 & $\mathrm{~B}, \mathrm{C}$ \\
\hline 204,152 & $\ldots$ & -.-- & $\mathrm{J}$ & -- & $-\ldots$ & -... & $\mathrm{D}$ \\
\hline 152 & -... & -..- & 下 & ---- & $\ldots$ & -.-.- & D \\
\hline 152 & $\ldots$ & ---- & $\mathbf{K}$ & ---- & - . - & $-\ldots$ & D \\
\hline 120 & $\ldots$ & --- & $\mathrm{K}$ & --.- & -..- & --- & D \\
\hline 102 & & & $\mathrm{~K}$ & --- & --- & -- & D \\
\hline 102 & 84.5 & 51.8 & $\mathbf{K}$ & 46.6 & $\ldots$ & 38 & B, C \\
\hline 120 & $-\cdots$ & $\ldots$ & $\mathrm{K}$ & & --- & & \\
\hline 120 & $-\ldots$ & -.- & $\mathbf{K}$ & 70.4 & $\ldots-$ & 53 & B, C \\
\hline 204 & 12.2 & -... & $\mathbf{K}$ & 42.1 & 46.7 & 91 & B, C \\
\hline 102 & 83.9 & $\ldots$ & $\overline{\mathbf{K}}$ & 55.8 & --.- & 38 & B \\
\hline 152 & 30.5 & $\ldots$ & $\vec{J}$ & 33.9 & -..- & $50-75$ & B \\
\hline 152 & --- & $-\ldots$ & 下 & $\ldots$ & ---- & -.- & D \\
\hline 152 & --- & 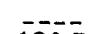 & k & & 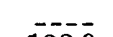 & & D \\
\hline 152 & $-\ldots$ & 120.5 & $\mathbf{J}$ & 106.7 & 133.9 & 17 & $\mathrm{~B}, \mathrm{C}$ \\
\hline 152 & & & E & & & & \\
\hline 152 & 110.7 & 53.4 & $\mathbf{K}$ & 45.1 & 114.3 & 13 & B, E \\
\hline 152 & .... & 163.2 & $\mathbf{J}$ & 163.2 & .... & $<6$ & $A, C, S$ \\
\hline 152 & -- & 42.7 & $\mathbf{K}$ & 36.9 & --- & $<6$ & A, C, S \\
\hline 152 & 48.8 & $-\ldots$ & $\vec{K}$ & 45.4 & $-\ldots$ & 27 & $\mathrm{~B}, \mathrm{C}, \mathrm{G}$ \\
\hline $15 \overline{2}$ & 64.3 & -... & $\overline{\mathbf{K}}$ & 46.3 & 85.9 & 47 & C, B \\
\hline 152 & 74.1 & $\ldots$ & $\mathbf{K}$ & 64.0 & $\ldots$ & 14 & C, B \\
\hline 152 & $\ldots-$ & 95.4 & E & 90.9 & --- & $<6$ & $\mathbf{C}, \mathbf{A}, \mathbf{B}$ \\
\hline
\end{tabular}


TABLE 12.-Records of boreholes screened Borehole: Serial numbers are assigned by Kenya Water Department to all boreholes in Kenya. The prefix, SA-, should be added to the first three serial numbers in this table and the prefix, C-, to the rest.

Location: Name of town or village in or near which corresponding borehole is located.

Approximate altitude: Measured by aneroid barometer, in metres above sea level.

Total depth of borehole: In metres below land surface.

Casing: Mild steel casing used to case most boreholes. Diameter, in millimetres. Bottom setting, in metres below land surface.

Screen: Perforated interval, in metres below land surface. Slot opening, in millimetres.

\begin{tabular}{|c|c|c|c|c|c|}
\hline Borehole & Location & $\begin{array}{l}\text { Year } \\
\text { com- } \\
\text { pleted }\end{array}$ & $\begin{array}{c}\text { Ap- } \\
\text { proxi- } \\
\text { mate } \\
\text { alti- } \\
\text { tude }\end{array}$ & $\begin{array}{c}\text { Total } \\
\text { depth } \\
\text { of } \\
\text { bore- } \\
\text { hole }\end{array}$ & $\begin{array}{c}\text { Casing } \\
\text { Diameter }\end{array}$ \\
\hline 19 & Habaswein, & 1940 & 200 & 20.7 & 152 \\
\hline 20 & Wajir, southwest of & 1940 & 233 & 107.0 & 152 \\
\hline 69 & Liboi & 1941 & 98 & 90.9 & 152 \\
\hline 96 & El Dera & 1940 & 354 & 124.4 & 204 \\
\hline 100 & Habaswein, west of & 1940 & 200 & 22.3 & 152 \\
\hline 2439 & Sabena & 1955 & 192 & 61.0 & 152 \\
\hline 2485 & Dadaab & 1955 & 130 & 128.4 & 152 \\
\hline 2511 & Habaswein, west of & 1955 & 200 & 61.0 & 152 \\
\hline 2570 & Mandera & 1956 & 323 & 41.5 & 152 \\
\hline 2571 & Mandera & 1956 & 232 & 41.8 & 204 \\
\hline 2643 & Dif ..... & 1956 & 153 & 122.0 & 152 \\
\hline 2685 & Liboi _... & 1957 & 102 & 93.9 & 152. \\
\hline 2686 & Alinjugal & 1957 & 130 & 111.0 & 152 \\
\hline 2687 & Garissa -- & 1957 & 146 & 54.9 & 204 \\
\hline 2718 & Kolbio --- & 1957 & 65 & 78.1 & 204 \\
\hline 2719 & -.--do $\quad-$ & 1957 & 55 & 79.3 & 152 \\
\hline 3033 & Fafi & 1960 & 135 & 137.2 & 152 \\
\hline 3038 & Galma Galla & 1960 & 84 & 106.7 & 102 \\
\hline 3041 & Lagh Bogal & 1960 & 226 & 175.4 & $15 \overline{2}$ \\
\hline 3070 & Bata & 1960 & 33 & 97.6 & 127 \\
\hline 3085 & Wel Merer & 1960 & 129 & 128.1 & 204,127 \\
\hline 3110 & Sabule & 1961 & 142 & 183.0 & 127 \\
\hline 3120 & Mararani -. & 1961 & 31 & 73.2 & 127 \\
\hline 3218 & Habaswein - & 1963 & 221 & 143.9 & 152 \\
\hline 3224 & Walu & 1962 & 88 & 123.5 & \\
\hline 3240 & "Darken -- & 1963 & 128 & 140.3 & $10 \overline{2}$ \\
\hline 3297 & Mandera - & 1965 & 232 & 45.7 & 120 \\
\hline 3406 & Wel Merer & 1966 & 148 & 154.0 & 127 \\
\hline 3411 & "Kurdi & 1966 & 124 & 140.3 & 127 \\
\hline 3540 & Giriftu & 1968 & 302 & 55.8 & 204 \\
\hline 3591 & Garissa & 1968 & 210 & 231.8 & 152 \\
\hline 3592 & - -- do & 1968 & 210 & 231.8 & 152 \\
\hline 3628 & Kolbio & 1969 & 55 & 73.2 & \\
\hline 3635 & Mado Gashi . & 1969 & 253 & 7.0 & 152 \\
\hline 3636 & - do & 1969 & 253 & 188.2 & 152 \\
\hline 3637 & Giriftu & 1970 & 302 & 82.0 & 152 \\
\hline 3645 & Habaswein, west of & 1970 & 200 & 38.7 & $15 \overline{2}$ \\
\hline 3653 & "Kalalut _. & 1970 & 166 & 18.3 & 152,102 \\
\hline 3654 & Habaswein & 1970 & 220 & 134.5 & 152 \\
\hline 3655 & do & 1970 & 204 & 120.2 & $15 \overline{2}$ \\
\hline 3656 & Giriftu & 1970 & 302 & 20.4 & 152 \\
\hline 3667 & Liboi & 1970 & 101 & 99.7 & 152 \\
\hline 3684 & Wardeglo & 1970 & 119 & 119.2 & 152 \\
\hline 3685 & "Kalalut & 1970 & 191 & 108.3 & 152 \\
\hline 3687 & Meri & 1970 & 153 & 122.0 & $15 \overline{2}$ \\
\hline 3695 & Dadaab & 1970 & 128 & 130.8 & $15 \overline{2}$ \\
\hline 3697 & Meri, west of & 1970 & 156 & 151.9 & 152 \\
\hline 3715 & Meri, southwest of & 1971 & 159 & 136.9 & 152 \\
\hline 3726 & Khot Khot & 1971 & 157 & 140.0 & 152 \\
\hline 3727 & Meri, northwest of & 1971 & 174 & 144.3 & $15 \overline{2}$ \\
\hline
\end{tabular}


in the Merti aquifer, northeastern Kenya

Water-bearing zone: Position of first water-bearing zone encountered by the drill, in metres below land surface.

Static water level: In metres below land surface at time of completion. Owing to inconsistencies in measuring points, early data may be accurate only to 0.5 metre.

Drawdown: In metres below static water level.

Yield: In litres per minute at time of completion. $<6$, less than 6 .

Remarks: A, abandoned; B, brackish water; C, chemical analysis in table 8; D, dry; E, taps water in alluvium; F, fresh water; $G$, deepened and screened in 1970; $H$, replaced by $C-$ 3902; I, replaced by C-3831; J, Johnson stainless steel screen; $\mathbf{K}$, casing broken; $\mathrm{O}$, observation borehole; $\mathbf{P}$, polyvinyl chloride screen; $\mathrm{S}$, saline water; $\mathrm{T}$, test hole; U, usable.

\begin{tabular}{|c|c|c|c|c|c|c|c|}
\hline \multirow{2}{*}{$\frac{\text { Casing-Con. }}{\begin{array}{c}\text { Bottom } \\
\text { setting }\end{array}}$} & \multicolumn{2}{|c|}{ Screen } & \multirow{2}{*}{$\begin{array}{c}\text { Water- } \\
\text { bearing } \\
\text { zone }\end{array}$} & \multirow{2}{*}{$\begin{array}{l}\text { Static } \\
\text { water } \\
\text { level }\end{array}$} & \multirow[b]{2}{*}{$\begin{array}{l}\text { Draw- } \\
\text { down }\end{array}$} & \multirow[b]{2}{*}{ Yield } & \multirow[b]{2}{*}{ Remarks } \\
\hline & $\begin{array}{c}\text { Per- } \\
\text { forated } \\
\text { interval }\end{array}$ & $\begin{array}{c}\text { Slot } \\
\text { opening }\end{array}$ & & & & & \\
\hline 19.8 & $-\cdots+-\infty$ & $-\cdots$ & 20.3 & 15.8 & -- & 151 & $\mathbf{E}$ \\
\hline 100.0 & & $\ldots$ & 95.8 & & - & & $\mathbf{A}$ \\
\hline 87.5 & $87.5-90.9$ & $-\ldots$ & 88.4 & 86.0 & - & 30 & \\
\hline 123.8 & 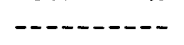 & ---- & & 108.3 & -- & $-z=$ & $\mathbf{A}, \mathbf{S}$ \\
\hline 17.7 & $-\cdots--\cdots$ & ---- & 17.7 & 14.3 & -- & 55 & \\
\hline $1 \overline{25.3}$ & $125.3-128.4$ & $0 . \overline{63}$ & $10 \overline{5.2}$ & $\overline{103.1}$ & $18 . \overline{3}$ & $\overline{7} \overline{6}$ & $\mathrm{C}, \mathrm{F}, \mathrm{G}$ \\
\hline$\overline{29 . \overline{3}}$ & $29.3-41.5$ & $-\cdots$ & 33.6 & 33.6 & 1.5 & -- & $\mathbf{C}, \mathbf{B}, \mathbf{E}$ \\
\hline 29.6 & $29.6-41.8$ & $-n$ & 00.0 & 33.6 & 1.5 & $\overline{9} \overline{1}$ & C, B, E \\
\hline & -- & $\ldots$ & 112.8 & 105.2 & & 65 & $\mathrm{~A}, \mathrm{C}, \mathrm{S}$ \\
\hline 93.9 & & -...- & 91.2 & 91.2 & $\overline{2.1}$ & 65 & \\
\hline 84.8 & $84.8-109.2$ & $\ldots$ & 108.0 & 108.0 & -- & 45 & C, \\
\hline--- & - & $-\ldots$ & 42.7 & 42.7 & -- & 23 & \\
\hline--- & $---\infty---$ & ---- & 70.1 & 70.1 & 4.6 & 65 & A, C, S \\
\hline & 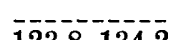 & $-\ldots$ & 61.9 & 61.9 & 2.1 & 65 & $\mathrm{~A}, \mathrm{C}, \mathrm{S}$ \\
\hline $\begin{array}{r}123.8 \\
92.1\end{array}$ & $123.8-134.2$ & ---- & 111.3 & 111.3 & -- & 38 & $A, C, S$ \\
\hline & 92.1-101.5 & $-\cdots$ & 155.5 & $\begin{array}{r}70.4 \\
118.9\end{array}$ & $\overline{3.1}$ & $\begin{array}{l}28 \\
95\end{array}$ & $\begin{array}{l}\text { A, C, S } \\
\text { A, C, S }\end{array}$ \\
\hline$\overline{83 . \overline{9}}$ & $83.9-97.6$ & $-\cdots$ & $\begin{array}{l}100.0 \\
-\ldots\end{array}$ & 25.3 & $\begin{array}{l}0.1 \\
--\end{array}$ & 38 & A, C, S \\
\hline 115.3 & $115.3-128.1$ & $-n-1$ & -.- & 115.3 & - & 38 & \\
\hline 126.9 & $126.9-140.3$ & $\ldots$ & $-\ldots$ & 123.5 & $\ldots$ & 36 & A, C, F \\
\hline 57.0 & $57.0-70.4$ & $\ldots$ & & 36.6 & & 41 & \\
\hline 131.7 & $131.7-143.9$ & --- & 132.7 & 126.3 & $\overline{4 . \overline{3}}$ & 85 & \\
\hline & & $-\cdots$ & --- & 86.0 & -- & 8 & $\mathrm{~S}$ \\
\hline 125.9 & $125.9-139.7$ & $\ldots$ & 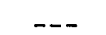 & 108.3 & & 30 & \\
\hline 38.1 & $38.1-45.7$ & $\ldots$ & 33.3 & 31.4 & 12.5 & 73 & $\mathrm{~B}, \mathrm{C}, \mathrm{E}$ \\
\hline 134.2 & $134.2-152.5$ & $\ldots-\ldots$ & 148.8 & 141.8 & 4.6 & 49 & \\
\hline 121.1 & $121.1-139.4$ & -..-- & & 132.7 & 4.6 & 36 & $\mathbf{S}$ \\
\hline$\ldots$ & - n & 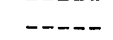 & 11.6 & 14.9 & -- & 10 & A \\
\hline & & -..-- & - & 136.6 & -- & 10 & \\
\hline & & $-\ldots$ & & 151.0 & -- & 27 & \\
\hline 54.9 & $54.9-73.2$ & $\ldots$ & 60.4 & 60.4 & -- & 13 & $\mathbf{S}$ \\
\hline 1.0 & $1.0-\quad 7.0$ &.--- & 2.4 & 2.4 & -- & --- & \\
\hline--- & - & ---- & 181.5 & 135.4 & -- & --- & $\mathrm{A}, \mathrm{C}, \mathrm{S}$ \\
\hline--- & - - - - - & ---- & 13.1 & 36.0 & -- & --- & $\mathrm{K}$ \\
\hline 15.2 & $15.2-18.3$ & 0.78 & 15.2 & -- & -- & -- & \\
\hline 131.1 & $131.1-134.2$ & 0.58 & 126.6 & 122.9 & $\overline{3.1}$ & $\overline{114}$ & C, F, J \\
\hline 117.1 & $117.1-120.2$ & 0.50 & & 105.5 & 4.9 & 114 & \\
\hline 96 & & & 13.1 & 13.1 & & & \\
\hline $\begin{array}{r}96.6 \\
113.1\end{array}$ & $96.6-99.7$ & 0.50 & $\begin{array}{r}90.3 \\
108.3\end{array}$ & 90.3 & 2.7 & $\begin{array}{l}170 \\
160\end{array}$ & C, F, \\
\hline $\begin{array}{l}113.1 \\
105.2\end{array}$ & $\begin{array}{l}113.1-119.2 \\
105.2-108.3\end{array}$ & $\begin{array}{l}1.25 \\
0.50\end{array}$ & $\begin{array}{r}100.5 \\
88.1\end{array}$ & $\begin{array}{r}102.8 \\
87.2\end{array}$ & 4.2 & 114 & \\
\hline 118.6 & $118.6-121.7$ & 0.50 & $\begin{array}{r}105.2 \\
\end{array}$ & 100.0 & 17.1 & 36 & C, F, J \\
\hline 127.7 & $127.7-130.8$ & 0.50 & 116.5 & 106.7 & 12.5 & 151 & C, F, J \\
\hline 147.0 & $147.0-151.6$ & 0.37 & 103.7 & 98.5 & 4.0 & 76 & C, F, P \\
\hline 131.7 & $131.7-136.9$ & 0.78 & 103.7 & 100.6 & 30.5 & 88 & $\mathrm{C}, \mathrm{F}, \mathrm{P}$ \\
\hline 133.3 & $133.3-140.0$ & 1.55 & 110.1 & 105.8 & 5.5 & 178 & C, F, P \\
\hline 140.3 & $140.3-143.4$ & 0.37 & 112.2 & 105.5 & 13.1 & 135 & $\mathbf{C}, \mathbf{F}, \mathbf{J}$ \\
\hline
\end{tabular}


TABLE 12.-Records of boreholes screened in the

\begin{tabular}{|c|c|c|c|c|c|}
\hline \multirow{2}{*}{ Borehole } & \multirow{2}{*}{ Location } & \multirow{2}{*}{$\begin{array}{c}\text { Year } \\
\text { com- } \\
\text { pleted }\end{array}$} & \multirow{2}{*}{$\begin{array}{c}\text { Ap- } \\
\text { proxi- } \\
\text { mate } \\
\text { alti-1 } \\
\text { tude }\end{array}$} & \multirow{2}{*}{$\begin{array}{c}\text { Total } \\
\text { depth } \\
\text { of } \\
\text { bore- } \\
\text { hole }\end{array}$} & \multirow{2}{*}{$\frac{\text { Casing }}{\text { Diameter }}$} \\
\hline & & & & & \\
\hline 3751 & Meri, west of & 1971 & 160 & 133.6 & 152 \\
\hline 3752 & Meri, northwest of & 1971 & 174 & 151.6 & 152 \\
\hline 3753 & Lorian Swamp & 1971 & 188 & 113.7 & $15 \overline{2}$ \\
\hline 3769 & Hara Khot Khot - & 1971 & 177 & 132.1 & 152 \\
\hline 3770 & Dadaab, west of - & 1971 & 171 & 165.3 & 152,127 \\
\hline 3791 & Lorian Swamp - & 1972 & 189 & 122.9 & 152 \\
\hline 3788 & Meri, southeast of & 1972 & 148 & 119.5 & 152 \\
\hline 3792 & "Kalalut _. & 1972 & 189 & 112.8 & $15 \overline{2}$ \\
\hline 3804 & "Kalalut, west of & 1972 & 186 & 158.6 & 152 \\
\hline 3805 & Sericho & 1972 & 239 & 91.5 & 152 \\
\hline 3814 & - & 1972 & 236 & $\mathbf{5 1 . 8}$ & 152 \\
\hline 3820 & Sabule & 1972 & 143 & 128.7 & $15 \overline{2}$ \\
\hline 3821 & - - do _- & 1972 & 139 & 147.9 & 152 \\
\hline 3822 & Sericho _-....- & 1972 & 229 & 125.0 & 152 \\
\hline 3830 & Habaswein, northwest of & 1972 & 216 & 129.0 & 152 \\
\hline 3831 & Alinjugul & 1972 & 130 & 134.8 & 152 \\
\hline 3852 & Hagadera & 1972 & 127 & 146.7 & 152 \\
\hline 3853 & Merti & 1972 & 293 & 67.1 & 152 \\
\hline 3860 & Meri, south of & 1972 & 151 & 134.8 & 152 \\
\hline 3864 & Merti _... & 1972 & 290 & 30.8 & 152 \\
\hline 3877 & Sabule, northwest of & $197 \overline{3}$ & 146 & 132.0 & 152 \\
\hline 3878 & - do & 1973 & 144 & 137.2 & 152 \\
\hline 3893 & Hadado & 1973 & 302 & 213.4 & 152 \\
\hline 3902 & Liboi & 1973 & 102 & 103.7 & 152 \\
\hline 3915 & Hadado, east of & 1973 & 287 & 176.8 & 152 \\
\hline
\end{tabular}

TABLE 13.-Logs of selected boreholes in northeastern Kenya

C-3636 near Mado Gashi

Altitude 253 metres

Drilled in 1969

Lithologic character

Thickness Depth

Holocene

Silt and clay, sandy, gray

$3.1 \quad 3.1$

Pliocene (Merti Beds)

Clay, brown; streaks of sandy clay

Clay, reddish-brown, hard; pebbles of quartz and weathered granite

$27.4 \quad 30.5$

Clay, gray and red, hard, sandy

$93.0 \quad 123.5$

$57.3 \quad 180.8$

Sand, fine to coarse, slightly clayey; some gravel; pebbles of quartz and weathered granite 
Merti aquifer, northeastern Kenya-Continued

\begin{tabular}{|c|c|c|c|c|c|c|c|}
\hline \multirow{2}{*}{$\frac{\text { Casing-Con. }}{\begin{array}{l}\text { Bottom } \\
\text { setting }\end{array}}$} & \multicolumn{2}{|c|}{ Screen } & \multirow[b]{2}{*}{$\begin{array}{c}\text { Water } \\
\text { bearing } \\
\text { zone }\end{array}$} & \multirow[b]{2}{*}{$\begin{array}{c}\text { Static } \\
\text { water } \\
\text { level }\end{array}$} & \multirow[b]{2}{*}{$\begin{array}{l}\text { Draw- } \\
\text { down }\end{array}$} & \multirow[b]{2}{*}{ Yield } & \multirow[b]{2}{*}{ Remarks } \\
\hline & $\begin{array}{c}\text { Per- } \\
\text { forated } \\
\text { interval }\end{array}$ & $\begin{array}{c}\text { Slot } \\
\text { opening }\end{array}$ & & & & & \\
\hline 127.5 & $127.5-133.6$ & 0.37 & 110.7 & 101.9 & 12.2 & 114 & $C, F, P$ \\
\hline 148.5 & $148.5-151.6$ & 0.37 & 108.6 & 92.1 & & 122 & C, F, J \\
\hline 107.6 & $107.6-113.7$ & 0.37 & 94.5 & 91.2 & 10.4 & 76 & $\mathrm{C}, \mathrm{F}, \mathrm{P}$ \\
\hline 126.0 & $126.0-132.1$ & 0.37 & 103.7 & 99.4 & 25.9 & 129 & $\mathbf{C}, \mathbf{F}, \mathbf{P}$ \\
\hline 159.2 & $159.2-165.3$ & 0.37 & 145.8 & 137.5 & & 61 & $\mathbf{C}, \mathbf{F}$, \\
\hline 119.5 & $119.5-122.6$ & 0.37 & 94.5 & 93.6 & 5.2 & 106 & $\mathbf{C}, \mathbf{F}, \mathbf{J}$ \\
\hline 113.7 & $113.7-119.5$ & 0.37 & 101.5 & 98.2 & 14.0 & 94 & C, F, P \\
\hline 109.7 & $109.7-112.8$ & 0.50 & 100.6 & 96.1 & 11.3 & 76 & C, F, J \\
\hline 152.5 & $152.5-158.6$ & 0.20 & 114.4 & 98.2 & 21.7 & 83 & C, S, U \\
\hline$-\cdots-$ & -------- & --- & 19.8 & 22.3 & -- & --- & $A, C, S$ \\
\hline & & - & 15.2 & 26.5 & & & $A, C, S$ \\
\hline 125.6 & $125.6-128.7$ & 0.37 & 96.1 & 93.6 & 11.6 & 135 & C, F, J \\
\hline 144.8 & $144.8-147.9$ & 0.25 & 146.4 & 125.0 & 14.6 & 75 & C, F, J \\
\hline 113.1 & $113.1-119.2$ & 0.37 & 100.6 & 79.9 & & 50 & C, S, U \\
\hline 126.0 & $125.9-129.0$ & 0.50 & 118.9 & 107.3 & 16.5 & 182 & C, F, J \\
\hline 132.0 & $131.7-134.8$ & 0.25 & & 108.3 & 23.5 & 72 & \\
\hline 143.8 & $143.6-146.7$ & 0.25 & 108.6 & 107.6 & -- & 114 & \\
\hline 132.0 & $131.7-134.8$ & 0.25 & 99.1 & 97.6 & & 78 & $\begin{array}{l}\mathrm{C}, \mathrm{S} \\
\mathrm{F}, \mathrm{J}\end{array}$ \\
\hline & & & & 12.5 & $\overline{8.5}$ & 227 & \\
\hline 125.0 & $125.0-128.1$ & 0.25 & 97.0 & 94.8 & -- & 135 & $\mathrm{~J}$ \\
\hline & & & & 94.5 & & & \\
\hline 202.1 & $202.0-205.1$ & $0 . \overline{37}$ & 195.2 & 190.7 & - & 38 & $\mathrm{C}, \mathbf{F}, \mathrm{J}$ \\
\hline 98.0 & $98.0-101.1$ & 0.50 & 91.5 & 90.9 & -- & 151 & $\mathrm{C}, \mathrm{F}, \mathrm{J}$ \\
\hline 112.0 & $112.0-117.0$ & 0.78 & 106.1 & 102.2 & - & 125 & $\mathrm{C}, \mathrm{F}, \mathrm{J}$ \\
\hline
\end{tabular}

TABLE 13.-Logs of selected boreholes in northeastern Kenya-Continued

\section{C-3655 near Habaswein}

Altitude 204 metres

Lithologic character

Pliocene (Merti Beds)

Clay, gray and red, hard; streaks of sandy and pebbly clay

Sand, medium to coarse, white and yellow; some gravel; pebbles of quartz and weathered granite; some clay -..-

Clay, gray and red, sandy and pebbly --

\section{Drilled in 1970}

$\begin{array}{cc}\text { Thickness } & \text { Depth } \\ \text { (metres) } & \text { (metres) }\end{array}$

$112.8 \quad 112.8$

$\begin{array}{ll}7.7 & 120.5\end{array}$

$48.8 \quad 169.3$ 
TABLE 13.-Logs of selected boreholes in northeastern Kenya-Continued

\section{C-3668 near Tarbaj}

Altitude 389 metres

Drilled in 1970

Lithologic character

Thickness Depth

(metres) (metres)

Holocene and Triassic (?)

Clay, sandy and pebbly, red; pebbles of weathered granite and sandstone --

$32.0 \quad 32.0$

Triassic (Mansa Guda Formation)

Shale, clay and siltstone, gray and red; some sandstone and ferruginous concretionary zones

Sandstone and quartz conglomerate.---

Sandstone, gray; some siltstone -.-.---

Claystone, greenish-gray

Sandstone, medium to coarse, gray;

some claystone

$126.6 \quad 158.6$

$3.1 \quad 161.7$

$33.6 \quad 195.3$

$15.2 \quad 210.5$

$30.5 \quad 241.0$

C-3684 near Wardeglo

Altitude 119 metres

Drilled in 1970

Lithologic character

Thickness Depth

(metres) (metres)

Pliocene (Merti Beds)

Clay, gray and red, sandy and pebbly;

pebbles of weathered granite and quartz

$90.0 \quad 90.0$

Clay, sand, and gravel .............

$12.2 \quad 102.2$

Clay and sand, fine to very coarse .....-

$\begin{array}{ll}7.7 & 109.9\end{array}$

Sand and gravel; quartz pebbles up to

$10 \mathrm{~mm}$, subrounded

$9.2 \quad 119.1$

C-3686 near Aus Manduli

Altitude 404 metres

Drilled in 1970

Lithologic character

Thickness Depth

(metres) (metres)

Holocene and Pleistocene (?)

Clay, brown and reddish, with

ferruginous concretionary zones;

pebbles of weathered granite and quartz

$24.4 \quad 24.4$

Jurassic

Shale, siltstone, tan and yellow; thin layers of sandstone

Shale, gray, hard

$12.2 \quad 131.1$

Shale, gray, hard; interbedded thin 
TABLE 13.-Logs of selected boreholes in northeastern Kenya-Continued

C-3690 near Mansa Guda

Altitude 519 metres

Drilled in 1970

Lithologic character

Thickness Depth

(metres) (metres)

Holocene and Pleistocene (?)

Clay, red, sandy and pebbly

$12.2 \quad 12.2$

Triassic (Mansa Guda Formation)

Shale, gray, and quartzite

conglomerate

$6.1 \quad 18.3$

Sandstone and conglomerate; some

shale

$21.4 \quad 39.7$

Sandstone and conglomerate

$15.2 \quad 54.9$

Siltstone and clay ironstone

$3.1 \quad 58.0$

Sandstone, siltstone, and shale

$30.5 \quad 88.5$

Sandstone and conglomerate; some siltstone

$94.5 \quad 183.0$

\section{C -3697 southwest of Meri}

Altitude 156 metres

Drilled in 1970

$$
\text { Lithologic character }
$$

Thickness Depth (metres) (metres)

Holocene and Pleistocene (?)

Clay, sandy, gray

$6.1 \quad 6.1$

Pliocene (Merti Beds)

Clay, gray, red, and brown, sandy ;

pebbles of weathered igneous rocks ..

Sand, fine to coarse; some gray clay ...

Clay, red, sandy

$137.2 \quad 143.3$

$6.1 \quad 149.4$

$33.6 \quad 183.0$

\section{C-3727 northwest of Meri}

Altitude 174 metres

Drilled in 1971

Lithologic character

$\begin{array}{lc}\text { Thickness } & \text { Depth } \\ \text { (metres) } & \text { (metres) }\end{array}$

Holocene

Sand, clayey, reddish-tan

$3.1 \quad 3.1$

Pliocene (Merti Beds)

Clay, gray and red, sandy; pebbles of quartz and igneous rock; thin layers of sandstone

Sand, fine to coarse; some clay

$39.6 \quad 149.4$

Clay, gray, hard, slightly sandy

$18.3 \quad 167.7$


TABLE 13.-Logs of selected boreholes in northeastern Kenya-Continued

C-3805 near Sericho

Altitude 239 metres

Lithologic character

Holocene and Pleistocene

Clay, grayish-brown, hard ........--

Clay, brown, sandy

Clay, grayish-brown, hard

Drilled in 1972

Clay, gray and brown, sandy

Clay, gray and brown, sandy and pebbly

Thickness Depth

(metres) (metres)

Sand and gravel; pebbles of quartz,

igneous and volcanic rock, up to

$30 \mathrm{~mm}$ diameter

$1.8 \quad 1.8$

$4.0 \quad 5.8$

$6.1 \quad 11.9$

$19.2 \quad 31.1$

$\mathbf{1 7 . 7} \quad \mathbf{5 8 . 8}$

$3.1 \quad 51.9$

Pliocene (Merti Beds)

Clay, gray and red, sandy

$39.6 \quad 91.5$

\section{C-3811 near Giriftu}

Altitude 299 metres

\section{Lithologic character}

Holocene

Sand, clayey, $\tan$

Drilled in 1972

Thickness Depth

(metres) (metres)

Pleistocene

Clay, tan and pink; calcareous nodules -

Pliocene (Merti Beds)

Clay, brown and tan, pebbly

$1.2 \quad 1.2$

$11.0 \quad 12.2$

$21.4 \quad 33.6$

Clay, sandy and pebbly; pebbles of quartz and weathered granite;

sandstone layers

Clay, brownish-gray; calcareous nodules and gneiss cobbles

$45.7 \quad 79.3$

$21.4 \quad 100.7$

Precambrian (Crystalline rocks)

Clay, with fragments of gneiss

$12.2 \quad 112.9$

Gneiss, biotite; slightly weathered

$15.8 \quad 128.7$

C-3814 near Sericho

Altitude 236 metres

\section{Lithologic character}

Drilled in 1972

Holocene and Pleistocene

Thickness Depth

(metres) (metres)

Clay, brownish-gray, hard, slightly

sandy - _.

Clay, gray, very hard, sandy -...-.-.-

Clay, gray and brown, sandy; thin layers of silt and sand

$5.8 \quad 5.8$

$2.8 \quad 8.6$

Sand, coarse, and gravel; pebbles of subrounded quartz, igneous, and

volcanic rocks

$35.7 \quad 44.3$

$\begin{array}{ll}1.6 & 45.9\end{array}$

Pliocene (Merti Beds)

Sand, clayey, brown

$6.1 \quad 52.0$


TABLE 13.-Logs of selected boreholes in northeastern Kenya-Continued

C-3820 northwest of Sabule

Altitude 143 metres

Drilled in 1972

Lithologic character

Thickness Depth

(metres) (metres)

Pliocene (Merti Beds)

Sand, reddish, and fine gravel;

calcareous nodules

Sand, fine to very coarse, light tan;

some fine gravel of quartz and

weathered igneous pebbles; some clay

and silt

$107.3 \quad 116.5$

Sand, fine, silty and clayey, brown -.--

Sand, fine to coarse; some fine gravel.-

Sand, very fine to medium, tan .......

$8.3 \quad 124.8$

$6.4 \quad 131.2$

$3.7 \quad 134.9$

\section{C-3821 southeast of Sabule}

Altitude 139 metres

Drilled in 1972

Lithologic character

Thickness Depth

(metres) (metres)

Pliocene (Merti Beds)

Sand, coarse to very coarse, red ......-

6.1

Sand, fine to coarse, reddish-brown; some gravel and calcareous nodules..

Sand, fine to coarse, tan, silty and clayey; layers of gravel; pebbles of quartz and weathered igneous rock -

Clay, grayish-brown, slightly silty and pebbly

\section{$6.1 \quad 12.2$}

$70.1 \quad 82.3$

$12.2 \quad 94.5$

Sand, fine to very coarse, tan; some gravel and ferruginous clay

$6.2 \quad 100.7$

Clay, grayish-brown, pebbly

$9.2 \quad 109.9$

Sand, fine to very coarse, tan; some gravel and clay

$21.2 \quad 131.1$

Silt, light tan; small amount of sand .-

Sand, very fine to coarse; some very fine gravel; trace of silt

Sand, fine to coarse, and pebbly clay.-.-

$10.7 \quad 147.9$

$11.3 \quad 159.2$ 
TABLE 13.-Logs of selected boreholes in northeastern Kenya-Continued

C-3850 near El Wak

Altitude 445 metres

Drilled in 1972

Lithologic character

Thickness Depth

(metres) (metres)

Holocene

Soil; silt, sandy, red

1.5

Pleistocene (El Wak Beds)

Limestone, white; thin layers of arenaceous limestone, red and brown

Cretaceous

Shale, greenish-gray; calcareous nodules

$\begin{array}{rr}45.7 & 70.1 \\ 6.1 & 76.2 \\ 18.3 & 94.5 \\ & \\ 24.4 & 118.9 \\ 12.2 & 131.1\end{array}$

\section{C-3866 near Tuli Roba}

Altitude 509 metres

Drilled in 1972

Lithologic character

Thickness Depth

(metres) (metres)

Holocene

Clay, grayish-brown, slightly sandy, hard

Precambrian (Crystalline rocks)

Clay, sand, fragments of gneiss;

strongly weathered crystalline rocks.-

36.6

39.7

Amphibolite, weathered

45.7

85.7

Amphibolite, unweathered

$67.1 \quad 152.5$

C-3902 near Liboi

Altitude 102 metres

Lithologic character

Drilled in 1973

Thickness Depth

(metres) (metres)

Holocene

Clay, gray, hard

$6.1 \quad 6.1$

Sand, fine to medium, gray

$6.1 \quad 12.2$

Pliocene (Merti Beds)

Clay, gray; thin layers of sand; calcareous concretionary zones

$24.4 \quad 36.6$

Sand, medium to coarse, clayey; some gravel

$30.5 \quad 67.1$

Sand, coarse, and gravel _..........

$15.2 \quad 82.3$

Sand, fine to coarse, clayey

$6.1 \quad 88.4$

Sand, coarse, and gravel

$15.2 \quad 103.6$ 


\section{INDEX}

[Italic page numbers indicate major references]

A Page

Aberdare Range

N8, 16

Acacia trees

Acknowledgments

Airports

Alinjugul _...... $33,37,56,58$

Alluvium _............... 21, 34, 40

Aquifer, confined ..... 30, 35

water table ........ 33

Arabía - .

Archers Post _........... 16, 17, 18

Asahaba _.................... 27, 42, 54

Aus Manduli ............... 26, 29, 54,60

B

Banissa Beds

Basement complex _.... 6, 21, 22, 24, 25, 29, 42

Bata

43,56

Benane -...... 7, 8, 40

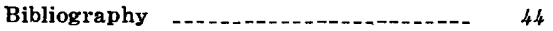

Borehole, usage defined ............ 2

Buna -

Bur Mayo $22,25,26$

\section{C}

Catchments, natural and artifical

Climate

dry season

Commiphora bushes

Contacts, Jurassic-Cretaceous _..._._. 23, 27

Jurassic-Pleistocene _........... 38

Precambrian-Triassic _............ 22

Tertiary-Quaternary _........... 23

Triassic-Jurassic ............. 22, 26

Triassic-Tertiary

Craelius East African Drilling Company

Cretaceous rocks

borehole records

water quality

water-bearing potential

Crops -..-- -

Crystalline rocks _._._._._. 24, 25, 29

Cultural features

\section{D}

Dadaab

$6,8,31,35,36,37,56,58$

Dambas

$26,52,54$

Dams

18

Danissa Beds

23,27

Darken

$36,37,56$
Daua Limestone Series _............. 22, 26

Page water-bearing potential

Depositional environments, arid to

semiarid - 24

continental

deltaic _._._. 27,35

estuarine -....... 27

lacustrine, Pleistocene ......... 28, 38

lagoonal -......... 23

marine

Derkali _.

Didimtu _.......... 26

Discharge, annual, monthly, Ewaso

Ng'iro _...... 16, 18

inștantaneous, delayed _......... 17

Dololos -

Drainage ........... 6

Drought _..... 12, 38

E

East African Meteorological Department 13 Economic development _... 2

El Dera _...

El Wak _............. 6, 14,22, 23, 26,

$27,28,37,40,54,64$

El Wak Beds .............. 23, 37, 39, 40,64

El Wak Township _..... 50

Electrical resistivity surveys _....... 43

Evapotranspiration _........... 8, 32, 34

\section{F}

Fan deposits

Faulting _... 22, 28

Fino _......... $7,26,27,42,54$

Folding _....... 22

Freshwater, zones

\section{G}

Garba Tula

$19,20,28,29,40$

Garissa _......... 6, 9, 11, 13, 14, 15, 42, 56

Garissa District _.... 6, $7,8,9,12,13,14,15$, $18,23,28,29,32,43,48$

Geographic features _..... 6

Geographic names, usage defined ...... 2

Geologic formations .............. 21

Giriftu _...... $6,14,23,24,25,50,52,56,62$

Ground water, availability .......... 42 bodies, perched ....... $32,34,40$ saline 


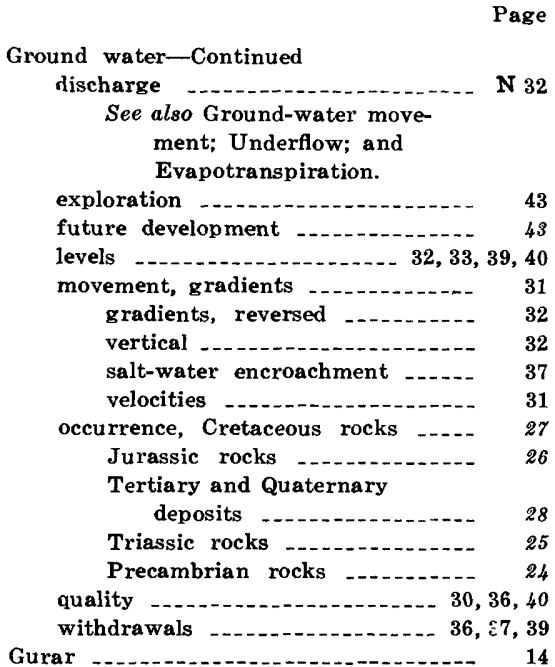

\section{H}

Habaswein $6,14,16,17,18,20,28,29,30$, $31,33,34,35,36,37,41,56,58,59$

Hadado

Hagadera

Halati 34,58

Holocene deposits

24,52

Humphries and son 23,40

Hydraulic conductivities, Merti aquifer

I

Indian Ocean

$7,8,32,42$

Inselbergs $6,7,21$

International Bank for Reconstruction and Development (World Bank)

International Development Association

Introduction

Intrusive rocks

Isiolo District 34,50

\section{$\mathbf{J}$}

Jurassic rocks, borehole records extent source rocks thickness

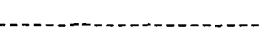

water quality water-bearing potential

\section{$\mathbf{K}$}

Kalalut $31,36,37,56,58$

Kenya, Ministry of Agriculture Ministry of Agriculture, Range Management Division Water Department 13 Geological Survey Ministry of Works, Hydraulic Branch
Khot Khot

Page

Kiunga

N 29, 31, 56

Kolbio

$7,9,11$

32,56

Lamu - 8

Lava flows .

water-bearing potential _.......... 28

Liboi _............... 6, 8, 29, 30,31,32,

Lithologies:

$33,37,56,58,64$

Clays

34,35

Concretionary zones ....... 24, 29, 38, 43

Gravel _............. 28, 29, 32, 35

Gypsum _............. 26, 38, 39

Lateritic zones -....- 28

Limestone _.............. 26, 27, 39

Sand -............ 32

Livestock management ................ 2, 4

Livestock population -.... 14

Location of area

Lorian Swamp _...... 8, 16, 17, 18, 30, 31, 33, $34,35,37,40,41,43,58$

\section{M}

Mado Gashi _- 6, 8, 14, 20, 28, 34, 37, 40, 56, 58 Mandera _............ 9, 11, 14, 15, 27, 40, 56 Mandera District ..... 6, 7, 9, 14, 15, 18, 23, 26, $27,28,37,42,48$

Mandera Series

water-bearing potential ............. 26

Mansa Guda .................. 25, 26, 54,61

Mansa Guda Formation ....... 22, 26, 60,61 water-bearing potential .......... 25

Marehan Series _... 23 water-bearing potential _......... 27

Marsabit District _........ 34

Meat production

Melka Bulfayo - 33

Meri _........ 17, 31, 35, 36, 37, 56, 58, 61 Merti _............ 16, 17, 23, 28, 33, 35, 41

Merti aquifer, hydraulic properties.. 30, 31, 43 saturated thickness .............. 32 water quality _....... $30,31,37,41,42$ Merti Beds ... 23, 24, 28, 29, 34, 35, 36, 38, 39, $40,58,59,60,61,62,63,64$ water quality ............. $30,31,36$

Metamorphic rocks _..._.

Miocene deposits ................ 23

Monsoons -

Mount Kenya _... 8, 16

Moyale _.................... 9, 11, 23

\section{$\mathbf{N}$}

Nanyuki _...

Northern Frontier District

Nyambeni Range

\section{P}

Paleozoic rocks _...

Pans _... 
Pleistocene deposits water quality

lava flows $23,28,34$

Pliocene deposits -..-_-_._- 23

Population _.................... 14

Potentiometric surface and heads,

Merti aquifer _..._ 30, 31, 32, 36

Precambrian rocks ........ 6, 7, 13, 21, 22, 29

borehole records _..._._._._._._. 52

stratigraphic logs _............ 62,64

water quality _............. $41,42,48$

water-bearing potential _.......-. 24, 42

Precipitation, individual records for pilot study area

Pleistocen

rainfall-runoff relations

Previous investigations

\section{Q}

Quadrangle sheets

Quaternary deposits

alluvial, thickness

water quality

$\mathbf{R}$

Radiocarbon analyses

Railroad

Rainfall, average annual

average annual, near coast

average monthly

distribution, areally

seasonal

yearly

(1)

Recharge, localized _.............. 25

Merti aquifer ............. 32, 33, 34, 43

Wajir Beds - 39

Reservoirs _....... 4, 18, 19

evaporation _......... 21

seepage losses ........ 21

Riba -..... 38

Rivers and other drainageways,

Daua -

Ewaso $\mathbf{N g}$ 'iro -.- 7, 8, 16, 17, 18, 24, 29, 30, $31,33,34,35,38,40,41,43$

Galana Gof -

Laga Badoda

Lagh Bisigh

Lagh Bogal

Lagh Haro

Lagh Katulo

Lagh Sure

Lak Afwein

Lak Bogal

$24,28,35,40$

Lak Bor _...

Lak Dera -_- 7, 16, 29, 30, 31, 33, 35, 41, 43

Lak Dima

Lak Telangor -.... 35

Lak Tuglub _............. 19, 35

Tana River .......... 2, 8, 15, 23, 24, 40

through-flow -........ 7

Roads
Runoff N $16,19,39,40,42$

\section{$\mathbf{s}$}

Sabena _...

Sabena wells _...

Sabule _.......... 31, 35, 56, 58, 63

Saline water, zones

Sericho _._._._. 17, 31, 33, 34, 40, 41, 58, 62

Soils _.................... 13, 21, 24, 25, 28

calcium carbonate nodules

paleosols _........ 42

Specific capacities, Merti aquifer -....- $\quad 30$

Structural features, faults

folding - -

Mesozoic basin _........... 22, 26, 27

Surface water _._.

seepage losses -...- 33

storage

Swedish International Authority .....

$\mathbf{T}$

Takabba _........ $6,14,22,26,52,54$

Tanks -... 18

Tarbaj _...

Tarbaj Hill _......... 25

Temperatures, daily _........... 8 mean annual ............. 8

Terraces _...

Tertiary deposits _................. 22, 23

water-bearing potential _..._..... 28

Topography _...

Transmissivities, Merti aquifer ...... 30

Triassic rocks, borehole records ...... 54

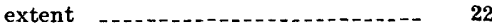

source rocks _...... 29

stratigraphic logs _.......... 60,61

thickness _..... 22

water quality _................... 48

water-bearing potential

Tritium determinations _.......... 36

Tuli Roba

\section{$\mathbf{U}$}

Underflow $\ldots \ldots \ldots \ldots . \ldots 32,33,34,39,40$

U.S. Agency for International

Development ......... 4

\section{$\mathbf{V}$}

Vegetation _........

Volcanic rocks _...

\section{W}

Wag Halla _...

Wajir .... $7,9,11,12,13,14,15,22,23,25,26$, $28,29,33,37,38,39,42,54,56$

Wajir Beds _................ 23, 37, 38

water quality -........ 39

Wajir Bor ........ 26, 38, 50, 54

Wajir District _........... 6, 7, 8, 9, 14, 18 ,

$23,26,28,48,50$

Wajir Township _... 50

Wardeglo _....... 56,60

War Gedud 


\begin{tabular}{|c|c|}
\hline Page & Page \\
\hline Water, sodium chloride type & Wells-Continued \\
\hline Waterlogging - & number drilled \\
\hline Weathering, calcium carbonate nodules. & number in Wajir area \\
\hline concretionary zones & yields, Cretaceous rocks \\
\hline in situ & El Wak Beds \\
\hline solution cavities $\ldots \ldots \ldots, 38,42$ & Jurassic rocks \\
\hline zone & Precambrian rocks \\
\hline Wel Garas - & Tertiary and Quaternary \\
\hline Wells, depth to water $\ldots 25,30,35,36,38,40$ & deposits \\
\hline drilling organizations & Triassic rocks \\
\hline
\end{tabular}

